\title{
The Tuma
}

\section{Underworld of Love}

Erotic and other narrative songs

of the Trobriand Islanders

and their spirits of the dead

\section{Gunter Senft}


The Tuma Underworld of Love 


\section{Culture and Language Use}

\section{Studies in Anthropological Linguistics}

CLU-SAL publishes monographs and edited collections, culturally oriented grammars and dictionaries in the cross- and interdisciplinary domain of anthropological linguistics or linguistic anthropology. The series offers a forum for anthropological research based on knowledge of the native languages of the people being studied and that linguistic research and grammatical studies must be based on a deep understanding of the function of speech forms in the speech community under study.

For an overview of all books published in this series, please see http://benjamins.com/catalog/clu

\section{Editor}

Gunter Senft

Max Planck Institute for Psycholinguistics,

Nijmegen

\section{Volume 5}

The Tuma Underworld of Love. Erotic and other narrative songs of the Trobriand Islanders and their spirits of the dead by Gunter Senft 


\section{The Tuma Underworld of Love}

Erotic and other narrative songs of the Trobriand Islanders and their spirits of the dead

Gunter Senft

Max Planck Institute for Psycholinguistics

John Benjamins Publishing Company

Amsterdam / Philadelphia 
The paper used in this publication meets the minimum requirements of American National Standard for Information Sciences - Permanence of Paper for Printed Library Materials, ANSI z39.48-1984.

\section{Library of Congress Cataloging-in-Publication Data}

Senft, Gunter, 1952-

The Tuma underworld of love : erotic and other narrative songs of the Trobriand islanders and their spirits of the dead / Gunter Senft.

p. cm. (Culture and Language Use, ISSN $1879-5838 ;$ v. 5)

Includes bibliographical references and index.

1. Kiriwinian language. 2. Trobriand Islands (Papua New Guinea)--Languages. I. Title. PL6252.K5 $48 \quad 2011$

499'. --dc23 2011026146

ISBN 9789027202871 (Hb; alk. paper)

ISBN 9789027284693 (Eb)

(C) 2011 - John Benjamins B.V.

No part of this book may be reproduced in any form, by print, photoprint, microfilm, or any other means, without written permission from the publisher.

The e-book edition of this book is made available under a CC BY-NC-ND 4.0 license. http://creativecommons.org/licences/by-nc-nd/4.o

John Benjamins Publishing Co. · https://benjamins.com 
Pela tommota Tauwema 


\section{Table of contents}

Acknowledgments

Introduction

XIII

\section{CHAPTER 1}

Death on the Trobriand Islands and the Trobriand Islanders' belief in a "baloma" spirit

1.1 Death on the Trobriand Islands 1

1.2 The Trobriand Islanders' belief in a "baloma" spirit 7

\section{CHAPTER 2}

The spirits of the dead and their underworld life on Tuma Island:

Trobriand eschatology

2.1 A baloma on his way to Tuma and his encounter with Topileta 15

2.2 How the newcomer is welcomed by the other baloma in the Tuma underworld $\mathbf{1 8}$

2.3 The life of the baloma in their Tuma underworld and their qualities 21

2.4 The baloma visiting their former villages during the harvest festivals 25

2.5 From baloma to spirit child: The Trobriand myth of conception 31

2.6 Eschatological concepts elsewhere in the Massim area and in the Pacific

\section{CHAPTER 3}

\section{The wosi milamala}

3.1 The biga baloma variety of Kilivila and the wosi milamala 43

3.2 Dance magic 48

3.3 The wosi milamala $\mathbf{5 1}$

3.3.1 Wosi Bweyava - Song of the yava flower (?) 52

3.3.2 Wosi Omnuyobu - Song of Omnuyobu 56

3.3.3 Wosi Oruvekoya - Oruvekoya Song 62

3.3.4 Wosi Verai 64

3.3.5 Wosi Onegava - Song of the Canoe Onegava 68

3.3.6 Wosi Pilugwana - Song of the canoe Pilugwana 72

3.3.7 Wosi Dorai - Song of the canoe Dorai 74

3.3.8 Usi Veponu 76

3.3.9 Usi Veto'i 77 
3.3.10 O Punatina - In Punatina 81

3.3.11 Wosi Bwebwe'una - Song of the village Bwebwe'una $8 \mathbf{8 2}$

3.3.12 Usi Vekota $\mathbf{8 2}$

3.3.13 Butugu - My Song/My Renown 83

3.3.14 Bweyega - The village Bweyega 84

3.3.15 Wosi Dubeyara - Song of the village Dubeyara 85

3.3.16 Wosi Dube’oli 86

3.3.17 Wosi Yéula 90

3.3.18 Wosi Oluvekoya-Oluvekoya Song 90

3.3.19 Wosi Opesi / Wosi Diyapani - The Office Song / The Song of the Japanese 94

3.3.20 Wosi Diyapani - The Song of the Japanese 97

3.3.21 A few final remarks and comments on form and content

CHAPTER 4

The moribund language of the spirits of the dead and its consequences for the Trobriand Islanders' culture

APPENDIX I

Pertinent quotes from

Frazer, James G. 1913. The belief in immortality and the worship

of the dead. Vol. 1. The belief among the Aborigines of Australia, the Torres Straits Islands, New Guinea and Melanesia. London: Macmillan. [http://www.archive.org/details/beliefinimmortal00frazuoft]

APPENDIX II

Metadata for the Wosi Milamala decumented on audio- and video-tape

References

Index 


\section{Acknowledgments}

This book is the result of almost 30 years of researching the language and culture of the Trobriand Islanders in Papua New Guinea. Writing this book would have been impossible without the help of many people and institutions. First I would like to thank the Deutsche Forschungsgemeinschaft (DFG: Ei-24/10-1-5; Se-473/2-1-2), especially Ursula Far Hollender and Manfred Briegel; the Research Unit for Human Ethology of the Max-Planck-Society and its director Irenäus Eibl-Eibesfeldt; and the Cognitive Anthropology Research Group (now: Department of Language and Cognition) at the Max-Planck-Institute for Psycholinguistics and its director Stephen C. Levinson for their support during and after my field research.

The technical group of the MPI for Psycholinguistics, especially Reiner Dirksmeyer, Paul Trilsbeek, and Ad Verbunt made it possible to combine the data presented in this book with the Internet access to the original audio and video documents. I very gratefully acknowledge their excellent cooperation.

I thank Irenäus Eibl-Eibesfeldt for allowing me to make his films on "milamala" dances (E 3129 and E 3130) also available on this website.

I thank Michael Dunn for providing the adequate software for making the maps and Peter Nijland for editing them according to my wishes.

I am also indebted to my colleagues at the MPI for Psycholinguistics for the general stimulating atmosphere of research.

I especially thank Eric Venbrux for his detailed, insightful and extremely helpful comments on the first draft of this book and recommendations for further reading. I am also very much indebted to Bettina Beer, Andrea Bender and Kirsty Gillespie for their detailed comments on this first draft of the monograph.

I want to thank Pieter Seuren for checking my English translations of the wosi milamala. I thank Eric Auer, Ingjerd Hoem, Verena Keck and Jürg Wassman for comments on the first version of this volume and Joe Blythe for pointing out the work of Allan Marett to me.

I want to thank my wife Barbara for her patience and perseverance in discussing my research with me, criticizing it, and living and working with me in the field in 1983 and in 1989. I would also like to thank our children very much for their understanding that their father almost annually left the family to do his field research and for living with their parents in Tauwema in 1989. 
I thank the National and Provincial Governments in Papua New Guinea, the Institute for PNG Studies - especially Don Niles, and the National Research Institute - especially James Robins, for their assistance with, and permission for, my research projects.

I would also like to thank Serah Kalabaku and Rod Clark as well as Lydia Kalabaku for their generous support of my research and for their hospitality and friendship over the years.

I express my great gratitude to the people of the Trobriand Islands, and above all the inhabitants of Tauwema and my consultants for their hospitality, friendship, and patient cooperation over all these years. Without their help, none of my work on the Kilivila language and the Trobriand culture would have been possible. Therefore I dedicate this book to the people of Tauwema.

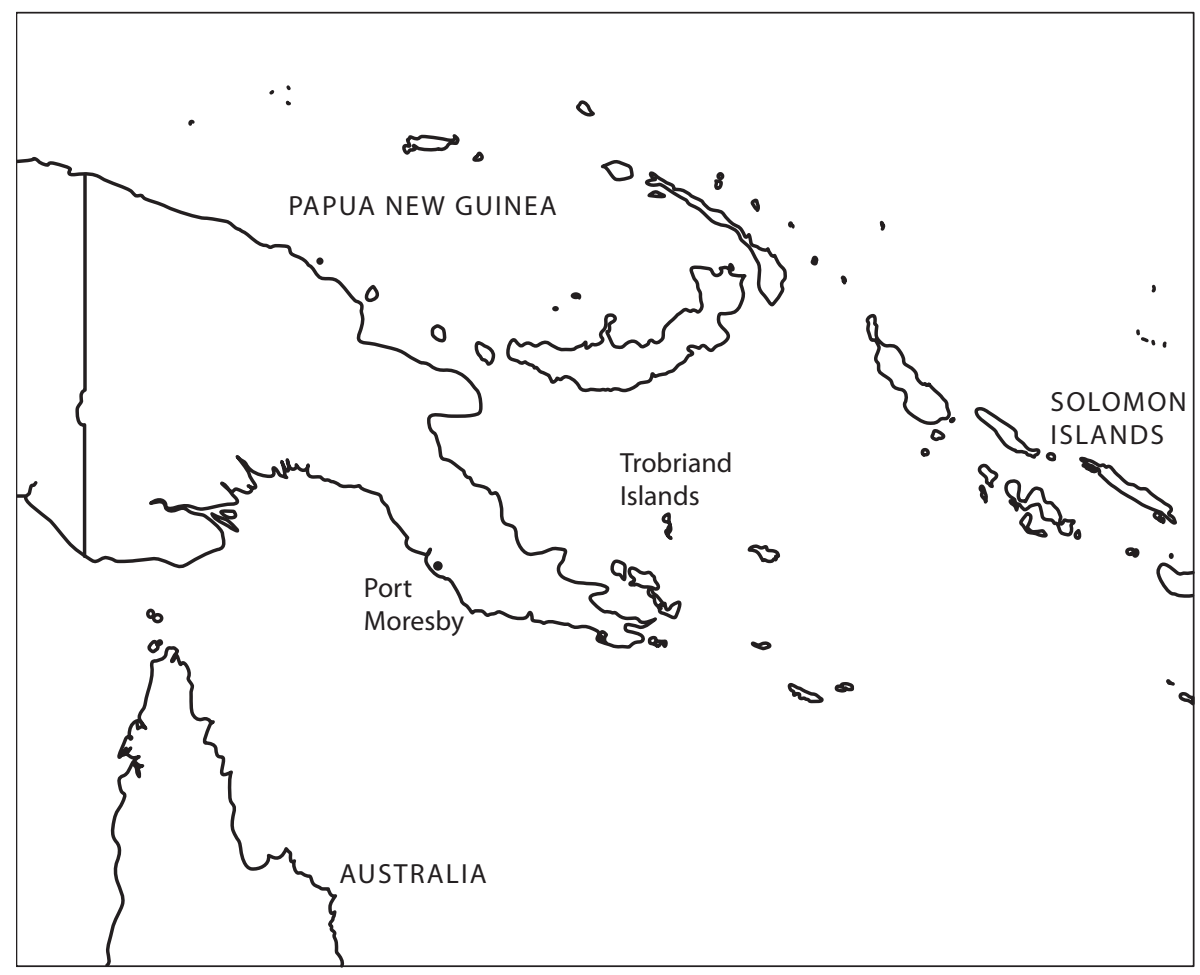

Map of Papua New Guinea 


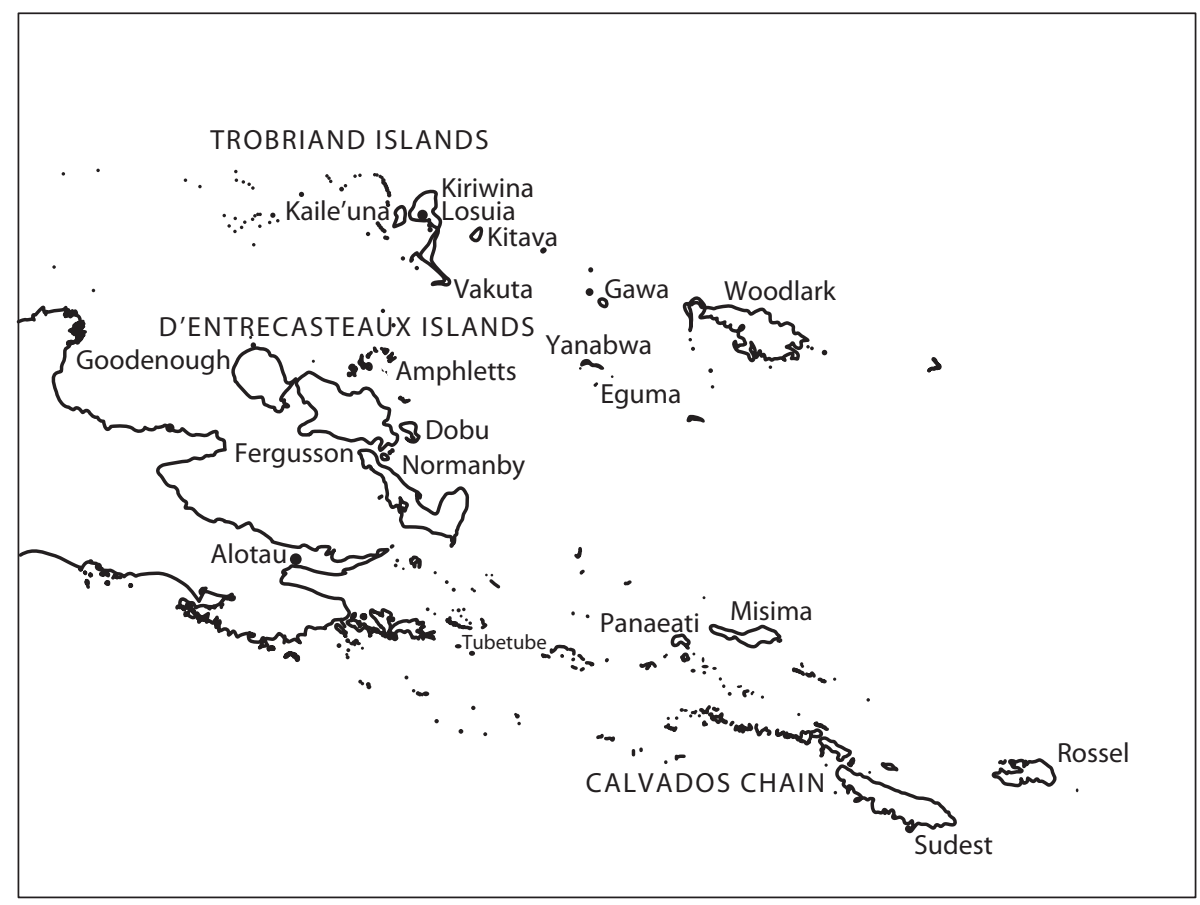

Map of the Massim area 


\section{xII The Tuma Underworld of Love}

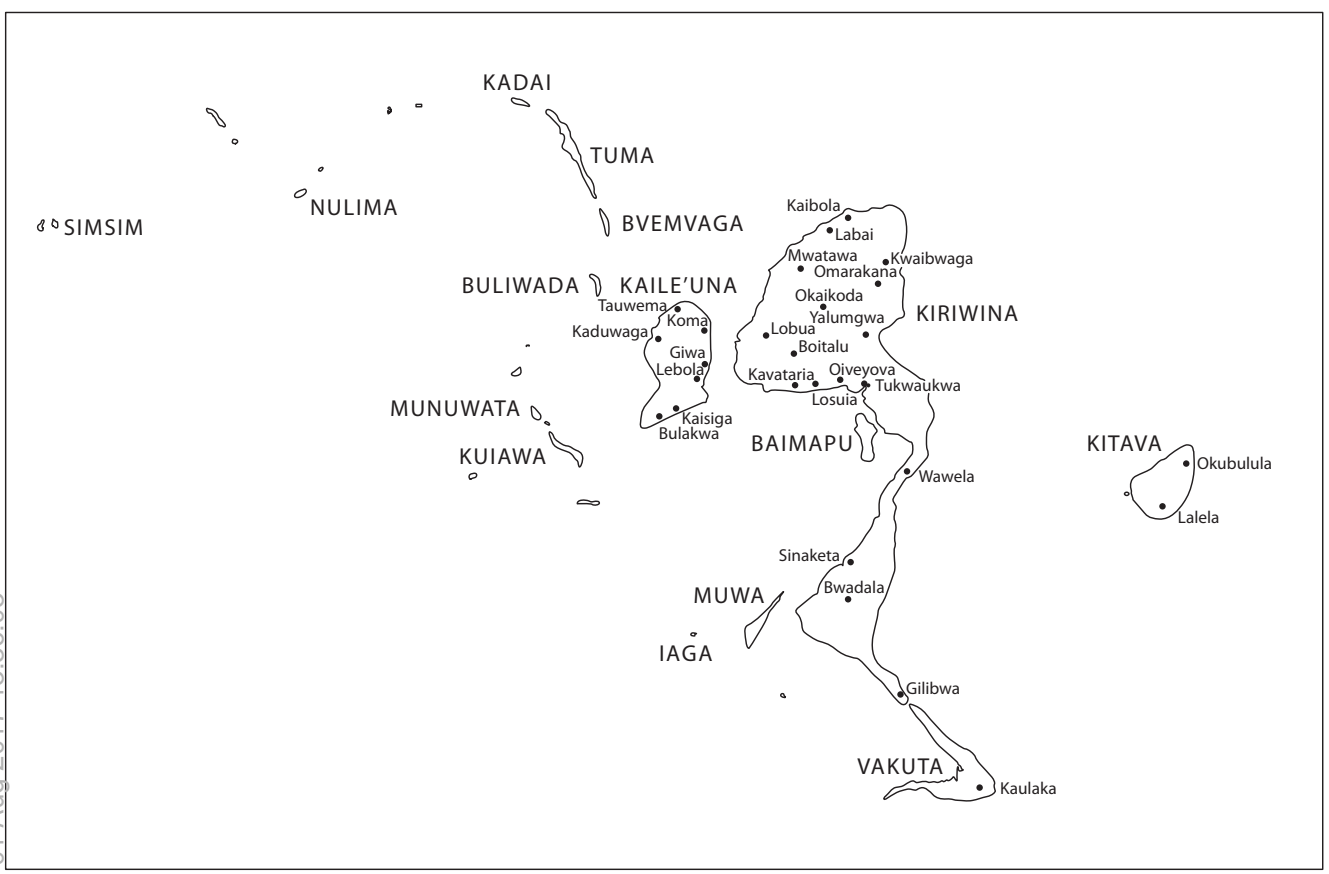

Map of the Trobriand Islands 


\section{Introduction}

Wosi Pilugwana

Vadenisa Bwiyariga

yakayobu yamvedoku.

Kapisina Kwe'ineoli

gidiviligu

Ne’oli.

Kumidorigu mweyuva mamidorim mweyuva vana-simgeori.

Sogu Yaurivori

ka’uvamapu -

maka'i

kakamapu mabwita.

Natokwabu ugwarai nukulibusa Pilugwana.

Kemyovau, ugwenegu bakana'ira o papala.
Song of the canoe Pilugwana

They go with Bwiyariga,

Yakayobu-herbs smell - and there's humming.

Pain is what Kwe'ineoli causes, the love magic, pain - and change in the course of time the love magic Neoli.

My hot spice -

how good is that, what a hot spice -

and sweet smelling herbs - very fresh.

Beloved Yaurivori

we meet each other -

words of love,

we exchange our wreaths of flowers.

Natokwabu goes there - she halts -

you push it out into the sea the canoe Pilugwana.

New canoe, my canoe -

soon I will lie on the outrigger platform.

Two weeks after I had arrived in the village Tauwema on Kaile'una Island, my place of residence ever since I started my research on the language and culture of the Trobriand Islanders in August 1982, I observed that a group of men convened at the village ground shortly before nightfall. Some of the men carried drums and stood in the centre of the group, while others gathered around them leaning on long polished wooden sticks. They smoked, chewed betelnuts, and chatted with one another. This congregation arose my curiosity. I grabbed my tape recorder and approached the group just when the drummers started to beat their drums intoning a very specific beat. I realized that they had three drums of different size, a small one which (as I later learned) is called katukenia, a middle sized one, the kupi, and a long one, the kesosau. Shortly after the drumming had started the drummers and the men who were standing around them first hummed a melody and then sang this melody producing different vowels, but not yet words. After 
this short phase in which the drummers and singers seemed to harmonize and synchronize with each other, one of the men started to sing a song (like the "Wosi Pilugwana" - "The song of the canoe Pilugwana" above) and the others joined him. They had obviously no objection to me tape-recording their songs and their music which sounded to me as if they came from another world. It was months later that I realized that this first impression was actually down to the point - at least from the Trobriand Islanders' point of view.

In the following 10 days or so this happened evening after evening, and I assumed that this was a kind of rehearsal for something special to come. And indeed, one morning after such a rehearsal the sounds of drums woke me up. I got up, brushed my teeth, grabbed my camera and my tape-recorder and ran to the village ground. What I saw was overwhelming (see also Eibl-Eibesfeldt \& Senft 1991:6):

Most men and some girls had dressed up carefully in their traditional clothes. The girls wore their so-called 'grass-skirts' that are made out of fibers of banana leaves. The men wore their traditional loin-cloth, made out of the bark of the betel-palm; however, in addition they also wore 'grass-skirts'. Most of the dancers had their faces decorated with asymmetrical ornaments in red, white and black colors. Their bodies were anointed with coconut oil and an essence made out of fragrant herbs and afterwards they had sprinkled their torsi with yellow blossom leaves. They all wore feathers of white cockatoos in their carefully combed hair and armlets made of natural fibers on their upper arms. Some of the dancers also wore necklaces made out of the red parts of the spondylus shell, tortoise-shell earrings and polished boars' tusks. Moreover, some men also had tied pandanus leaves around their ankles or wore belts made of small white kauri-shells around their waists, knees and/or foot-ankles. The drummers and singers with whom I was by now quite familiar had gathered at the centre of the village ground, they drummed and sang their songs, and the dancers danced in a circle around them. The other villagers were sitting on the verandas of their houses or on the platforms of the smaller yams houses and watched the performance.

I later learned that this was the opening of the "milamala", the Trobriand harvest festival - milamala literally translates as "become wealthy". ${ }^{1}$ People also told me that the songs were called "wosi milamala" - the songs of the harvest ritual. In the weeks to come the old men sang these songs quite often all night long - even after the actual "milamala" festival was officially ended. These performances (which

1. Malinowski (1935 Vol. II: 119) dares to make the "unscientific speculation ... [that] ... the word malia ... might be cognate with the Oceanic term mana". 
were not accompanied by dances any more) were called "kalibom", and they lasted till the end of October.

In January 1983, when I had made quite good progress in learning Kilivila, I wanted to use the rainy season - which kept most of the villagers at home - for transcribing the data I had collected during the last five months and for processing them for further analyses. I always worked with at least two consultants who controlled my transcriptions and helped me to gloss them. This was a relatively easy task until I started to work on the wosi milamala. My first impression was that I was dealing with a completely different language; moreover, it turned out that only a few mostly elderly men and women could isolate the words in these songs and produce them for me so that I could write them down (and as soon as I had done this I could also hear them in what seemed to me a sea of sounds before). However, my real problems started when I wanted to gloss them. All in all just 15 consultants were able to paraphrase the meaning of these words in ordinary everyday Kilivila; many of them had no teeth any more, so I often asked their children to work with me, my usual consultants and their father or mother to translate the documented songs. The elderly people first talked to their children who then repeated what was said to me; after that I tried to paraphrase the word's meaning in my own words - and this process continued until the old Tauwemians nodded with their heads, agreeing to my gloss (by the way, this tiresome procedure of transcribing and glossing wosi milamala did not change even when I could speak Kilivila fluently years after).

During these days of hard work the people of Tauwema realized that I was really interested in these songs, and after some hesitation they started to tell me more about them. I learned that the songs are sung in an archaic variety of Kilivila, which the Trobrianders called "biga tommwaya" - "the language of the old people, the language of the ancestors" and "biga baloma" - "the language of the spirits of the dead". The songs were not only sung during the milamala harvest festival and the "kalibom" period afterwards, but also - and with much more importance after the death of a Trobriand Islander and during the first mourning ceremonies. The Trobrianders believe in an immortal spirit - the "baloma". The vast majority of the wosi milamala describe the carefree 'life' of the spirits of the dead in their "underworld paradise" on Tuma, one of the Trobriand Islands.

Thus, before I can explain why the songs I documented in 1982 were sung during the harvest festival and before I can say anything about the contents of these songs and their cultural impact, we need to know more about the Trobrianders and their language in general and about their belief in a life after death in particular.

The Trobriand Islanders belong to the ethnic group called 'Northern Massim'. They are gardeners, doing slash and burn cultivation of the bush; their most important crop is yams. Moreover, they are also famous for being excellent canoe 
builders, carvers, and navigators, especially in connection with the ritualized 'Kula' trade, an exchange of shell valuables that covers a wide area of the Melanesian part of the Pacific (see Malinowski 1922). The society is matrilineal but virilocal.

Kilivila (also: Kiriwina, Boyowa), the language of the Trobriand Islanders, is one of 40 Austronesian languages spoken in the Milne Bay Province of Papua New Guinea. It is an agglutinative language and its general unmarked word order pattern is VOS (Senft 1986). The Austronesian languages spoken in Milne Bay Province are grouped into 12 language families; one of them is labeled Kilivila. The Kilivila language family encompasses the languages Budibud (or Nada, with about 200 speakers), Muyuw (or Murua, with about 4,000 speakers) and Kilivila (or Kiriwina, Boyowa, with about 28,000 speakers); Kilivila is spoken on the Islands Kiriwina, Vakuta, Kitava, Kaile'una, Kuiawa, Munuwata and Simsim. The languages Muyuw and Kilivila are split into mutually understandable local dialects. Typologically, Kilivila is classified as a Western Melanesian Oceanic language belonging to the 'Papuan-Tip-Cluster' group (Senft 1986: 6).

To understand the Trobriand Islanders' belief in a life after death we have to deal with death on the Trobriands, of course. In Chapter 1 I describe what happens shortly before and after Trobriand Islanders die until they are buried. Then I introduce the Trobriand Islanders' belief in the baloma spirit and in the Tuma underworld where these spirits live.

In Chapter 2 I give a comprehensive overview of the Trobriand Islanders' eschatology, that is their ideas about the end of things and their belief in some kind of existence after death. I first describe the journey of a male baloma from his village to Tuma and his encounter with Topileta, the "headman of the villages of the dead" (Malinowski 1974 [=1916]: 156). Then I report what the Trobrianders believe to happen when the new baloma is greeted by the other spirits of the dead. After that I characterize the life and the qualities of the baloma and present the myths that explain why they no longer live together with their relatives in the villages; why they are invisible now and why they only visit their old villages once a year during the milamala festival. Then I report on what happens, according to the Trobriand Islanders' belief, when a baloma wants to be reborn. The chapter ends with a comparison of these eschatological beliefs with eschatological concepts elsewhere in the Massim area and in the Pacific.

Chapter 3 first characterizes the wosi milamala together with the biga baloma variety of Kilivila in which these songs are sung and then presents the songs that I could document over the last 30 years of my field research on the Trobriand Islands. The songs are transcribed, translated and annotated.

Chapter 4 discusses the former role of these songs for the Trobriand Islanders' culture and their construction of their social reality and the impact of the fact that the biga baloma has become moribund in the last 20 years or so. 
Appendix I presents pertinent quotes from Frazer (1913) and Appendix II presents the metadata for the Wosi MIlamala documented on audio and video-tape.

The interested reader of this book has the opportunity to access the internet and listen to most of the original data presented in Chapter 3. Three of the songs are also video-documented. The films E 3129 and E 3130 by Irenäus Eibl-Eibesfeldt (see Eibl-Eibesfeldt \& Senft 1991) document wosi milamala and milamala dances. The data can be found under the following URL: http://www. mpi.nl/people/senft-gunter/research. In order to access the recordings, please make sure you have a modern browser (a recent version of Firefox, Opera, Internet Explorer or Safari), a recent Java (JRE) plugin and the QuickTime plugin (at least version 7). Given the fact that some of the stanzas were sung at different times, the website unfortunately cannot mirror the structure of Section 3.3. Therefore it is compulsory to first read the metadata description that goes with each of these audio- and/or video-documents (see also Appendix II). I will refer to the URL after the transcriptions of each of the song cycles.

Unfortunately I am not able to transcribe the melodies of the documented songs. I hope that these very specific songs and the atmosphere they create may excite the interest of a music ethnologist who will use the openly available data for a music ethnological study of the "wosi milamala". 


\section{Death on the Trobriand Islands and the Trobriand Islanders' belief in a "baloma" spirit}

During my long term field research on the Trobriands I observed three cases of death. On the 28th of May 1983 Gionavana, a young man of 19 years of age and a member of the highest ranking Malasi clan, ${ }^{2}$ had died in Koma, one of the neighbouring villages of Tauwema (see Senft 1985), on the 11th of July 1989 Moligala, a man in his late seventies, had died in Tauwema, and on the 3rd of June 1997, Mwasei, a highly respected and influential man in his late sixties, had died in Tauwema. All three men were members of the Malasi-clan. In what follows I describe what happens before and while somebody is dying and what happens immediately afterwards. ${ }^{3}$ After this description I present the Trobriand Islanders' belief in a "baloma" spirit and in an underworld land of the baloma.

\subsection{Death on the Trobriand Islands}

The ways of how relatives are supposed to accompany a dying person are still traditionally prescribed. The aim of all these acts is to safely conduct the balomaspirit into the Tuma underworld and to secure the spirit's happy existence there (see Malinowski 1963a: 257f.). Dying persons are lying in their houses on a woven mat made of dried pandanus leaf fibers ( $m o i)$, wearing their bodily decorations and their best traditional clothes - in the case of a man a loin-cloth (mwebua)

2. The Trobriand clan hierarchy consists of four clans with the Malasi clan as the socially highest ranked clan followed by the Lukuba clan, the Lukwasisiga clan, and finally the Lukulabuta clan. All four clans also differentiate between named subclans.

3. Bronislaw Malinowski (1929, 1974:48-53 \& 60-63 [=1926a]) and Annette Weiner (1976, 1978,1980 ) have described dying, mourning and mortuary ceremonies on the Trobriands in great detail. See also Damon and Wagner (1989). The description presented here is based on my own field work experience on the Trobriands. 
made of the bark of a betel-palm tree ${ }^{4}$ or a modern colorful waistcloth made of cotton, in the case of a woman a traditional grass-skirt (doba) made of banana and pandanus leaves or a modern skirt. Dying persons are covered with flowers and their most precious possessions (see Senft 1985:473). Fruit, prepared dishes, water and tea are at hand in case they want to eat or drink something. Up until lately messages were given to dying persons for relatives or friends who had died before. When night falls, other villagers congregate in front of the dying person's house, sit down on mats and sing milamala songs - all night long with just short intermissions. When the relatives in the house realize that death is approaching their beloved one, they embrace him or her, rub the body with valuables (vegua), anoint the body with coconut oil (bunami), paint her or his face with the red mixture of betelnut and lime (soba) and comfort him or her verbally. When death finally occurs, the relatives throw themselves on the corpse and break out in loud wailing. Malinowski (1963a: 258) describes this moment as follows:

They are seized, as it were, with a frenzy of ritualized sorrow ... But all this is ordered, foreseen, determined by tradition ... it is all spiritually significant and morally effective. It helps the survivors, and it helps the spirit of the dead.

After a while people who are not related to the deceased fill the corpse's bodily apertures with coconut husk fibers, tie its legs together and bind its arms to the sides. After that they carry the corpse on the mat outside of the house to the platform of the small yams-house (bwema) that belongs to the deceased or one of her or his friends - if the person had died during the night, this is done when day breaks. They lay out the corpse in state with betelnuts on strings criss-crossing the torso of the deceased and with all her or his most important valuables at her or his side and on the body. All these actions are taboo to the relatives of the deceased. Soon the deceased person's closest friends climb on the platform and sit at both sides of the corpse. The parts of the yams house at the head and at the feet of the deceased remain free so that other mourners who gradually approach the scene can have a last look at her or him or bend themselves over him or her in their grief or even briefly hold and cradle the corpse's head in their lap. From time to time the friends of the deceased intone and sing stanzas of different milamala songs.

Soon many mourners arrive - even from other nearby villages - after having heard of the case of death; they ritually cry for the deceased by literally weeping barrels. After a few minutes of loud and uncontrolled crying they retreat to the platforms of other small yams houses in the vicinity or to relatives who live in

4. The scientific name of the betelpalm or arecanut tree and its nuts is areca catechu. 
the village of the deceased, sit down there, start gossiping and closely observe the newcomers and their mourning behaviour.

At the same time kinsmen of the deceased bring yam tubers from the garden to the village, pile them up, scrape some of them and start boiling them; sometimes even one or two pigs are slaughtered, cut into pieces and cooked. This food will later be distributed among the persons who helped adorning and laying out the corpse. This small distribution ceremony (sagali) is called puya.

In the meantime the deceased person's surviving parents, siblings, widow or widower and children (insofar people in these categories of the bereaved exist) congregate at the village yard. They do not wear body decorations at all but special clothes - in the case of Gionavana's death in 1983 his father wore a green loincloth (yagapwa) made of the leaf of a specific pandanus tree, and his mother and sister wore the grass-skirt they only use when they have a bath or are doing the laundry (sepwana) - and bewail their beloved one in a loud, monotonous and stereotypical way. The surviving parents and siblings usually carry personal belongings of the deceased, like for example a bag, a comb, the sleeping mat, or a towel. This special group of mourners bewail their beloved one with ritualized formulae, like for example the following so-called 'kasolukuva' formula which I recorded in 1983. They also perform a kind of dance (the so-called vesali dance) while uttering these formulae. The mother and the sister of the deceased Gionavana praised him as a hard worker and excellent gardener (see also Gillespie 2010: Chapter 4). These formulae may be repeated over and over again (see Senft 1985:485); they are intense expressions of deep grief in a situation prevailed by communal crying and lamentations. Gionavana's mother bewailed her son as follows:

Natugu, natugu, latuge gwadegu, tuda, toka'utu, tokabobu, toveyami, tomigile'u, igadegu, Gionavana, tokwebagula tokanoku, tobwetukula,

igadegu, latugu,

ulu bwetuduva, ulu bweka'utu, ulu bwekabobu, ulu bwetata $i$, e, igadegu, Gionavana, e...

His sister recited this formula:

Akoveaka, lugute, akoveaka, agu kobau, agu kogugula ulisiyela, ulitabe'u, agu kema. Luguta, kaipe’ula
My child, my child, my child, they cry, my child, fine figure of a man, intelligent man, decorated man, honest man, it hurts me, Gionavana, best gardener, man with many garden plots, hard working man, it hurts me, my child, my beautiful son, my dear child, my caring child, my well educated son, ih, eh, it hurts me, Gionavana, eh...

My strong fire, my brother, my strong fire, my big heap [of yams], my heap of food, my everything, my collector of food, my axe. My brother, strong, 
kaimatua, kaitabwau - Gionavana $o$, bwadage, $a, a, o, o, e, e$, oh, bwadagu, bwadage, $o, o, u, u \ldots$ vigorous, mighty - Gionavana my brother, ah, ah, oh, oh, eh, eh, my brother, my brother, oh, oh, uh, uh...

Simpler mourning formulae that are referred to as 'valam' - 'crying' usually refer to the mourner's kinship relation to the deceased (see Senft 2010a: 80f.).

Malinowski's (1929:128f.) observation about mourning on the Trobriands still holds:

The kinsmen of the deceased ... must keep aloof from the corpse. They are not allowed either to wash or adorn or fondle or bury it ... The kindred must also not display any outward signs of mourning in costume and ornamentation, though they need not conceal their grief and may show it by weeping. Here the underlying idea is that the maternal kinsmen (veyola) are hit in their own persons; that each one suffers because the whole sub-clan to which they belong has been maimed by the loss of one of its members. 'As if a limb were cut off, or a branch lopped from a tree.' Thus, though they need not hide their grief, they must not parade it... [T] he taboo against touching the corpse applies primarily to the members of the sub-clan and especially to the actual kinsmen, to whom, of course, the temptation to touch the corpse, as an expression of love, would be strongest.

Quite different, in the native idea, is the relation of the widow, and of the children [of a dead man] and relatives-in-law to the dead and to his corpse. They ought, according to the moral code, to suffer and to feel bereaved. But in feeling thus they are not suffering directly; they are not grieving for a loss which affects their own sub-clan (dala) and therefore their own persons. Their grief is not spontaneous like that of the veyola (maternal kinsmen), but a duty almost artificial, springing as it does from acquired obligations. Therefore they must ostentatiously express their grief, display it, and bear witness to it by outward signs. If they did not, they would offend the surviving members of the dead [person's] sub-clan.

Annette Weiner (1988:36f.) points out that the members of a deceased's clan are called "toliuli" which can be glossed as "owners of the dead person's things". It's them who organize the burial and the exchange ceremonies that follow (see below). Villagers from other clans who are related with the dead person patrilaterally or through ties of marriage are called "toliyouwa", which can be glossed as "workers". They are the public mourners.

If the deceased had died early in the morning, villagers who belong to the clan of the deceased soon start digging a grave at the outskirts of the hamlet, usually close to where the deceased lived. If the death occurred in the afternoon or at night, the grave will be dug in the morning of the next day.

Despite the rather profane cooking and grave digging activities and ongoing gossiping the atmosphere in the village is all in all quite depressing. 
After some hours of bewailing the corpse is taken back into his/her house. Now the mother and father of the deceased, her or his partner and children are allowed to enter the house, they loudly lament the loss of their beloved one, bow deeply in front of the corpse, ${ }^{5}$ bid their last farewell, leave the house again after a few minutes and continue to display their grief on the village yard (see Senft 1985: 479). Then male and female friends of the deceased who do not belong to the dead person's clan take away the best ornaments and valuables (vegua) from the corpse. As Moss (1925: 190) rightly states, this is still

... excused by some theory that the 'souls' only go to the spirit-land, as in the Trobriand Islands ..., where the corpse is carefully stripped of all valuables just before burial, while the soul carries them with him [or her] 'in their spiritual aspect' as a present for the guardian of Tuma.

The friends of the deceased also insert a betelnut into the corpse's mouth - the baloma of the deceased will need this nut to enter the Tuma underworld, as we will see later - bind its jaw close and roll mats around the body so that the corpse is completely covered. Then these mats are bound together with pandanus fibers.

When the grave diggers have finished their work, close friends of the deceased and neighbours carry the corpse to the grave and carefully and gently lay the corpse wrapped up in pandanus mats into the grave. ${ }^{6}$ In former times but also sometimes these days - an expert magician steps down into the grave and whispers magical formulae to protect the corpse against the munukwausiinvisible sorceresses or flying witches (Malinowski 1922, Chapter 10; 1974: 152f. [=1916]) - who are attracted by cases of death and are believed to try to feed on the corpse. After this rite of protection magic one of the persons who helped laying the corpse into the grave first places bigger coral stones around the corpse and carefully puts smaller stones and sand on top of it. Then sand is filled into the grave, and when the corpse is completely covered, the rest of the coral stones and the sand are shoved into the grave. Big coral stones are piled up on the grave so that they form a quadratic, up to one meter high kind of grave mound. This mound is decorated with flowers and sometimes even a small roof-like

5. These forms of paying respect are lexicalized in Kilivila as follows:

-temamila- to bow (to a chief, to a dead person);

- kululu- $\quad$ to honor someone, bowing deeply and bending one's knees;

-kavagina- to honor a chief or a dead person by crawling like a child in front of him (or her).

6. Up till the 1920s Trobrianders were buried with their feet pointing toward Tuma (see Connelly 2007: 137). 
construction is built to shelter the grave. The men who dug the grave, buried the deceased and made the grave mound then go in line to the nearest fresh water well and have a ritual cleansing bath.

Soon after the burial the villagers recongregate in front of the house of the deceased and after a while they sing milamala songs again. Some of them will remain there after sunset, keeping the death watch (yavali) all night long and singing milamala songs now and again. This death watch usually lasts for two days and nights. In the days of Malinowski - who did field research on the Trobriands in 1915, 1917 and 1918 (see Young 2004) - people were so afraid of the invisible sorceresses that were believed to come and attempt to feed on the corpse that "the immediate neighbourhood of the grave [was] absolutely deserted when night approache[d]" (Malinowski 1974: 153 [=1916]). ${ }^{7}$ Contrary to the time of Malinowski's sojourn in the Trobriand Islands the body is no longer exhumed and inspected for signs of sorcery, the children of the deceased are no longer expected to clean the bones - actually this was forbidden by the Australian patrol officers, the 'Kiaps', in the Australian colonial times - the buried person is not exhumed a second time either hence and not reburied (see Malinowski 1929: 132ff).

When the death watch is finished, people from the village of the deceased as well as people from neighbouring villages recongregate to bewail the deceased person. They enter the house of the deceased and ritually cry for the deceased again by literally weeping barrels. After a few minutes of loud and seemingly uncontrolled crying they leave the house. In the village the public mourners cry and shout their kasolukuva mourning formulae. This second mourning rite as well as the house where this second public bewailing of the dead person happens is called libu (see also Weiner 1976: 64). After this libu which may last for a few hours, the villagers prepare for the first of many mortuary distribution rituals that "continue at intervals for months or even years" (Malinowski 1929:31). During these mortuary ceremonies food, grass-skirts (doba), Amphlett pots (see Lauer 1970, 1971; Senft 1985:480) and other valuables are distributed in honour of the deceased and as a payment for the mourning activities of the villagers from other clans who are related to the dead person patrilaterally or through marriage, the "toliyouwa". The members of a deceased's clan, the "toliuli" are the ones who "...have the onerous task of giving away their resources, such as yams, pigs, and stone axe-blades

7. Rosalind Moss (1925:84) reports - somewhat contrary to Malinowski (1974: 153 [=1916]) and to my experience that "in the Trobriands ... internment finally takes place at sunset". She confirms my observation that "a vigil was (formerly) kept by the grave" to guard the body of the deceased against the munukwausi. (Moss 1925:105). 
(beku), the traditional male valuables, as well as skirts and bundles of banana leaves, the valuables of women" (Weiner 1988:37; see also James 2002). Trompf rightly characterizes these mortuary ceremonies as an "immense social and economic upheaval ... which is one of the most salient features in the culture" of the Trobriand Islanders (Trompf 1991:41). This first distribution ceremony is called "sigiliyawali" (see Senft 1985:483ff).

Here I end my description of what happens on the Trobriand Islands when a person dies. I now want to briefly explain these cultural phenomena from a more general perspective (see Senft 1985:488ff).

\subsection{The Trobriand Islanders' belief in a "baloma" spirit}

It is a trivial, though pertinent fact that every case of death implies a loss for the persons left behind. The smaller the group is which is affected by it the more serious is this loss, because it disturbs and even endangers the relationships between members of the group within its "social network". It is obvious that such a situation easily causes conflicts. The loss of a person implies frustration which results not only in grief but also in rage, fury, anger and aggression. ${ }^{8}$ These feelings need to be channelled (see Lorenz 1973:261) to prevent even more harm. This is probably one of the reasons why cultures developed mourning rituals. Scheff (1977:488) defines ritual as the "distant re-enactment of situations of emotional distress" - if we accept this relative simple definition, ${ }^{9}$ then mourning rituals and lamenting the dead are ritualized actions par excellence and certainly belong to "the most characteristic acts of ceremonial life" (Malinowski 1926b:33).

Human ethologists and ethnographers have shown that mourning is a universal feature of human behaviour (see e.g. Damon \& Wagner 1989; Counts \& Counts 1985; Metcalf \& Huntington 1991; Venbrux 1991). Mourning evokes comfort and support and inhibits aggression (see e.g. van Gennep 1909: 146-165; Eibl-Eibesfeldt 1981). Moreover, it is evident that mourning rituals are always rooted within the sphere of religion - in its broadest sense (see Malinowski 1925 [= 1974:17-92]). Thus, public mourning with its various forms of verbal and non-verbal

8. I want to note here that Kilivila has a rich inventory of terms (nouns, verbs, adjectives and idiomatic phrases and expressions) to precisely refer to, and to differentiate, a broad range of emotions and inner feelings (see Senft 2011).

9. For more sophisticated attempts to define the concept of "ritual communication" see the introduction and the contributions in Senft and Basso (2009). 
behaviour and its different levels of complexity does not only express grief but also channels emotions, especially aggression, and thus contributes decisively to social bonding within the group affected by the loss of one of its members. The mourners are not left alone - "the group steps in" (see Malinowski 1925 [=1974:62) - mourning becomes a "shared experience" (Feld 1982:34) and the danger of destroying the group's social network is warded off. Thus, mourning not only becomes a social event but a social duty (see Malinowski 1926b 33f, see also $44,51,66 f$.). In addition to the social components of mourning, religion, belief and myth are decisive for helping the mourners and the bereaved to finally overcome their loss, their sorrow and their fear of death. As Malinowski (1932: 82) points out,

... the idea of death is fraught with horror, with a desire to remove its threat, with the vague hope that it may be, not explained, but rather explained away, made unreal, and actually denied. Myth, warranting the belief in immortality, in eternal youth, in a life beyond the grave, is not an intellectual reaction upon a puzzle, but an explicit act of faith born from the innermost instinctive and emotional reaction to the most formidable and haunting idea.

The Trobriand islanders explain the idea of death away with their belief in an immortal spirit, the baloma. This kind of

... religious revelation ... affirms life after death, the immortality of the spirit, the possibilities of communion between living and dead. This revelation gives sense to life, and solves the contradictions and conflicts connected with the transience of human existence on earth...

(Malinowski 1963b:314)

From this religious point of view mortuary rituals can then be understood as "the enactment of the truth of immortality" (Malinowski 1963b: 314).

On the Trobriands death is understood as "the starting point of two series of events" (Malinowski 1974: 149 [=1916]). After the community members have bewailed the deceased in the first mourning and distribution ceremonies immediately after his or her death, they continue to act out these mourning rituals in what Malinowski (1974: 149 [=1916]) called "an endless series of feasts" which should match with the social status of the deceased person. The second event relates to the immortal spirit of the deceased, the baloma - who is "like a reflection (saribu) in water" (Malinowski 1974:167 [=1916]). This baloma leaves the body of the dead human being and after a while - but no later than the end of the sigiliyawali distribution ceremony - has to go to another world.

Malinowski (1974:149f. [=1916]) points out that the "social activities and ceremonies have no connection with the spirit ... It is possible therefore, to discuss the native beliefs in afterlife without touching the subject of mourning and mortuary ceremonies. The latter are extremely complex". And this is what I will 
do now; that is, I will discuss the Trobriand Islanders' belief in afterlife without a detailed discussion of their complex mourning and mortuary ceremonies ${ }^{10}$

Malinowski (1963a: 262) emphasizes that the desire for immortality is one of the main sources of religious inspiration because it is religion which promises immortality for human beings. As briefly mentioned above, the Trobriand Islanders, like other people in Melanesia in general (see e.g. Ketobwau 1994: i) and in the Massim area in particular (see Section 2.6 below, especially Bromilow 1929: 88ff; Chowning 1983:421, 427; Moss 1925:13, 34f, 44, 53; Trompf n.d.: 151), believe in an immortal spirit, the baloma who lives in a land of the dead which is an underworld kind of "paradise" located on (or rather under) Tuma Island. The milamala songs - the wosi milamala that are sung after the death of a person and especially during the death watch - are verbal manifestations of the Trobrianders' belief in the baloma. ${ }^{11}$ As we will see in chapter three, most of these songs very poetically and quite erotically describe the 'life' of the spirits of the dead in their Tuma Island underworld. The songs that describe the carefree 'life' of the spirits of the dead in their Tuma "paradise" should console the bereaved, reminding them of the fact that dying is just a "rite de passage" (van Gennep 1909), a transition from one form of existence to another: "The new life ... begins with death" (Malinowski 1929:145). Moreover, the songs may also ease the baloma's grief of parting - remember that the baloma - invisible to the mourners - remains in the village for a day or two after casting off the mortal frame. This short period transforms the baloma's rite of passage into a gradual process of taking leave of the community of the living people. It must be noted here that the Trobrianders believe that another spirit called 'kosi' stays together with the baloma at her or his village until the dead body is buried. The kosi monitors the first mourning ceremonies; if the deceased is bewailed appropriately, this kosi spirit dies; however, if the kosi finds some fault with the

10. I would like to point out that these complex ceremonies - see Weiner (1976) and the contributions in Damon and Wagner (1989); see also Metcalf (1982) - are an important part of Trobriand eschatology as sophisticated means for the relatives of a deceased person to overcome their grief and for the village communities affected by the loss of a person to display their solidarity with their fellow villagers. But this section and the whole book focuses on the Trobrianders' beliefs in the baloma and the afterlife of the spirits of the dead in their Tuma underworld - so I will not write in more detail about these ceremonies here.

11. I want to point out here that the special status of these songs escaped Malinowski's (1929: 132) attention; he just notes “...other[s] sing songs". However, he refers to the fact that "many songs are composed by the spirits" (1929:367), he even gives a brief example of a wosi milamala - the song Usiyawenu (1929:367f.) and he spoke of the "Tuma language" (1967:154); see also Section 2.3 below. 
mourning ceremonies, the spirit will not die and punish the responsible people by playing nasty tricks on them or by even frightening them to death. This concept of the kosi spirit varies not only from Moss (1925:64) who states that "[i]n the Trobriand Islands there is a mischievous kosi (as distinct from the baloma which goes to Tuma), the spirit of the dead man which haunts the village, but vanishes after a few days..., but also from Malinowski (1926b: 90) who claims that only sorcerers (bwagau) have a "kousi which spooks round the grave and plays various tricks ... ". Malinowski further characterized this spirit - incorrectly, according to my consultants - as "a frivolous, yet harmless hobgoblin, playing small tricks ... [who] ... will never do any actual harm” (Malinowski 1974: 151 [=1916]). In 1982 and 1983 some of my consultants claimed that they had frightening encounters with a kosi in the bush (see also Senft 2010a: 203f.). ${ }^{12}$ But back to the baloma.

Seligman (1910:734) found that according to the Massim “... pigs, dogs and all birds have a soul or spirit, which like that of man is called barom, fish too have barom, but not trees.... shadows of living men ... have a subtle essence also called barom which goes to Tuma”.

After the mourning and no later than after the sigiliyawali distribution ceremony the spirit of a dead human being has to leave his or her village to go to Tuma and enter the underworld land of the spirits there. However, before we accompany a baloma on his way to Tuma - and it will be a baloma of a deceased man, because I received all the relevant information on what happens then by male consultants in Tauwema - we have to briefly discuss why the Trobriand Islanders as well as other Massim people believe in an underworld of spirits.

12. Actually, it is not "exotic" at all that the Trobrianders believe in two spirits. Christoph Martin Wieland (1795:74f.) points out that Plato speaks of three souls:

Plato gibt in seinem Timäus dem Menschen drey Seelen, wovon die erste göttlicher und unsterblicher Natur ist und ihren Sitz im Haupte hat, von den beiden anderen sterblichen aber die eine die Brusthöhle, und die andere (deren Begierden bloß auf Befriedigung der körperlichen Berdürfnisse gehen) die Gegend zwischen Zwerchfell und Nabel zu ihrer Wohnung angewiesen bekommen hat, wo sie (sagt der hochweise Timäus) gleich einem Thiere, das nichts zu tun hat als zu fressen, an die Krippe angebunden, so weit als möglich von dem denkenden und regierenden Prinzip entfernt worden ist, um dasselbe desto weniger durch ihr Geräusch und Geschrey nach Futter in der Ruhe zu stören, deren es, zu der ihm obliegenden Besorgung dessen was Allen zuträglich ist, vonnöthen hat. 
In her comprehensive overview of "The life after death in Oceania and the Malay Archipelago" Moss (1925:13) summarizes the Massim concept of an underworld as follows:

In the Massim District of South-east New Guinea we also find the belief in an island afterworld. The true home of the dead of the Trobriands and Marshall Bennets, however, is underground; and as each of these island spirit-lands is situated in a definite locality well known to the natives themselves, and as this part of North Massim has undergone at least two migrations from Melanesia, it is probable that the island-idea is entirely due to migration.

She points out that the Massim District has been largely Melanesianized (Moss 1925: 44) and develops on this insight as follows (Moss 1925:53):

The special features of the Massim underworld, especially the origin myth and the idea of a happy spirit-land, are probably due to the Papuan element among these peoples, which has been superseded by Melanesian immigration.

Moss also refers to Haddon (1920:251 \& 256) who supports this fascinating hypothesis. ${ }^{13}$ However, Seligman who visited the Trobriands in 1904 (1910:660) was probably the first scholar who reported about "Tuma ... the reputed other-world to which the spirits of the dead from the Trobriands, the Marshall Bennets, Murua, Tokunu and probably Nada all go". He also pointed out that "[ $t]$ he world was originally colonized from Tuma - the other world". Malinowski (1932:83f.) elaborates on this mythical "fact" and briefly summarizes the myth which explains why the Trobriand Islanders' society is stratified in its rather rigorous clan hierarchy as follows:

The world ... was originally peopled from the underground. Humanity had there led an existence similar in all respects to the present life on earth. Underground men were organized in villages, clans, districts; they had distinctions of rank, they knew privileges and had claims, they owned property, and were versed in magic lore. Endowed with all this, they emerged, establishing by this very act certain rights in land and citizenship, in economic prerogative and magical pursuit. They brought with them all their culture to continue it upon this earth. There are a number of special spots ... called "holes" or "houses". From such "holes" the first

13. Note that Malinowski (1932:95) points out that Laba'i where the first humans are said to have emerged "lies on the north-western beach, the only place open to sailors who would have come from the direction of the prevailing monsoon winds...”. 
couples (a sister as the head of the family and her brother as her guardian) came and took possession of the lands...

... The problem of rank ... was settled by the emergence from one special hole, called Obukula, near the village of Laba'i ... From this hole ... there emerged representatives of the four main clans ... First there came the Kaylavasi (iguana), the animal of the Lukulabuta clan, which scratched its way through the earth as iguanas do, then climbed a tree, and remained there as a mere onlooker, following subsequent events. Soon there came out the Dog, totem of the Lukuba clan, who originally had the highest rank. As third came the Pig, representative of the Malasi clan, which now holds the highest rank. Last came the Lukwasisiga totem, represented in some versions by the Crocodile, in others by the Snake, in others by the Opossum, and sometimes completely ignored. The Dog and Pig ran round, and the Dog, seeing the fruit of the noku plant, nosed it, and then ate it. Said the Pig: "Thou eatest noku, thou eatest dirt; thou art a low-bred, a commoner; the chief, the guya'u shall be I". And ever since the highest sub-clan of the Malasi clan, the Tabalu, have been the real chiefs. ${ }^{14}$

In his further discussion of Trobriand myths that are connected with death and with the recurrent cycle of life, Malinowski (1932:98) points out that the emergence of humans on earth and entering the underworld land of the spirits of the death closes a circle - having once emerged from a hole humans will return to the underworld home of the spirits of the dead also through a hole (although through a different one):

In certain versions of origin myths the existence of humanity underground is compared to the existence of human spirits after death in the present-day spiritworld. Thus, a mythological rapprochement is made between the primeval past and the immediate destiny of each man ... The parallel between primeval and spiritual existence can be drawn even further. The ghosts of the deceased move

14. Compare also Ketobwau (1994:2 \& 15):

"... Trobrianders emerged out of the womb of the earth. Tuma was believed to be the core of mother earth ... Not all clans in the Trobriands emerged from "Obukula". Many came from the sea, called 'Ugwawaga' [visitors, GS]. One such group was the Kabata subclan of the Lukulabuta clan who emerged from a hole near Mount Kabatra in Woodlark. They travelled on seven big canoes to the Trobriands via Gawa...” 
after death to the island of Tuma. There they enter the earth through a special hole - a sort of reversed proceeding to the original emergence. ${ }^{15}$

(Malinowski 1932:98)

It is now time to come back to the baloma of the dead Trobriand Islander who must prepare himself to leave his former village and his beloved ones and who has to go to Tuma. ${ }^{16}$

15. Eric Venbrux (personal communiction) rightly points out that this idea reminds us of initiation rites (see e.g. van Gennep 1909 and Metcalf \& Huntington 1991).

16. Simeon Namunu (1984:93; see also Ketobwau (1994:20)) describes the general importance of spirits for Melanesian communities as follows:

Melanesian communities are spirit-centered and all explanations as to how and why things happen are concerned with the super-natural activities of the spirits. Peoples' social, emotional, educational, political, economic and religious life is based on their feeling towards and belief in the spirits. The spirits in such traditions form and shape the direction and the pattern of behaviour to such an extent that everything one does is guided by spiritual order. 


\section{The spirits of the dead and their underworld life on Tuma Island}

\section{Trobriand eschatology}

Eventually, the baloma has to leave his or her village and his or her beloved ones and go to Tuma. In this chapter I give an overview of the Trobriand Islanders' eschatology - that is their ideas about the end of things and their belief in some kind of existence after death. I first describe the journey of a male baloma ${ }^{17}$ from his village to Tuma and his encounter with Topileta, the "headman of the villages of the dead" (Malinowski 1974: 156 [=1916]). Then I report what the Trobrianders believe to happen when the new baloma is greeted by the other spirits of the dead. After that I characterize the life and the qualities of the baloma and present the myths that explain why they no longer live together with their relatives in the villages; why they are invisible now and why they only visit their old villages once a year during the milamala festival. Then I report on what happens, according to the Trobriand Islanders' belief, when a baloma wants to be reborn. The chapter ends with a comparison of these eschatological beliefs with eschatological concepts elsewhere in the Massim area and in the Pacific.

\subsection{A baloma on his way to Tuma and his encounter with Topileta}

According to my consultants, the baloma finally leaves his village, goes to the beach and swims to Tuma Island - following a route that is specific for the island where he had lived. Malinowski (1974: 155 [=1916]) mentions a canoe "being of a 'spiritual' and 'immaterial quality ... no ordinary man would see" in which a baloma sails to Tuma. Tuma is an island in the north-west of the islands Kaile'una and

17. As mentioned, I can only report on the fate of a male baloma, because I received all the relevant information on what happens with and to him only by male consultants on the Trobriand Islands. It is very difficult for a man to talk about these topics with women - not only on the Trobriand Islands, but in Melanesia as a whole. 
Kiriwina which was uninhabited for a long time after a severe malaria epidemic shortly before World War II. At the end of the 1990s people from Tauwema moved to Tuma and built a new village there. In 1983 Vaka'ila, one of the oldest men in Tauwema who had lived on Tuma, told me that people in the villages there found the atmosphere quite spooky (see also Connelly 2007:136). The routes on which the baloma swim or sail to Tuma come together at a relatively high coral reef at the southern tip of Tuma - they can be seen as breaks in the coral cliff. The routes end at a hole (with a diameter of approximately $25 \mathrm{~cm}$ ), and this hole is the entrance to the Tuma underworld. The entrance is guarded by Topileta. According to my late consultant Tokunupei, Topileta is one of the four children of the primordial father Tudava and his wife Moyetukwa; ${ }^{18}$ and he is the headman of the underground villages of the baloma on Tuma (see Senft 2008a: 142). Malinowski (1974:121 [=1926a]) refers to him as a 'culture hero' and compares him with other mythical figures like Cerberus (Malinowski 1974:151 [=1916]), and St. Peter (Malinowski 1974: 156 [=1916]). Seligman who visited the Trobriands in 1904, reports that Topileta is a member of the Malasi clan (Seligman 1910:733); according to Malinowski (1929:362), who obtained this information more than ten years later, he belongs to the Lukuba clan. Seligman (1910:733) reports that he is said to live together with his children and his wife who looks after his garden; ${ }^{19}$ according to Malinowski (1929:362) he lives with a daughter or several daughters in the vicinity of the Modawosi stone (Malinowski 1974: 156 [=1916]; see also Ingham 1996: 565). He is said to have large "ears which flap continually, [he] has an insatiable sexual appetite, is covered in tattoos, dwells in and is the master of Tuma, but otherwise is exactly like mortal man, though much larger" (Glass 1986: 56; see also Howes 2003: 114f.). Moss (1925: 114) reports that he

$\ldots$ is said to be very like an ordinary Trobriand Islander as regards his life, but has certain magical powers such as causing earthquakes, and when old makes 'medicine' which restores youth to himself and his family; he is bigger than a mortal man and covered with tatu, but otherwise resembles man. Whether he is supposed to exert any authority in the other world seems uncertain, though it is clear that in the first instance the dead were regarded as going to a country which belonged to him, and that he therefore inspects all new-comers...

18. The other children of Tudava and Moyetukwa are Imdeduya, Yolina, and Nabwakesa (see Senft 2008a: 142).

19. Malinowski (1974:157 [=1916]) refers to Topileta's wife with the name Bomjamuia; according to Seligman (1910:733) she is called Tenupanupaia. It may well be that Topileta had more than one wife, though. 
Malinowski (1974: 155f. [=1916]) describes the arrival of a baloma on the southern point of Tuma as follows:

On the beach of Tuma there is a stone called Modawosi, on which the spirit sits down and wails... Then the baloma goes to a well, called Gilala, and washes his eyes which renders him invisible. From here the spirit proceeds to Dukupuala, a spot in the raiboag where there are two stones called Dikumaio'i. The balom knocks these two stones in turn. The first responds with a loud sound (kakupuana), but when the second is hit the earth trembles (ioiu).

This is heard by Topileta and he comes to inspect the newcomer (see Namunu 1984:43ff). In general Topileta admits all baloma into the underworld; however, he also has the right and the power to refuse admission. If he does so, his decision is not based on moral considerations (see Malinowski 1974:156). Baloma usually "share equally in the life of the other world, whether they have been good or bad, strong or weak in this world" (Seligman 1974:733). If Topileta denies a baloma access to the Tuma underworld, he does so because he is not satisfied with the payment that must be made by every newcomer. According to my consultants Topileta is satisfied these days if he receives a betelnut - remember that a betelnut is inserted into the mouth of deceased persons before they are wrapped into mats in which they are buried. However, in Malinowski's days Topileta expected valuables - the vegua - with which the corpse was decorated: He reports that " $[t]$ he spirit is supposed to carry these away with him to Tuma - in their "spiritual" aspect, of course.... the spirit carries these valuables in a small basket and makes an appropriate present to Topileta..." (Malinowski 1974: 156 [=1916]; 1929:362). If a baloma is not admitted to the underworld, the spirit will either be banished into the sea and become "a vaiaba, a mythical fish possessing the head and tail of a shark and the body of a stingaree" (Malinowski 1974:157f. [=1916]) or become an animal or insect (see Moss 1925:148; 150). Topileta will ask the baloma why they have died, and - according to one of Seligman's consultants - "all reply that they do not know, but that they have come to him" (Seligman 1910:734). This is contradicted by Malinowski (1974: 156 [=1916]) who reports that

Topileta asks the newcomer the cause of his death. There are three classes - death as the result of evil magic, death by poison, and death in warfare. There are also three roads leading to Tuma, and Topileta indicates the proper road according to the form of death suffered. ${ }^{20}$

20. Compare Simeon Namunu (1984:40) who rightly points out that “... death to Trobrianders was caused by war, poison and sorcery ... death was not seen as a natural event...”. And this is still the case (see also Malinowski 1932:100ff). 
Namunu (1984:45) also refers to three roads that lead to three villages in the underworld; the first road is called "Tuma proper", the second one is called "Wabwaima" which can be glossed as "to the yams storage houses" (va bwema) and the third one is named after the high platforms of chiefs, "Bomiamuia". My consultants did not say anything about such a conversation and these roads. They only told me that Topileta asks the baloma for his gift, then he takes him to a nearby coral stone that looks like a stalagmite. This stone is called 'gilela va sopi. There is a tiny mould on top of this stone which is always filled with a little bit of water. Topileta wets his finger with this water and wipes his wet finger over the eyes of the 'baloma' who then can see the Tuma underworld and may enter it. However, I was also told that if the guardian deals with a very beautiful female 'baloma', he may also ask her for some sexual favours. This agrees with Malinowski's (1929:363) report that "if the spirit is a female, [Topileta] copulates with her"; ${ }^{21}$ what my male consultants did not tell me is that Topileta is said to usually hand a male spirit "over to his daughter for the same purpose" (Malinowski 1929:363). After this encounter with Topileta (and his daughter) a baloma can enter the underworld through the entrance hole on the high cliff at the southern point of Tuma Island. ${ }^{22}$

\subsection{How the newcomer is welcomed by the other baloma in the Tuma underworld}

Malinowski reports two different versions of what happens when a baloma has entered the underworld. The first version simply states that the baloma is still full of grief, sits down at the beach and cries. The earthquake announced the other baloma that a new spirit will soon enter their world. When they hear the crying of the new baloma, the spirits of his kinsmen and friends who died and went to Tuma before him, come towards him, join in his lamentation and then bring him to their village where all the other baloma congregate round him and welcome him (see Malinowski 1974: 155 [=1916]).

The other version which Malinowski reports in his monograph "The Sexual Life of Savages in North-Western Melanesia” is more elaborate, sexually quite

21. Note, however, that Malinowski (1974: 157 [=1916]) also reports that "[t]he female spirits are shown the way by Topileta's wife Bomjamuia".

22. Baldwin (1950:282) rightly points out that despite Topileta's importance for the Trobriand Islanders there is no "myth or legend connected with him"; and Malinowski (1974: 157 [=1916]) emphasizes that "beyond his initial meeting with all spirits, he does not in any way interfere with their doings" (see also Seligman: 1910:733). 
explicit and agrees with what my consultants told me. Because of the earthquake the spirits of the dead know that a new baloma will soon enter their world. They also know that this newcomer arrives full of sorrow because he still remembers his beloved ones, especially his wife or, if he died as a bachelor, his girl-friend(s). Therefore they "conspire to break his attachment by aggressively seducing him" (Howes 2003: 189). They first boil the scented leaves of a mint plant called sulumwoya in coconut oil. Then they recite a love magical spell on it and thus produce the bubwayata potion. The magic is called after the mint plant sulumwoya; it is by far the most important love magic and is associated with a specific myth which Malinowski (1927:126-128; see also 1932:113f.) reports in great detail. I will briefly summarize this beautiful myth here:

In the village Kumilabwaga lived a woman of the Malasi clan with her son and her daughter. One day her son made love magic to gain the love of a beautiful girl. He put pungent kwayawaga leaves and sweet-scented sulumwoya mint leaves into clarified coconut oil, boiled the mixture and recited the sulumwoya love magic on it. He then poured it into a container and placed it in the thatch. After that he went to the sea to have a bath. In the meantime his sister wanted to fetch fresh water from a nearby water well. She passed under the spot where her brother had stored the magical oil and some of this liquid dropped on her hair. She brushed over it and sniffed at it. Mad with passion she looked for her brother, found him at the beach, bathing in the nude, chased him and seduced him there. Ashamed and remorseful, being aware that they just had committed incest and thus violated the strict brother-sister taboo which not only forbids incest but also prescribes that siblings must not know anything about each other's erotic engagements or love affairs (see Malinowski 1929:36, 84f., 433-451; Senft 1995:222f.), but still full of love and passion, they went to the grotto Bokaraywata, forsook food and drink and died together, clasped in one another's arms. Through their linked skeletons grew the mint plant sulumwoya, "the most powerful ingredient in the substances compounded together and used in love magic" (Malinowski 1932:114; see also Baldwin 1945: 229).

But let us return to the baloma in Tuma again. When the love magic is ready, it is put on an aromatic herb called bubwayayta. The baloma then put this vana - this bundle of herbs with the love magic - into the kwasi armlets ${ }^{23}$ of the most beautiful, most passionate and loveliest baloma woman and send this "hostess spirit" (Howes 2003:189) to the crying man. She runs to him, and

23. Kwasi are armlets made of natural fibres worn by men and women on their upper arms; they emphasize the men's muscles and frame the women's breasts - thus increasing the physical beauty of the persons. 
waves the scented herbs under his nose. Malinowski compares the function of the bubwayayta magic with the

first sip of the water of Lethe ... [t]his scent makes [the newly arrived baloma] forget all that he has left on earth ... His only wish now is to remain in Tuma and to embrace the beautiful though unsubstantial forms of the spirit woman... Spirit women ... have ire and passion to a degree unknown on earth. They crowd round the man, they caress him, they pull him by force, they use violence on him ... The man submits to these advances and copulates with the hostess-spirit in the open"

(Malinowski 1929:363; see also Kurtz 1991:79)

Kurtz (1993: 100f.) makes the interesting observation that despite the powerful love magic which induces forgetfulness and creates passionate sexual arousal, "the female spirits must still exercise force on the male ... [and] ... use aggressive seduction in order to break the male spirit's attachment to his earthly wife". ${ }^{2}$

Thus, the baloma's feelings of love and affection for the partner(s) he left behind are played off by those baloma already living in Tuma against rather blunt sexuality, which is only later combined with more sophisticated forms of eroticism - that are reported in the wosi milamala. As Bettina Beer (p.c.) rightly points out, this is clear evidence for the fact that the Trobriand Islanders assign "sexuality" on the one hand and "love" on the other to two different emotional/sensual domains. This made Kirsty Gillespie (personal communication) suggest that the title of this book could also have been "The Trobriand Islanders' Underworld of Lust".

But back to the baloma in Tuma. The newcomer's aggressive seduction by the female spirits happens in open view of the other baloma. The situation soon escalates. The sight of the copulating couple stimulates the other baloma to do the same and this results in a wild orgy on the beach. Malinowski (1929:364) points out that according to his consultants "[s] uch promiscuous sexual orgies, in which male and female mix indiscriminately, congregate, change partners and reunite again, are frequent among the spirits".

Kurtz (1991:81) rightly points out that "Trobriand sex generally transpires in strict privacy" ${ }^{25}$ however, on the basis of Malinowski's reports he observes that in

24. "Passionate sexuality for the Trobrianders involves lip, nose, and eyelash biting, scratching, and hair pulling" (Ingham 1996:571).

25. Note, however, that Malinowski (1929:217ff.; 382) reports that in former times - long before he first set foot on the Trobriands - villages in the extreme south of Vakuta practiced a kayasa - an erotic competitive festival called kamali - in which "[s] exual acts would be carried out in public on the central place; married people would participate in the orgy, man and wife behaving without restraint, even though within hail of each other" (Malinowski 1929:219). He also mentions a tug-of-war kayasa between men and women which also ended in a public orgy. 
the Tuma underworld a baloma will experience "two phases of sexual life ... In the first, the new baloma, preoccupied with an earthly love, is alternately seduced and forced into sex. Later, the experienced baloma freely engages in orgiastic sex and ... initiates newcomers" (Kurtz 1991: 81). It is only the baloma who are permanently released from the taboo of publicity in sexual matters (see Malinowski 1929:382). This first encounter with his fellow spirits of the dead is exemplary for the future life of the baloma in the Tuma underworld.

\subsection{The life of the baloma in their Tuma underworld and their qualities}

Malinowski and others who have written about Trobriand Islanders' conception of the underworld of their spirits of the dead emphasize the primacy of sexuality in Tuma.

Tuma remains a paradise, and above all an erotic paradise. When a native talks about it, when he grows eloquent ... all other aspects soon fade into the background and sex comes to the fore... In their anticipations, Tuma is thronged with beautiful women, all ready to work hard by day and dance by night: The spirits enjoy a perpetual scented bacchanal and dancing and chanting on spacious village-places or on beaches of soft sand amid a profusion of betel and of green coco-nut drinks, of aromatic leaves and magically potent decorations of wealth and insignia of honor.

(Malinowski 1929:361f.)

"While the women's view may have been rather different (Stocking 1977), according to Trobriand men the afterlife was an endless sexual orgy among the Tuma beauties, who greatly outnumbered men" (Glass 1986:56). "On Tuma everything revolves around sex" (Howes 2003: 189); it "is an 'erotic paradise, filled with singing, dancing, and sexual orgies" (Spiro 1992:360), "the inner world of the dead ... is amorphous and dominated by egocentric desire and ... magic that influences the desires of other spirits" (Ingham 1996:565).

The baloma's sexual activities are usually preceded by their wooing for a partner. Baldwin (1945:235) notes that “...begging [for a betelnut, G.S.] is the first definite advance of a woman towards a man" - in the Tuma underworld as well as everywhere on the Trobriand Islands, and Malinowski (1974:260 Footnote 20 [=1916]) points out that

... wooing in Tuma ... corresponds to the manner in which people mate on certain occasions called katuyausi. The katayausi are expeditions of amorous adventure, in which the unmarried girls of a village go en bloc to another village and there sleep with the youths of that village. Any single male who fancies one of the girl guests gives her (through an intermediary) some small present (a comb, 
some shell discs or turtle shell rings) ... If accepted, the two belong to each other for the night.

Baloma also marry - some of the male baloma sometimes marry more than one wife, not least because there are more women than men in the Tuma underworld and because these beautiful wives do all the work in the men's rich gardens (see Moss 1925:138; Malinowski 1929:361); thus, male baloma are really "free from toil and hardship of the 'upper world"' (Ketobwau 1994: i).

However, the lives of married couples in Tuma differ from the lives of married couples in the upper world in many respects (see Malinowski 1929; Sprenger 1997:101ff). Before marriage bachelors have many affairs with young women, and the more they have the more status they achieve. The erotic marks that women afflict to their partners during sexual intercourse - like biting off the eyelashes and scars inflicted on the male body by biting and scratching are proudly presented by young males as public signs of their sexual attraction. However, he has to pay his partner for these marks in the form of small gifts like, for example, shell ornaments or necklaces. These sexual affairs precede marriage and test whether partners would be able to keep up the relationship and finally transform it into marriage. These affairs are publicly discussed - restricted only by the "brother-sister taboo" that prescribes that siblings must not know about each other's erotic engagements or love affairs (see Malinowski 1929:36, 84f., 433-451). Once a couple marries, marital eroticism and sexuality is no longer talked about (although parents make no attempts whatsoever to conceal their sexual intercourse from their children, who, however, are expected to not talk about these matters to others). Moreover, married men do not present erotic marks any more and the married couples avoid showing affection for each other in public (see also Sprenger 1997:122). Marriage in the upper world constitutes first and foremost exchange relations between two matrilineal clans. All this does not hold for marriages in Tuma - as the wosi milamala reveal. These marriages seem to be closer relationships between partners in which men can still behave like bachelors being ready for "ulatile" expeditions to other villages to have sexual affairs with women and in which women can make "katuyausi" trips to do the same with men in other villages (Malinowski 1929:222ff; 228ff). This is absolutely impossible for a married couple in the upper world - where the official claim for the ideal form of marriage is monogamy.

Nevertheless, despite this primacy of sex and sexuality in the lives of the spirits of the dead the baloma also can lead what could be called 'an ordinary life' in between their marital and extra-marital sexual activities. After their first marriage they settle down in their new villages (see Moss 1925: 138). Malinowski (1974: 159 [=1916]) mentions three villages in the Tuma underworld - "Tuma” proper, 
"Wabuaima" and "Walisiga". ${ }^{26}$ In their villages the baloma lead a "pleasant existence, analogous to the terrestrial life - only much happier" (Malinowski'1929: 145); all male baloma feel like chiefs, they are beautiful, they have all kinds of body decorations to charm female baloma, and their betelpalms, coconut trees and rich gardens produce betel- and coconuts as well as food of all kind in abundance (see also Malinowski 1929:361). ${ }^{27}$

According to my consultants, the baloma live in their Tuma underworld in eternal youth. Malinowski's consultants gave a somewhat different account of the baloma life cycles. According to Malinowski (1974:168 [=1916]) "[t]he baloma live the life of men; they get older; they eat, sleep, love, both whilst in Tuma and on visits". However, they have the faculty of rejuvenation. When they feel too old and/ or ugly they "go to a spring called sopiwina (literally 'washing water'); it lies on the beach. There they wash their skin with brackish water" - then they become young again (Malinowski 1929:147). A long time ago the Trobriand Islanders living in the 'upper world' had this faculty as well (see Malinowski 1932:98); however, they lost it - according to Malinowski's (1932:99) consultants

... by an apparently trivial, yet important and fateful event. Once upon a time there lived in the village of Bwadela an old woman who dwelt with her daughter and granddaughter; three generations of genuine matrilineal descent. The grandmother and granddaughter went out one day to bathe in the tidal creek. The girl remained on the shore, while the old woman went away some distance out of sight. She took off her skin, which, carried by the tidal current, floated along the creek until it stuck on a bush. Transformed into a young girl she came back to her granddaughter. The latter did not recognize her, she was afraid of her, and bade her be gone. The old woman, mortified and angry, went back to her bathing place, searched for her old skin, put it on again, and returned to her granddaughter. This time she was recognized and thus greeted: 'A young girl came here; I was afraid; I chased her away' Said the grandmother: 'No, you didn't want to recognize me. Well, you will become old - I shall die.' They went home to where the daughter was preparing the meal. The old woman spoke to her daughter: 'I went to bathe; the tide carried my skin away; your daughter did not recognize me; she chased me away. I shall not slough my skin. We shall all become old. We shall die.' After that men lost the power of changing their skin and of remaining youthful.

26. Note that the first names are the same as the road names mentioned by Namunu (1984:45) quoted in 2.1 above; Seligman (1910:733) mentions the Tuma village name "Wilakatutara"; in Chapter 3 we will learn about more Tuma villages and their names.

27. Contrary to many other peoples of Papua New Guinea the Trobriand Islanders do not cut a deceased's betelpalms and coconut trees after his or her death. 
Moreover, Malinowski's consultants also told him that in former times the baloma did not always go to Tuma after they had died but stayed in their villages and lived together with the survivors. However, again a rather trivial incident made them change their mind; in addition, this incident is responsible for the fact that the baloma are also invisible these days. Malinowski (1932:104f.; see also Gardner 1997: ccclxxxiii-ccclxxxv) reports the following:

$[\mathrm{O}]$ ne day an old woman-spirit who was living with her people in the house crouched on the floor under one of the bedstead platforms. Her daughter, who was distributing food to members of the family, spilled some broth out of the coco-nut cup and burnt the spirit, who expostulated and reprimanded her daughter. The latter replied: 'I thought you had gone away; I thought you were only coming back at one time in the year during the milamala.' The spirit's feelings were hurt. She replied: 'I shall go to Tuma and live underneath.' She then took up a coco-nut, cut it in half, kept the half with the three eyes, and gave her daughter the other. 'I am giving the half which is blind, and therefore you will not see me. I am taking the half with the eyes, and I shall see you when I come back with other spirits.' This is the reason why the spirits are invisible, though they themselves can see human beings.

However, a baloma still can return to his or her village from time to time and thus stay in touch with the living world. And baloma in the Tuma underworld can be visited by baloma of his or her surviving friends and relatives (see also Mosko 2010: 171, Footnote 7). In 1983 Isilena - a woman in her late 70s who lived in Tauwema - claimed that her baloma regularly visited Tuma while she was in a trance-like sleep; she reported one day that my house there was already built and that the metal "Zarges" boxes with my belongings were inside - just waiting for my baloma to come and live there. In this way Isilena revived the image of Tuma continually. She was sometimes even asked by other people to deliver messages to the baloma of their deceased kinspeople. This is in agreement with the reports of Seligman's (1910:734) consultants:

... barom [= baloma, G.S.] might leave the body without death ensuing, and this may occur not only in sleep, when the experiences of the barom may be translated into dreams, but may also be brought about intentionally. There are individuals who say that they have visited Tuma and returned to the upper world. ... One Marogus of Kavataria ... his barom visited Tuma ... he saw inhabitants of the other world make gardens, marry and beget children. It was pointed out that Marogus had not eaten or smoked with the shades, since if he had done so he would have been unable to return to the upper world...

... The barom of the dead are seen in dreams when they talk to the living in a curious whistling speech, inviting them to visit Tuma and extolling the abundance and excellence of its crops and the size of its yams. 
Some of the magicians in Tauwema also reported that baloma of their predecessors appear in their dreams to give them advice for and in performing their magic (see also Malinowski 1922:422f.). Other people who claim to have visited Tuma bring songs with them and make their fellow villagers learn and stage them (see e.g. Baldwin 1945:204). These songs are sung in the "biga baloma" - the language of the spirits of the dead - which is also called "biga tommwaya" - the language of the ancestors. This variety is far from being "a curious whistling speech" - as Seligman was told by his consultants, but an archaic variety of Kilivila. I will discuss this language variety in detail in chapter three. For the purposes pursued here I just want to point out that the baloma have a language variety of their own. Malinowski (1929:367) briefly mentions that the baloma compose songs, some of which "reach the earth, brought thither by mediums"; he describes these songs as "... celebrating dancing and personal beauty ... mainly as a setting and a preliminary to sex enjoyment ..." and even documents a few stanzas of the song "Usiyawenu" in his English translation; unfortunately, he does not make any remarks with respect to the language in which this song was sung. In his diary (Malinowski 1967:154), however, he reports on a "vocabulary of the Tuma language" which was given to him by one of his consultants, but his only comment on it is that this variety is "very guttural". Father Baldwin, who was the first to document two song cycles that were composed and sung in the biga baloma refers to this variety as a "secret language that will never divulge" and points out that " $t]$ here certainly is an archaic form about many of the words" (Baldwin 1945:202; see also 1950). ${ }^{28}$ As mentioned above, I will take up this fascinating issue of the biga baloma in the next chapter. The next section of this chapter will explain why the baloma visit their former villages in the upper world regularly during the time of the "milamala" harvest festivals.

\subsection{The baloma visiting their former villages during the harvest festivals}

As mentioned above, the baloma no longer stay in their former villages; however they visit them from time to time. During the milamala harvest festival period,

28. I would like to point out here that in 1996 Giancarlo Scoditti published a selection of what he calls 'Kitawa Oral Poetry' or 'Nowau poetic formulae'. Chapter three of his book presents these 'poetic formulae'. Unfortunately, Scoditti does not differentiate the genres presented there (Scoditti 1996:56). His 'poetic formulae' represent magical formulae, mocking verses and songs in the biga baloma (which will be in the focus of chapter three below). It is surprising that he does not recognize the special varieties of Kilivila in which the songs are sung - the biga baloma - and in which the magical formulae are recited - this variety of Kilivila is called "biga megwa" - the language of magic (see Senft 2010a). 
however, all baloma go back to their former villages, visit them for the time of the milamala and see whether their relatives and other present day villagers are still good gardeners and behave properly according to the traditional Trobriand standards, ethics, and moral principles. The milamala begins in different parts of the Trobriand Islands at different times. As Malinowski (1929:221) points out, "its date is fixed by the appearance of the palolo worm" - an annelid sea worm of the Eunicidae family (palola viridis) - which reaches different islands and parts of the Trobriands at different times. In Kitava, the easternmost island of the Trobriands, the milamala usually starts in June; in the northern part of Kiriwina the harvest festival begins in July, the southern part and the outlying islands celebrate milamala in August, and on Vakuta, the southernmost island of the Trobriands, the festival starts in September/October. This annual feast can be regarded as the Trobriand Islanders' indigenous "new year" (see Malinowski 1935 Vol. I: 54; see also Senft 1996). In Section 2.3 I already quoted the myth which explains why the baloma no longer live together with their relatives in their villages; Malinowski (1932: 105f.) reports yet another myth which has some resemblance with the myth just mentioned; however, this more elaborate myth explains how the milamala was instituted; Malinowski retells this myth as follows:

A woman of Kitava died leaving a pregnant daughter behind her. A son was born, but his mother had not enough milk to feed him. As a man of a neighboring island was dying, she asked him to take a message to her own mother in the land of spirits, to the effect that the departed one should bring food to her grandson. The spirit woman filled her basket with spirit-food and came back wailing as follows: 'Whose food am I carrying? That of my grandson to whom I am going to give it; I am going to give him his food'. She arrived on Bomagema beach in the island of Kitava and put down the food. She spoke to her daughter: 'I bring the food; the man told me I should bring it. But I am so weak; I fear that people may take me for a witch. She then roasted one of the yams and gave it to her grandson. She went into the bush and made a garden for her daughter. When she came back, however, her daughter received a fright for the spirit looked like a sorceress. She ordered her to go away saying: 'Return to Tuma, to the spirit-land; people will say that you are a witch.' The spirit-mother complained: 'Why do you chase me away? I thought I would stay with you and make gardens for my grandchild.' The daughter only replied: 'Go away, return to Tuma!' The old woman then took up a coco-nut, split it in half, gave the blind half to her daughter and kept the half with eyes. She told her that once a year she and other spirits would come back during the milamala and look at the people in the villages, but remain invisible to them. And this is how the annual feast came to be what it is.

(Malinowski 1932: 105f.) 
After getting in the yams harvest and after the dadodiga, the festive filling in of the yams houses with the yam tubers, a high platform is erected for the baloma which the villagers on the Trobriand Islands expect to visit them during the milamala period. From this platform the baloma "can look down upon the doings and amusements of their brethren" (Malinowski 1932:107; see also 1974: 180 [=1916]).

On a specific day when there is a full moon - based on the decision of the village chief, the important garden magicians, and the expert dancing instructor - the villagers formally present yams, taro, sweet potatoes, fish, sugar-cane, and betel-nuts to the baloma just before sunrise in a food distribution called "katukaula". The presents are put on the platform erected for the spirits. In the introduction to this volume I already described that the villagers then dance and sing the milamala songs to honour the visiting baloma. Together with the above mentioned katukaula food distribution for the spirits of the dead, the wosi milamala and the song-accompanying dances mark the official beginning of the 'milamala' period of harvest-festivals.

Although I briefly described what happens on this day in the introduction to this monograph I will describe this ceremony in some more detail again: Most men and some girls dress up carefully in their traditional clothes. The girls wear their so-called 'grass-skirts' (doba) that are made out of fibers of banana leaves. The men wear their traditional loin-cloth (mwebua), made out of the bark of the betel-palm; however, in addition they also wear 'grass-skirts' which were given to them by the female kinsmen of their wives. Although the men in this matrilineal culture are not related whatsoever with these persons, they wear the skirts to honour this group and to show that their marriage has created a bond with these people. Thus, this skirt can also be understood as a sign indicating the good marital relationships between the respective men and their wives - as a woman's ability to contribute bundles and skirts to every exchange during a certain mourning ritual is a public statement of her husband's support and wealth (Weiner 1976:198) - because the "major responsibility of a man to his wife is to provision her with additional wealth in 'doba"' (Weiner 1976: 197).

All the dancers - the 'towosi' - decorate their faces with asymmetrical ornaments in red, white and black colors which are made out of betelnuts, chalk and charcoal respectively. They anoint their bodies with coconut oil and an essence made out of fragrant herbs and afterwards sprinkle their torsi with yellow leaves taken from the blossoms of a certain tree. They all wear white feathers of cockatoos in their carefully combed hair and armlets made of natural fibers on their upper arms which emphasize the men's muscles and frame the girls' breasts - thus increasing the physical beauty of the persons. Some of the dancers also wear necklaces - the so-called "bagi" made out of the red parts of the spondylus shell-, tortoise-shell 
earrings (paya), and boars' tusks ( $\operatorname{dog} a)$. Moreover, some men also wear belts made of small white kauri-shells around their waists, knees and/or foot-ankles (bunadoga, luluboda and kwepitapatila respectively). Most of these adornments do not only mark the wealth of their bearers but also their status within the highly stratified Trobriand society with its clans and subclans. ${ }^{29}$

After some final magical rites, where the dancers' relatives or the dance master of the village whisper magical spells on their body to make them dance more gracefully, the dancers gather at the centre of the village, where in the meantime a group of mostly elderly men, some with drums and some with long sticks, has gathered. As soon as this group starts to sing and drum, the dancers start dancing in circles around them, holding pandanus streamers (bisila) and cassowary feather plumes (vavega) in their hands as additional decorations. The drummers - the 'towosi kesosau' - have three different types of drums: small ones, the 'katunenia', which signal changes in drum rhythms and dance movements, drums of medium length, the 'kupi', and long drums, the 'kesosau'. The 'wosi milamala' are intoned and ended in a very specific way, they are repeated ad libitum and they have a very characteristic melody (see Chapter 3 ). The singing and dancing may last for more than three hours.

The 'milamala' songs are a salute to the 'spirits of the dead' and honour and celebrate them (see Eibl-Eibesfeldt \& Senft 1991; Senft 2003). They are the verbal manifestation of the Trobrianders' belief in the baloma. The songs very poetically and quite erotically describe the 'life' of the spirits of the dead in their Tuma underworld. As pointed out elsewhere (Senft 2009a) the 'wosi milamala' represent a situation-specific, complex, sophisticated, and extraordinary form of ritual communication in the Trobriand Islands. This ritual communication in the Trobriand Islands, as elsewhere, can be relatively simple and everyday-like - John Haviland (2009a) refers to these forms of ritual communication as "little rituals"- or highly complex and situation-specific. These forms can be located on a continuum or cline of structural, (con)textual, and sociocultural complexity. The 'wosi milamala' certainly represent the more complex extreme of this cline. As a form of ritual communication these songs are results of what Ellen Basso and I (2009:1) call "artful, performed semiosis." They are "formulaic and repetitive and therefore anticipated within particular contexts of social interaction," and they usually (but not always) have anticipated consequences. Moreover, they are performed and therefore "subject to evaluation by participants according to standards that are defined in part by language ideologies, contexts of use, and relations of power among participants" (Basso, Senft 2009:1). And, as we will see, the 'wosi milamala' preserve important aspects of Trobriand Islanders' cultural identity in a very specific way.

29. Weiner (1976:237f) provides a full list of body decorations. 
Malinowski (1974:263f, Footnote $40[=1916])$ points out that during the milamala festival and at some other occasions the Trobriand Islanders dance two main types of dances that are accompanied by the 'wosi milamala': The first group of dances consists of

... circular dances, where the orchestra (the drums and the singers) stands in the middle, and the performers go round them in a circle, always in the opposite directions to the hands of a watch. These dances are again subdivided into: (1) bisila (pandanus streamer) dances with slow movement (2) kitatuva (two bunches of leaves), with a quick movement; and (3) kaidebu (wooden painted shield), dances with the same quick movement. In the bisila dances women can take part (very exceptionally), and all the performers wear women's petticoats. The second group of dances are the kasawaga, where only three men dance, always in imitation of animal movements ... These dances are not circular, there are no songs (as a rule) to accompany them...

However, the kasawaga dances are accompanied by drums.

During the days of the milamala festival food is displayed in big quantities to gladden the hearts of the baloma and in some villages valuables are placed on mats on the verandas of the houses of the chief and of other important and wealthy villagers to also please the spirits of the dead (see Malinowski 1932: 107; see also Trompf 1991:15). During the milamala which lasts for about a month or so, the villagers are careful to observe all kinds of taboos to not injure or annoy the invisible visiting spirits, because they are convinced that the baloma control whether the villagers living there now still know how to garden, how to celebrate a good harvest, and how to behave even while celebrating exuberantly. They are convinced that the "spirits manifest their presence by pleasant and unpleasant signs ... [like] ... unpleasant smells ... bad weather, accidents, damage to property" and so on (Malinowski 1932: 107). According to the Trobrianders' belief the baloma "also keep strict watch over the maintenance of custom, and they punish with their displeasure any infraction of the traditional customary rules which ought to be observed during the milamala" (Malinowski 1974:184[=1916]). And "[d]epending on whether or not they are pleased with what they see, the spirits enhance or hinder the next year's production" of yams (Damon 1982:231). Therefore people take care to not spill hot fluids, throw stones or sticks, try to avoid any kind of misbehaviour and use no indecent expressions with regard to the baloma.

Until the mid-1990s, wosi milamala were also sung in Tauwema in the late evenings during the milamala, and sometimes they formed the transition from one day to the next. This period was characterized by conviviality, flirtation, and amorous adventures. All harvest customs still "favour erotic pursuits" (Malinowski 1929:210). It goes without saying that during this festive period, social norms, rules, and regulations were interpreted more liberally and generously than at other 
times. This might have led to jealousies ${ }^{30}$ and rivalries that, in escalation, would have threatened the community. As my consultants told me, the mere fact that wosi milamala were sung prevented such a development. The songs reminded Trobrianders of the presence of the baloma and of social norms that were - at least in part - valid even for the spirits of the dead and their amorous adventures in their Tuma underworld. Thus the guardians of the norms of the past are present, checking whether that past was still present in their former villages. Although the pleasure, the dancing and the sexual license during the milamala pleases the spirits of the dead, the baloma must not be offended by unseemly and indecent behavior, which includes "publicity and lack of decorum in sexual matters" (Malinowski 1929: 382) as well as jealousy among bachelors. Keeping this in mind, Trobrianders must control their behavior, especially their emotions, because no one would dare offend the spirits of the dead. The singing of wosi milamala assures the community that there is a virtually transcendental regulator controlling its members' behavior and thus warding off developments that might prove dangerous for the community (see also Senft 2009a: 94; 2010a: 30f.).

Malinowski (1929:213) mentions that the period of dancing can be prolonged up to three months - especially if the harvest was excellent, if much food is available and if the "festive mood is exuberant". This extension is called usigola which can be glossed as 'together for a song. However, usually on the night after the full moon the spirits are ceremonially driven away from the villages. This ritualized ceremony is called "yoba": Despite the fact that the baloma are offered parting presents (taloi), men and women, but especially adolescents and children take rotten yams, bananas, other rotten fruits and even coconuts and throw them with a lot of laughter and not too polite remarks from the place where the platform for the baloma was erected to the beach, thus chasing away the spirits (see Connelly 2007: 130). They have to leave their villages now and return to their Tuma underworld. The yoba is followed by a period of quieter festivity, without dancing, however with drumming and the singing of the milamala songs. This period of feasts which may last for three months is called "kalibom". Malinowski (1974:177 [=1916]) noted that the kalibom is "also the proper time for amorous advances among the young

30. Kilivila has the following lexical means to express the concept of "jealousy": The nouns "kaiwada" and "pugipogi" can be glossed as "jealousy, envy", the noun "uliweli" refers to "marital jealousy"; in the Kilivila lexicon we also find the verbal expressions "-nanali-" ( to be bad, to worry, to be jealous), "-pogi-" (to fear, to be jealous, to poison), and "-polu-" (to boil, to worry, to be jealous), the adjectives "-nanali" (bad, wrong, jealous" and "-uliveli" (unjust, jealous) and the phrase "nanola ipolu = nano-la $i$-polu" (mind-his/her it-be jealous = It makes him/her jealous, s/he is jealous). 
people". And Glass (1986:58f.) reports that " the ioba ... was associated with a distinct heightening of sexual activity ... Bellamy's... [1908] study surprisingly revealed that the majority of births occurred in May which meant that most Trobriand conceptions took place during the ioba and its aftermath".

\subsection{From baloma to spirit child: The Trobriand myth of conception}

The Trobrianders have a very special myth with respect to the conception of their children. They take it for granted that a baloma sooner or later gets bored of his or her life in their Tuma underworld. According to my consultants Weyei and Tokunupei the baloma then have three possibilities: They either can change into a spirit child, swim back to the villages on the upper world, slip into the vagina of a carelessly bathing woman of their subclan and then get reborn. However, if they are tired of these continuous life cycles, they may either change into a cowry shell (Cypraea mauritiana) or metamorphosize into a star. This section presents and discusses the first alternative of this indigenous belief in reincarnation in some detail.

If a baloma has decided to be reborn, s/he goes to the sea and takes a bath in saltwater. In this "final rejuvenation" (Malinowski 1929:137) the baloma throws off his or her skin and changes into a spirit child. These spirit children are called "waiwaia" - like children in utero - or "pwapwawa" - like children immediately after their birth (see Malinowski 1929: 151; 1974:216 [=1916]). According to my consultants the spirit child which is invisible like the baloma then either swims to the beaches of the Trobriand Islands by itself or floats around Tuma Island on drift logs, leaves, dead seaweed or even sea-scum and wails to catch the attention of another spirit. Malinowski (1929:147ff) reports that after a while these children are taken up by such another baloma, put into a basket and transported to the Trobriands. There the spirit of the mother or father of the woman who will be pregnant inserts the waiwaia into the head of their daughter. The waiwaia must belong to the subclan of its future mother. This woman will suffer a headache, vomits and will have an ache in the belly. The child is transported by the blood that rushes towards the head down to the belly and then settles in the womb. Then the woman is pregnant. She does not have her mensis any more, because the blood is needed to nourish the baby. The most important aspect of this version of the myth is that "children are 'given by a baloma', that 'a baloma is the real cause of childbirth" (Malinowski 1929:148). Another version of how the spirit children are conceived has the child swim or float on its own to the Trobriands, drifting around the shores and waiting for a woman who belongs to its subclan who takes a bath in the sea. If she swims somewhat carelessly, the spirit child will enter her body through her vagina. The woman will feel that something has touched and slightly hurt her and 
assumes that she was bitten by a fish (see Malinowski 1974:218 [=1916]). Another way to become pregnant is to have a maternal kinsman (i.e. the brother or the mother's brother) of a woman who wants to get pregnant fill a wooden bailer with sea-water and leave it overnight in the hut of this woman - hoping that the bailer might have caught a spirit child that belongs to the subclan of the mother to-be. This child will take its chance to slip into the sleeping woman through her vagina (see Malinowski 1929: 149f.). Malinowski (1929:152f.; see also p. 145) summarizes the gist of these myths in which a man has nothing to do with procreation as follows:

$\ldots$ in all principal points, the various versions and descriptions agree, overlap and fortify one another; and we are left with a composite picture which, though blurred in some of its details, presents a strong outline when viewed from a distance. Thus all spirits rejuvenate; all children are incarnated spirits; the identity of sub-clan is preserved throughout the cycle, the real cause of childbirth is the spirit initiative from Tuma...

... [A]lthough the Trobrianders firmly believe that each spirit becomes a preborn infant, and that this again becomes reincarnated into a human being, yet no consciousness of personal identity is preserved through the process. That is, no one knows whose incarnation the infant is - who he was in his previous existence. There is no remembrance of past life in Tuma or on earth... The only recognized rule which guides these metamorphoses is that the continuity of clan and sub-clan is preserved throughout. ... There is no room for any sort of physical paternity.

Malinowski's account of this concept of conception on the Trobriands and his strong claims that the Trobrianders take these myths seriously - thus being completely ignorant of the role of the 'pater' as 'genitor' (Malinowski 1929: 153ff) resulted in a controversy where his ethnographic account has been hotly debated over all these years. ${ }^{31}$ Just recently, in his first volume of Malinowski's biography

31. Stocking (1973) presented some strong counter-evidence to Malinowski's reports on the "spirit children". In the Yale library he found a letter to Malinowski written by his friend Billy Hancock, a trader in Kiriwina. In this letter Hancock writes "I have been gathering a lot of information since you went away about conception, birth, etc... I got a rude shock when they upset the Baloma-Waiwaia business the other evening... A baloma's life in Tuma never ceases. But I said to them you told the Doctor that it was so. They say no the Doctor told us it was like that \& we were afraid to contradict him" (Stocking 1973:6). Hancock received this information from two women; and their account was confirmed by two other female consultants. Stocking (1973:7) points out that "Hancock's evidence directly contradicted Malinowski's original account". It is interesting to note, however, that my consultants support Malinowski's reports on the spirit children and on the "myth" of conception; however, they emphasized that this is just a myth. I doubted Malinowski's claim that Trobriand men are completely ignorant of the role of the 'pater' as 'genitor' soon after my arrival in Tauwema when Kilagola, the chief of the village, castrated little boars. The Trobrianders breed pigs; thus Kilagola (and many 
Michael Young (2004) emphasises that he takes Malinowski's claim absolutely seriously (see Senft 2006:625). The topic of the "virgin birth" is mentioned throughout the biography (see Young 2004: 180, 231, 371, 387, 428, 431f., 436) and the author claims that "recent ethnographers in the Trobriands have found no reason to contradict this general statement" (Young 2004:432). However, this is rather misleading! All more recent ethnographers (and an anthropological linguist, if I may add) agree that the Trobrianders still believe in the reincarnation of the baloma. But Susan Montague (1971:365f.), ${ }^{32}$ Annette Weiner (see e.g. 1976:122) and the author of this monograph published clear challenges to the claim that the Trobriand Islanders are ignorant of the role of the 'pater' as 'genitor'. As stated elsewhere (Senft 1997a: 15ff \& 2009b: 221ff) I am convinced that Malinowski either made a gross mistake with this claim or played 'career politics' (or even took his peer group for a ride?); this conviction is based on the following reasons:

In 1983 my wife Barbara stayed with me for 11 months on the Trobriands. We then had no children, and after Barbara could speak Kilivila, the Trobriand women started to discuss contraception with her. The women of Tauwema told my wife that they had two means of contraception that are both based on a mixture of herbs that grow in the bush; to this mixture a little bit of water is added. Some women but also some men know how to prepare this fluid based on the herbal composition. Once the women had talked about this topic, I could easily verify this information with two of my male informants, namely with Weyei, the weather-magician of Tauwema, and Vapalaguyau, who both were very proud of their medical expertise and expertness which they had inherited from their ancestors; however, they did not want to show me how and with which herbs they produce this mixture (I respected their reservations and did not urge them for further information about something that is as personal and secret as magic). Anyhow, there are two modes of application for this contraceptive: Either, before the coitus the woman drips the fluid on a small sponge and then inserts it into her vagina placing it in front of her os uteri - the herbal composition is spermatocidal and thus prevents contraception. Or, the woman drinks the herbal

other men whom I observed over the years doing the same) must have had a reason why he (they) did this. With respect to this topic see also, for example, the controversy between Spiro (1982, 1992) and Kurtz $(1991,1993)$.

32. Note, however, that Montague's claim that Dr. R. L. Bellamy was also convinced "that the natives associate sexual intercourse and pregnancy" (Montague 1971:365f.) is contradicted by Bellamy's successor as Government Officer on the Trobriands, F.R. Barton (1917:75). Thanks to Eric Venbrux for pointing this out to me. 
composition in a more hydrous solution. The problem with this second mode of application is that the ratio between the herbal mixture and the water is rather delicate: the contraceptive effect of the drink may either last for a few days only or for years - and if the herbal mixture is too highly concentrated it may even cause sterility. Such a long term effect of the contraceptive almost endangered the marriage of a loving couple - however, when we returned to the Trobriands in 1989 (with our then 2 and 4 year old children), the woman who six years ago poured out her troubles to me and especially to my wife proudly presented us her two children. I would like to note here that the "yam or Dioscorea" - the most important part of the Trobriand diet - was long known by certain Mexican Indians to have a contraceptive effect. In 1983 Dr. Russell Marker ... determined the molecular structure of diosgenin, a stereoid substance with progesteronic effect derived from the yam root. Based on this information, Organon, a leading producer of contraceptive pills, uses the diosgenin from Mexican yam roots as the raw material for some of its products" (de Revai 1992) - but this is just an aside. The fact that the Trobriand Islanders know about natural contraceptives and that this knowledge is traditional is - to my mind - a clear and convincing counter-argument against Malinowski's claim which he first made in his very first publication on the Trobriands in 1916, "Baloma; the Spirits of the dead in the Trobriand Islands" (see Malinowski 1974:220-237 [=1916]), which he used like a beat of a drum to introduce his "sex book" (as he himself and his first wife called it, see Weiner 1987: xxxii), and which he elaborates in Chapter 7 of "The Sexual Life of Savages in North-Western Melanesia", namely that the Trobriand Islanders are ignorant of the role of the 'pater' as 'genitor'.

Given Malinowski's excellent command of Kilivila and the incredible amount of magical formulae he managed to collect and to translate - texts that represent secret and inherited knowledge which was up until 1983 well guarded by the experts and almost exclusively bestowed on relatives (i.e. within the matrilineal line, see Senft 1997b) - it is very hard for me to understand why the master of Trobriand ethnography did not hit upon the fact of Trobriand natural contraceptives, but took the Trobriand "myth" of conception and "virgin birth" not as a kind of ideology with the function to diminish discrimination of extramarital births and to allow obviously cuckolded men to keep their face (see Weiner 1976:122, Sprenger: 1997:61ff) - by the way, the incident Weiner reports about a man who returns after his year-long absence to his village and to his wife and who reacts extremely jealous $^{33}$ when his wife presents him with a new born child, is just

33. See Footnote 29. 
another confirmation of the fact that this man obviously knew about physical paternity.

I can only explain this - for me rather open and blunt - mistake of Malinowski's in two ways. Either he became the victim of the Trobriand Islanders' love to make fun of people - with their metalinguistic vocabulary they also differentiate the so-called "biga sopa", the lying or joking or indirect language (see Senft 2010a: Chapter 9) - and they really took him for a ride, or - but this alternative is a somewhat nasty imputation - jockeying for position, he used this "exotic" claim to promote his academic career even further. In her introduction to the latest edition of "The Sexual Life of Savages" Weiner (1987: xxvii) discusses Malinowski's relation to psychoanalysis in detail and refers to Stocking (1986) with a footnote, in which she states:

According to Stocking (pp. 32-33) Malinowski's response to psychoanalysis may have been more than intellectual. Rivers, the most eminent figure at the British anthropology, died suddenly in 1922, leaving a vacuum in leadership. Stocking suggests that because Rivers had a long interest in psychoanalysis, Malinowski in taking up psychoanalytic debates, strengthened his bid against the diffusionists William Perry and Elliot Smith, to become Rivers's successor

(Weiner 1987: xlii, Footnote 19).

The claim in 'the sex book' could then be interpreted as the final culmination of such a strategic move within academic politics (however, I want to emphasize that this assumption is nothing but a nasty imputation - an even nastier imputation would be to accuse Malinowski of having taken his peer group for a ride with this 'exotic fact').

Be that as it may, I just want to note here that I sent Michael Young, Malinowski’s authorized biographer (see Young 2004), an offprint of my (1997a) article in which I first put forward my arguments against the "virgin birth" myth and we even briefly corresponded about this issue. Young seriously disagreed with my interpretation and my nasty imputation (which he refutes as an "absurd suggestion" - in his e-mail of September 27th, 2001).

Eric Venbrux (e-mail August 15th, 2010) also argues against my imputations, pointing out that Malinowski had published the claim with respect to the father's ignorance as 'genitor' already in 1916, six years before Rivers' sudden death. Moreover, the volume "The Sexual Life of Savages in North-Western Melanesia" was published in 1929, seven years after River's death. However, Venbrux concedes that Malinowski might have tried to flatter his mentor in Australia, Baldwin Spencer and his mentors in England, Charles Seligman and James Frazer. As Young (2004:436) points out Malinowski’s 1916 essay was very well received by the leading 
anthropologists in Great Britain. In 1912 Frazer cherished Spencer's finding across Australia concerning "the notion that sexual intercourse has nothing, of necessity, to do with the procreation of children" (Frazer: 1912:72). And he continues: "All anthropologists will look forward with keen interest to the publication of Professor Spencer's fresh enquiries in this promising region" (Frazer 1912:13). Venbrux assumes that this note might have triggered Malinowski wanting to verify and even surpass Spencer. As Young (2004:436f.) points out, all three scholars were indeed impressed by Malinowski's essay and continued to support him. Seligman guaranteed the publication of the article and Spencer is acknowledged in the first footnote to "Baloma - The spirits of the dead in the Trobriand Islands" for commenting on parts of the draft of this article. Frazer even congratulated Malinowski for his achievement with this publication, despite the fact that "it had demolished his comparative method", though it confirmed "his own pet theory concerning ignorance of physiological paternity" (Young 2004: 436; see also Senft 2006: 627).

With respect to my argument that the Trobriand Islanders have natural contraceptives Venbrux notes that Malinowski's male consultants may not have had this kind of information because in his days it may have been exclusive knowledge in the female domain. However, even in these days the Trobriand Islanders raised pigs and the men certainly also castrated young boars (although one may argue that this understanding may not necessarily extend to humans)...

Finally, Venbrux comes up with another very interesting explanation of Malinowski's 'mistake' - "cognitive dissonance" as he calls it. He assumes that Malinowski's familiarity with the claim of ignorance may have been too great. He had noted it in his 1913 thesis with regard to Australian Aboriginals and his 1916 'Baloma' article was strongly influenced by Frazer and especially by Spencer and his comments on a first draft of the paper. As mentioned above, Spencer's support is acknowledged in the article and Frazer as well as Seligman are quoted. Venbrux (e-mail August 15th, 2010) elaborates on his argument as follows:

[t]he ambitious Malinowski at the beginning of his career cleverly situated himself in an important (theoretical) debate, supporting Frazer and Spencer (and Seligman) - leading figures in the discipline at the time. Note the language: 'the discoveries of Spencer and Gillen brilliantly confirmed' Hartland's suggestion/ views; and 'Sir J. G. Frazer has also given the support of his illustrious opinion to the view that ignorance of physical fatherhood was universal among early mankind'... [T] 0 attack the dogma with regard to Australia was of no use with material from the Trobriand Islands, but a similar and convincing finding elsewhere (not Australia) would be impressive. He is as important as Spencer, in 
delivering the evidence ('I desire to state some additional facts'/'I ... want ... to add some data bearing on this problem'), if not more, because his materials/data add a new dimension with a much wider reach.

And Venbrux then specifies this wider reach quoting Malinowski (1974:236 [= 1916]):

To sum up, there seems to be no doubt that if we are at all justified in speaking, of certain 'primitive' conditions of mind, the ignorance in question is such a primitive condition, and its prevalence among the Melanesians of New Guinea seems to indicate that it is a condition lasting right into much higher stages of development than it would have seemed possible to assume on the basis of Australian material only.

(Malinowski 1916:418, emphasis, E.Venbrux)

Venbrux closes his argument by pointing out that " $t]$ he final section of the Baloma article is an expansion of Malinowski's theoretical and methodological contribution to the discipline (and in that respect, in the same vain). With this explanation by Venbrux I will end my uptake of the virgin birth controversy and finish this subsection with a quote by Mark Mosko (2009:694; see also 2010:156, 164f.) who has summarized the essential idea of the Trobriand conception myth in a very Trobriand like way:

Released baloma travel initially to Tuma, the world of the dead, but eventually they return to the world of the living as waiwaia, 'spirit children', to regenerate new humans much as seed yams reproduce new yam plants.

With the presentation of the Trobriand Islanders' myths of conception and the critical discussion of the scientific reception of Malinowski's account of these myths as facts I have come to an end of my more theoretical account of Trobriand eschatology. The "religious truth" codified in this eschatology once again "reveals to man that death is not an end ... that it is possible for the survivors to keep in touch with the departed spirit" (Malinowski 1963a:258).

Before I present the wosi milamala as manifestations of these eschatological concepts I will end this chapter with a brief overview of eschatological concepts elsewhere in the Massim area and in the Pacific.

\subsection{Eschatological concepts elsewhere in the Massim area and in the Pacific}

The belief in spirits of the dead and in an underworld in which they live is relatively widespread, not only in the Massim area, but also in other regions of the Pacific. 
The classic study with respect to this belief is certainly Frazer (1913). ${ }^{34}$ With respect to the Massim Rosalind Moss (1925:34f.) points out the following:

In the North and South Massim ... there seems to be a belief in an underworld connected with caves, although the dead now usually go to some island. A deep hole forms the entrance to the Marshall Bennets underworld, and to the valley afterworld of the Wedau and Wamira of Bartle Bay, while the inhabitants of Kwato and Tube-Tube go to their island spirit-lands through caves which lead under the earth and sea, and in South Massim generally the dead pass under the earth to their new abode.

Frederick Damon (1990:26) reports that the Muyuw (or Woodlark) Islanders whose island is even further east of the Trobriands than the Marshall Bennets and who also belong to the Northern Massim believe in a

... kaluwan, which translates as 'life force', perhaps 'soul' ... some say that when a person dies, his or her kaluwan leaves the body but remains around the living for a few days. In this form it is an aluw, and is the subject of "fear". Within a few days the aluw turns into a yeluw and departs for Tum, the island just northwest of Kiriwina, which also receives the Trobriand analogue, baloma ... when yeluw go to Tum, they do not return to be recycled in new bodies. Muyuw do not believe in reincarnation, in contrast with reported Trobriand, especially northcentral Trobriand, beliefs.

Garry Trompf (1980:151) refers to Pier Amgrogio Curti’s 1861 study “The Island of Muju or Woodlark in Oceania" and its unpublished translation by D. Affleck (from Politechnico, XIV, 1962). In this early systematic ethnographic study Curti describes the journey of the Woodlark Islander's soul to its final destination, the Tuma underworld, as follows:

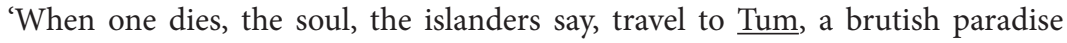
which they imagine to be a place of delight situated on the islands to the west of Woodlark ... The journey is carried out on the back of the great serpent Motetutau, He who does not freely stand on the serpent and falls in the sea is changed in to a fish or shell; but whoever stands firm finds at the entrance of Tum an inexorable old woman, who has the task of not allowing further anyone who does not carry two lines of tattooing on his arm, and whoever does not have this distinctive mark is rejected and thrown into the sea. Once having entered Tum, one enjoys all material pleasures, and has copious supplies of everything; one

34. The detailed table of contents in Frazer's study published in 1913 makes it easy to spot resemblances with Trobriand eschatology. Pertinent quotes from Frazer's study are given in Appendix I. 
lives, one dies again and yet revives, as does the drunken alcoholic who kills his reason with liquor, yet after a dream receives it back again.

Theodor Aerts (1983:4ff) points out the importance of spirits for Melanesia in general and mentions the belief in immortality of the Massim people (1983:25).

Ann Chowning (1983:421, 427) reports that the Molina of Fergusson Island in the south of the Trobriands also believe in spirits of the dead who have three lands where they can "live", one is Lotuma (which is Tuma again), the other one is a place called Bwebweso on Normanby Island, and the third one is another place in the interior of this island.

William Bromilow (1929:88ff), a pioneering Methodist missionary in the Massim area, describes the Dobuans belief in spirits and in a spirit land as follows:

Man consists of body, shadow, and spirit. The shadow has a separate existence from the body and the spirit, and remains about the house or place where the body dies. All spirits, except those of men killed and eaten, go to Bwebweso, a hill which is almost bare of trees, about twenty miles from Dobu, on Normanby Island. The spirits of those killed and eaten rise up into the clouds and take up their abode above the place where the tragedy occurred... The spirits of those killed but not eaten have to delay their journey to Bwebweso until some days have elapsed... The smell of blood must not enter the land of spirits... The spirits of all who die otherwise ... proceed without delay to a point at the southeast of Dobu, and there, resting on a tree, await the falling of a leaf. When the leaf falls the spirit alights on it and is wafted across the sea to Normanby Island. Arriving safely on the beach, the spirits climb a tree and take a last farewell of Dobu, weeping for friends and left behind. It then wipes away its tears and proceeds to Bwebweso, where the spirits of its totem have been warned of its approach by the dropping of a leaf from a particular branch of a tree. The reception of the spirits depends upon the material condition of the life spent; moral considerations do not exist. The spirits of the rich, the brave, the wellformed, the healthy are welcomed with dancing, and led over to the bridge across the chasm into everlasting life with the blest. The spirits of the poor, the emaciated through long sickness, of those who have suffered from scrofulous sores, are led by the dancers on to the bridge, which then turns into a snake, and by its wriggling precipitates the so-called bad spirits into a deep gulch, where they remain for ever and ever. The question of character or conduct does not determine the abode of the spirits.

The quotes above show that the belief in immortal spirits and in a special land in which they live can be found all over the Massim area. In his seminal volume on "Melanesian religion" Garry Trompf (1991:43ff) shows that this holds not only for the Massim area but for Melanesia as a whole. Keck and Wassmann 
(2010: 199; see also 190) report that the Yupno who live in the Finisterre Mountains in the Madang and Morobe provinces of Papua New Guinea believe in spirits of the dead who after the death of a person swim down the Yupno River into the sea to Long Island (Nomsa) where the other Yupno spirits of the dead wait for them. Jean Guiart $(2008: 24 ; 27 f f)$ points out that beliefs in spirits, in their faculty to rejuvenate, in subterranean lands of the dead and in the communication and interaction between the living and the dead can be found all over the island cultures of the Central Pacific (see also e.g. Leenhardt 1947; Monberg 1991: 112ff, Keck 2010:269). Craighill Handy (1927:65ff) shows that this holds also for eschatological ideas in Polynesian religion. And Ward Goodenough (1986:556ff) refers to the Truk and Ponape islanders' belief in spirit places in the sky and in souls of the dead that travel to their permanent abodes in the sky world. Bendann (1930:162; 164) points out that the Motu and the Koita of Papua New Guinea and the Torres Strait Islanders also believe in a land of the dead. The "casting of the skin" is discussed by Frazer (1913) and Bendann (1930). Layard (1934) describes 'the journey of the dead from the small islands of north-eastern Malekula' in Vanuatu. In this paper we find many other eschatological ideas and beliefs that are quite similar to those of the Trobriand Islanders (Layard 1934: 117-123). Eric Venbrux (in an e-mail from August 15th, 2010) points out that

Pamela Stewart and Andrew Strathern (2008: xxvi-xxix) make a comparison of 'Duna lament songs sung by women at funerals' in the Highlands of Papua New Guinea with Roman songs from antiquity - referring to Thomas Habinek (2005) - considering them as sacrifices - for the Duna with the aim to send the spirit of the dead away 'to the rock-ledges in lime stone mountains where it was to dwell with others of its kind'.

The link between death rites and the symbolism of fertility and rebirth is emphasized by Bloch and Parry (1982).

There are also many parallels of the Trobriand Islanders' eschatological ideas with Aboriginal Australian peoples' beliefs. Bendann (1930:173ff) notes that Central Australians as well as Aborigines of South Australia believe in a land of the dead, too. The research of Allan Marett (1992, 2000; 2002, 2005) on the Wangga, especially his work on the Marritjevin, Wadjiginy, Emmiyangal, Mendheyangal and Marri Ammu tribes in the Daly region in the north-west of Australia's Northern Territory and on their songs and their Walakandha dances reveals astounding parallels with the Trobriand Islanders' ideas with respect to

- the kosi (for the Daly tribes these spirits called Wunymalang do not die, are dangerous and 'live' in the bush (Marett 2000:25)), 
- the baloma (the Daly tribes refer to these spirits with the name "Walakandha") and their Tuma world of the dead (the Walakandha also 'live' on North Peron Island which - unlike Tuma - is dangerous for the living (Marett 2000:29; 2005: 183f; 234)) and

- $\quad$ with respect to the Trobriand Islanders' wosi milamala, their milamala dances and their biga baloma variety.

The Walakandha also speak an "incomprehensible ghost language" (Marett 2005:35), the songs "both embody the words of the dead and describe their actions" (Marett 1992:62) and they are given to their singers in dream by their deceased ancestors (Marett 2002: 2). ${ }^{35}$

Here I end my brief overview of eschatological concepts in the Pacific with which I have tried to show that the eschatology of the Trobriand Islanders is not as "exotic" as one may think at first sight. In the next chapter I will present the wosi milamala which are sung in the language of the spirits of the dead and which describe their carefree life in the Tuma underworld.

35. Eric Venbrux (personal communication) rightly points out that there is also a parallel between the Christian All Souls' Day and the Trobriand harvest ceremony: "In both cases the spirits of the dead come to visit the living at the time of harvest." 


\section{CHAPTER 3}

\section{The wosi milamala}

In this chapter I first characterize the wosi milamala and the biga baloma variety of Kilivila, in which these songs are sung. Then I present all the songs that I documented over the last 30 years of my field research on the Trobriand Islands. The songs are transcribed, translated and annotated.

\subsection{The biga baloma variety of Kilivila and the wosi milamala}

As pointed out above, Malinowski (1929:367) briefly mentions that many songs which are sung at the opening of and during the milamala festival "are composed by the spirits"; he documents one of these songs, the Usiyawenu song (1929:367f.), he even speaks of a "Tuma language" (1967:154), but all in all it seems that the special status of these songs escaped his attention. Bernard Baldwin (1945:202) also notes that "Malinowski himself does not seem to me to have gone into the subject very far...”. It was Baldwin who in 1945 and 1950 documented some of these songs in his publications "Usituma! Song of Heaven" and "Kadaguwai - Songs of the Trobriand Sunset Isles". Usituma - in modern Kilivila "Wosi Tuma" - can be glossed as "Tuma songs" or "songs from Tuma". The Kadaguwai songs were composed in the 1930s by Igali, a woman who “insisted it was a spirit song" (Baldwin 1950:263). Baldwin (1945:202) realized that the language in which these songs were sung "seemed not to be Boyowan [= Kilivila, G.S.] at all, but possibly some ancient and different form of it" 36 and he reports that one of his consultants told him that the Trobriand Islanders "had a secret language that they would never divulge". ${ }^{37}$ In the Introduction to this volume I reported my impression when I first heard these songs and the song

36. "Boyowa" is an old label that was used to refer to the Kilivila language.

37. See also Franklin 1972 on a secret language in the Southern Highlands of Papua New Guinea. In connection with Father Baldwin's research Glass (1986:50) speaks about "the language of song relating to Tuma”. 
accompanying drums: they sounded to me as if they came from another world. And this was actually down to the point - as we know by now.

The Trobriand Islanders distinguish not only local varieties - or dialects - of Kilivila (see Senft 1986:6ff), but also other, non-diatopical registers that I have called "situational intentional varieties". As I have pointed out elsewhere (see Senft 1986: 124ff.; 2010a: 9) I refer with this label to registers or varieties of Kilivila that are used in a given special situation and produced to pursue (a) certain intention(s). To my knowledge, Kilivila native speakers differentiate and metalinguistically label eight of these varieties, two general and six specific ones. They form the basic framework necessary for adequately describing genres in this Austronesian language, because the various genres that the Trobriand Islanders differentiate and also label metalinguistically are - generally speaking - constitutive for these situational-intentional varieties. ${ }^{38}$

As already mentioned in the previous chapters, one of these varieties is called biga baloma - the 'speech of the spirits of the dead' - or biga tommwaya - the 'old peoples' speech. The Trobriand Islanders are convinced that the biga baloma is the language spoken by the spirits of the dead in their Tuma underworld. As the alternative label of this register indicates, it is obviously an archaic variety of Kilivila which is hardly ever used in everyday discourse and conversation. If words or phrases that are characteristic for this register are used in everyday interaction, they serve the function of sociolinguistic variables which indicate high status of the speaker. As we know by now, this situational-intentional variety is used in two highly ritualized contexts: the register is constituted by specific songs which are sung during the harvest festivals and during a certain period of mourning; ${ }^{39}$ these songs are summarized under the specific genre label 'wosi milamala' - 'songs of the harvest festival'. It may well be that the Trobrianders referred in former times to these songs with the label "usi Tuma" (see Baldwin 1945) and one may speculate that they relabelled these songs into "wosi milamala" to protect their indigenous eschatological beliefs from the inquisitiveness of missionaries and anthropologists. But this is just a speculative aside. Like magical formulae many of these songs are

38. In Senft (2010a) I present, document and illustrate the Trobriand Islanders own indigenous typology of their situational-intentional varieties and their constitutive genres. Thus, this book provides a framework for, and at the same time illustrates, the "corpus inscriptionum Kiriwiniensium" Malinowski asked for (and partly founded himself) as a prerequisite "to grasp the native's point of view, his relation to life, to realise his vision of his world" (Malinowski 1922:24f).

39. Eric Venbrux (personal communication) points out that the Tiwi people from Melville and Bathurst Islands in Australia also use archaic language in their songs in increase ('harvest') and mortuary rituals. 
said to have been passed on from generation to generation with the immanent claim to preserve their linguistic form. However, my consultants told me that up till the mid 1960s individuals were able to compose milamala songs that were sung with accompanying dances to communicate with the baloma. However, these days only very few of the elderly living on the Trobriand Islands still know the meaning of these songs; but the songs and their lyrics are still passed on from members of the older to a few interested members of the younger generation - probably because of their importance for the mourning and harvest festival rituals. ${ }^{40}$ Nevertheless, this genre and with it the biga baloma/biga tommwaya register of Kilivila is highly endangered - if not already moribund (see also Senft 2010a: Chapter 4).

Every native speaker of Kilivila hearing these songs will immediately recognize that they are sung in the specific biga baloma/biga tommwaya variety of Kilivila. Baldwin (1950:256) points out that there is "a pattern of poetry or song, easier to recognize than describe, but so characteristic that most natives can recognize the diction of poetry or song even though there are no more than one or two words".

The 'wosi milamala' are intoned and ended in a very specific way, they are repeated ad libitum and they have a very characteristic melody. Baldwin (1945:202f.; see also 1950:265) characterizes these songs as follows:

There certainly is an archaic form about many of the words ... Also synonyms show up which do not appear in speech ... Then there seems to be a lot of sound shifts and vowel changes ... Grading and weakening take place where it doesn't happen in speech, no doubt influenced by the necessity of rhythm. Separate words in speech are agglutinated in song, again no doubt for the sake of rhythm, and by the same token other sounds were lengthened. The classificatory system of nouns received a further extension in song for the sake of word play. Pronominal particles are dropped before verbs. There are poetic devices ... Speech is mainly a string of verbs, poetry has strings of nouns, also, left to explain themselves like newspaper headings.

In his 1950 publication Baldwin also mentions that "[s] ounds are added at the end of lines, repetition of the final vowel, or an extra $o$ or $u$ which has no meaning, and a vocative $e$ or we may come before or after words wherever they may be, and these extras all carry notes which would not otherwise fit in" (Baldwin 1950:265).

In a somewhat overgeneralising manner (see Senft 2010a: 228ff) Baldwin (1950:265) characterizes the melodies of the wosi milamala (which he also transcribes in his 1950 publication) as being

40. Note that we could observe the same phenomenon in Europe and elsewhere during the days when the Catholic mass was celebrated in Latin: during the mass many Catholics uttered Latin sentences the meaning of which was unknown to most of them (see Senft 2003:291). 
inspired by the wailings for the dead ... There is a note of poignant yearning about all the songs, and the more touching and sad a tune is the more the people like it ... The tunes are not easy ... the slurring of the notes, which makes the melodies so touching and haunting, and which is contrived with so much charm, makes it very difficult to record the notes precisely. They sing in several keys and often in quarter tones. Harmony occurs only accidentally and is not traditional ... The timing is also difficult.

Baldwin also points out that "a song and dance like Usituma is somewhat of a saga" (Baldwin 1945:204) and emphasizes that the songs "are at least semi-religious ... the poet ... claims that the inspiration and tune are given him from Tuma" (Baldwin 1945: 206).

I realized all these special features of the wosi milamala when I started to transcribe and gloss the first songs collected in $1983 .{ }^{41}$ As briefly mentioned in the Introduction to this volume I could find 15 consultants (the youngest of which was about 30 years of age) in 1982/83 who were able to paraphrase the meaning of the words of the biga baloma in ordinary everyday modern Kilivila; many of these consultants had no teeth any more, so I often asked their children to work with me, my usual consultants and their father or mother to translate the documented songs. The elderly people first talked to their children who then repeated what was said to me; after that I tried to paraphrase the word meaning in my own words - and this process continued until the old Tauwemians nodded with their head, agreeing to my gloss (see also Senft 2003:291). By the way, this tiresome procedure of transcribing and glossing wosi milamala did not change even when I could speak Kilivila fluently years after - however, the number of consultants with whom I could do this work, dropped rather dramatically in 1998 I could find only 5 consultants with whom I could work on the wosi milamala.

In his 1945 publication Baldwin (1945:203) already lamented: "I was not able to find a native who could give me a direct, and detailed explanation of the verses". This is also true for me - none of my consultants could give me detailed information about the contents of the songs I have been collecting over all these years.

I was fascinated by the beauty of these songs from the very beginning of my field research - and in the last days of my 1983 stay I started to translate the first song cycles into German hexameters - just for fun. Back in Germany I looked a bit closer at the various stanzas which my consultants labelled as belonging to specific song cycles and realized that - taken together - they seemed to make

41. I could document wosi milamala in 1982, 1983, 1989, and 1997. 
up a story. After reading Baldwin this hypothesis seemed to be rather plausible for me. So I ordered the stanzas within their specific cycle and during my next longer field trip in 1989 I asked my consultants whether this hypothesis is true or not. All the songs I collected and glossed in 1982/83 were sung ad libitum - it was the exception when the Trobrianders sang three or more stanzas that belong to one and the same song cycle in a row. My consultants were quite astonished that I took these songs so seriously that I found out one of their "secrets" and positively confirmed my hypothesis. I had the same problem as Baldwin (1945:213) who pointed out that the "order of the verses is my own ... they were sung in the order in which they were recalled to mind". However, I had the opportunity to have my consultants confirm or correct my proposed order of the stanzas within the song cycles documented. It was only after the death of Mwasei in June 1997 that my male consultants Bulasa, Bwetadou, Mobiliuya, Mokeilobu and my female consultant Bomsamwala ${ }^{42}$ came to my house a week after the death of Mwasei and sang 5 song cycles in the sequence of stanzas in which - according to my consultants - the cycles were composed. That this is the big exception in the Trobriand Islanders' performances of these songs highlights another feature of the wosi milamala and their singers. Experts fully initiated in eschatological knowledge and thus familiar with all the allusions made in the songs to Trobriand eschatology were of course also familiar with the stories told by the songs. Therefore, skillful singers who just sang a few central stanzas of one song cycle and then decided to sing other specific stanzas of other song cycles could artistically manipulate the effect of their performance - especially with respect to their baloma audience whom they first greeted and later honored and celebrated with their songs during the milamala harvest festival. This agrees with Baldwin's (1950:263) hypothesis that "to the native acquainted with the whole story and the expression of the dance itself, [these songs and dances] must be pregnant with a far richer significance".

Before I present the wosi milamala I will first briefly document two magical formulae of Trobriand dance magic. The performance of the wosi milamala during the harvest festival is inextricably intertwined with the bisila and kaidebu dances (see 2.4 above) - and it is the multimodality of song, dance, decoration and beauty

42. Bulasa belongs to the Lukulabuta clan and was then approx. 60 years old; Bwetadou also belongs to the Lukulabuta clan and was then approx. 50 years old, Mobiliuya belongs to the Lukwasisiga clan and was then approx. 55 years old; Mokeilobu belongs to the Malasi clan and was then approx. 52 years old; and my female consultant Bomsamwala belongs to the Malasi clan and was then approximately 47 years old. 
of the dancers that result in the impressive synthesis of the arts of this complex and sophisticated ritual.

\subsection{Dance magic}

The Trobriand Islanders have always been famous for being great magicians (see, for example, Malinowski 1922;1935; 1974[=1925]; Weiner 1978;1988; Senft 2010a: Chapter 5). Until recently all Trobriand Islanders used magical formulae - "megwa" - to reach certain aims with the firm conviction that they can thus influence and control nature and the course of, and events in, their lives. The magical formula is the most important part of the magical rite(s). Besides the knowledge of how to perform the magical rite, the possession of the magical formulae guarantees that the desired effect of the magic will come true. The Trobrianders differentiate between various forms of magic; they know weather magic, black magic, healing magic, garden magic, fishing magic, dance magic, beauty magic, love magic, sailing and canoe magic, smoke magic, carving magic and magic against theft, earthquakes, witches, and sharks. There are specialists for certain kinds of magic. Expert magicians perform their rites on request and they expect betelnuts, yams, tobacco, and nowadays money for their services.

The formulae constitute another variety of Kilivila, the "biga megwa" - the magic speech. The biga megwa - which is similar to and closely related with the biga baloma - is characterized by a number of stylistic features and devices like for example alliterations, anaphora, rhymes, repetitions, metaphors, allegro rules, onomatopoetic words, and by a very special rhythm of their own. While reciting - or rather whispering and murmuring - magical formulae, the magician's accentuation of the words and phrases creates a special and characteristic rhythm. The short but clearly audible pauses the magician makes while reciting the formulae can be interpreted as text formation signals. Malinowski (1935:213) rightly praises the phonetic, rhythmic, alliterative, onomatopoetic and metaphorical effects, the various repetitions and the thus prosodically so specific characteristics of the language of magic. It is especially the phonetic, suprasegmental and poetic characteristics that mark the special status of magical formulae as a genre of its own. Moreover, with the majority of these formulae we find so-called magical words, names (of the formula or its former owners), things (like feathers and spears) and references (to the moon, to animals, to rivers, and taboos) the meaning of which are often completely unknown even to the magicians themselves.

In July 1989 Bwetadou gave me as a birthday present his specific magic for milamala dances (see: http://www.mpi.nl/people/senft-gunter/research: Wosi Bwebwe'una \& Bwetadou's dance magic). The magic is called "Memetu - Kaikwela". 
Memetu is the name of a specific flint stone with a rather sharp edge; these stones cannot be found on the Trobriand Islands. When Bwetadou performs his dance magic early in the morning before the milamala songs and dances start, he whispers the magic on the stone and then scratches with it the forehead of the dancers, the singers and the drummers. Bwetadou inherited this megwa from his father Weyei. Other former owners of this formula were his paternal uncles Gumatawa, Molukwena, Toydoku, and Kwanumyuva. The magical formula runs as follows:

Bulibwali manova, bulibwali manova, rotarota manova, rotarota manova, Bayuvekoku basilauotu.

Basile’i kenivala, kuyavala, kenivala, okadala.

Tokutokupwakupwa, Topulomgwa Bulumamgwa, Toydoku,

Bulumavau, tabugu Kwanumyuva Ageisi, ageisi,

ageisi, ageisi,

\section{kunuvatala.}

Ageisi, ageisi,

ageisi, kenivala.

Ageisi, ageisi,

ageisi, kukula.

Ageisi, ageisi,

ageisi, vilavala.

Ageisi, ageisi,

ageisi, kuvalila.

Ageisi, ageisi,

ageisi, kwebakwela.

Ageisi, ageisi,

lemgisobu.

Ageisi, ageisi.

Tokutokupwakupwa, Topulomgwa,
Big bird, big bird, little bird, little bird, Bayuvekoku-stone I will fly back. I will cut the shoulders, the hair, the shoulders, the neck. Tokutokupwakupwa, Topulomgwa, Bulumamgwa, Toydoku,

Bulumavau, my uncle Kwanumyuva.

I will rub ointment, I will rub ointment,

I will rub ointment, I will rub ointment, the hair.

I will rub ointment, I will rub ointment, I will rub ointment, the shoulders. I will rub ointment, I will rub ointment, I will rub ointment, the breast. I will rub ointment, I will rub ointment, I will rub ointment, the back. I will rub ointment, I will rub ointment, I will rub ointment, the backside. I will rub ointment, I will rub ointment, I will rub ointment, the sole of the foot.

I will rub ointment, I will rub ointment, the big toes.

I will rub ointment, I will rub ointment.

Tokutokupwakupwa, Topulomgwa, 
tabugu Tokomdaduva, bulumavau tamagu Weyei. my uncle Tokomdaduva,

the last one who died my father Weyei.

Bwetadou told me that he as a magician takes over the role of the "big bird" which he assumes to be a cassowary. In the role of this bird he rubs ointment - that is the power of his magical formula - into the dancers, singers and drummers. The formula mentions former owners of the magic. The Trobrianders assume that this list of magicians who used the formula successfully in the past increases the power and intensity of the megwa.

After Motaesa, then the dance master of Tauwema, had heard that Bwetadou presented me his magic, he also came to me and recited one of his dance magical formulae for me. The formula - which is quite similar to Bwetadou's magic - is called Megwa Ulibutu; it is for dancers only. When Motaesa performs this magic, he whispers it on the head of a dancer.

Bulibuli manova, bulibuli manova

rotarota manova,

rotarota manova.

Bayuvekuku, basekuku

o kadala - kuyavala-

o mana'ula - agaisa kuyavala.

Bagaisa, bagaisa,

bagaisa, bagaisa,

bagaisa, bagaisa,

bagaisa kuyavala.

Bagaisa, bagaisa,

bagaisa kenivala.

Bagaisa, bagaisa,

bagaisa, bagaisa,

bagaisa, bagaisa,

bagaisa etakola.

Bagaisa, bagaisa,
Big bird, big bird,

(like a) little bird (is our body),

(like a) little bird (is our body).

I rub, I apply ointment

in the neighbourhood - hair -

in the row - I rub ointment into

the hair.

I will rub ointment, I will rub

ointment,

I will rub ointment, I will rub

ointment,

I will rub ointment, I will rub

ointment,

I will rub ointment (into) the hair.

I will rub ointment, I will rub

ointment,

I will rub ointment (into) shoulder and flank.

I will rub ointment, I will rub

ointment,

I will rub ointment, I will rub

ointment,

I will rub ointment, I will rub

ointment,

I will rub ointment (into) the breast.

I will rub ointment, I will

rub ointment, 
bagaisa, bagaisa.

Bulibuli manova, bulibuli manova, rotarota manova, rotarota manova. Bayuvekuku, basekuku o kadala Kadudavasila, guyau.

Manuva agaisa.
I will rub ointment, I will rub ointment, Big bird, big bird, little bird, little bird. I rub, I apply ointment in the neighbourhood (of) Kaduvavasila, the master (of this magic). The bird (is the one) I rub ointment (into it).

Kadudavasila is one of Motaesa's patrilinear ancestors. Motaesa also told me that he assumes that the "big bird" refers to a cassowary. He could not provide any other kind of explanation of the formula.

\subsection{The wosi milamala}

In this section I first present 12 erotic song cycles. Then I present 4 sad songs, probably mourning songs, and 3 more narrative wosi milamala. The section will end with two stanzas of just two lines each belonging to two songs the names of which were still remembered by my consultants; however, with the exception of these two lines for each song the Dubweyara song and the Wosi Ye'ula were already lost in 1983. The other songs consist of a number of stanzas; some of them are called "kaila" - which can be glossed as "joining part"; they have a similar function as refrains in our songs. I will present the texts of the wosi milamala in the biga baloma variety of Kilivila and in their English translation. I will annotate the individual song cycles as comprehensively as possible, trying to avoid too much speculation and inappropriate interpretation.

Unfortunately I cannot transcribe the melodies of the songs. However, the interested reader of this book has the opportunity to access the internet and listen to most of the original data presented in this chapter. Some of the songs presented here are also video-documented. The films E 3129 and E 3130 by Irenäus Eibl-Eibesfeldt (see Eibl-Eibesfeldt \& Senft 1991) document wosi milamala and milamala dances. These data can be found under the following URL: http://www. mpi.nl/people/senft-gunter/research. Given the fact that many of the stanzas were sung at different times, the website unfortunately cannot mirror the structure of Section 3.3. Therefore it is compulsory to first read the metadata description that goes with each of these audio- and/or video-documents (see also Appendix II). I will also refer to the URL after the transcriptions of each of the song cycles. In order to access the recordings, please make sure you have a modern browser 
(a recent version of Firefox, Opera, Internet Explorer or Safari), a recent Java (JRE) plugin and the QuickTime plugin (at least version 7).

The songs were documented during rehearsals for the opening of the harvest festival in 1982 and in 1983, during the opening of the harvest festival in 1982, from an individual singer in 1989 and during the first two nights after the death of Towesei in 1997. As mentioned above, all songs were transcribed with the help of many consultants. During these transcription sessions my consultants sometimes remembered additional stanzas; they recited them and transcribed them with me. The consultants insisted that we edited all these transcriptions in such a way that slurred and/or changed (usually word-final) vowels were presented in their 'correct' citation form; sometimes the consultants also edited (parts of the) verses in a song cycle. Thus there are some differences between the transcription and what is actually heard while listening to the songs.

Whoever listens to these songs will be struck by their special quality and the extraordinary atmosphere the singers create by singing these songs. The intoning time and patterns before, during and after the actual singing of the stanzas, the pauses the singers make, the fact that the singers start and stop the singing of the stanzas ad libitum, the improvised but coordinated repetition of certain lines within a stanza, the inventory of highly characteristic melodies, the specific drumming rhythms, the joining of stanzas, the slurring of final vowels, the shortening of syllables, the insertion and modification of vowels, and the specific stress patterns that blur word boundaries make these songs quite unique. It is easy to understand that many white people living for a while on the Trobriand Islands assumed that these songs constituted a 'secret language' (see 2.3 and 3.1 above).

In what follows I present the song cycles in the transcriptions that were edited by my consultants in the way mentioned above.

\subsubsection{Wosi Bweyava}

(1) Yagila ebwadegu, kepolu biyayoyu, lakenu o kabagu, ladou - ulu valam.

(2) Kaila:

Kepolu va numa - biyayoyu. Rakenu - yegu- o kabagu. Ladou - gu wosi - ulu valam. Yagila, lubegu, ebwadegu.

(3) Bimwemya yagila. Libomatu negiyai.
Song of the yava flower (?)

The wind meets me, the waves still thunder, I lie on my bed.

Shouting - my crying.

The waves on the reef - they thunder.

I lie down - I - on my bed.

Shouting - my song - my crying.

The wind, my friend, it meets me.

It will blow softly, the wind.

The Libomatu-wind is rising in the north. 
Okega'ila mauna

ogavata nema.

(4) Yagina, igito'ina - kuto'inegu.

O kegamiya mauna minuvasi koya.

(5) Kaila:

Yagina - nubegu - igito'ina,

kuto'iunegu - ina - okegamiya -

Kuseva minuvasi koya.

(6) Yagina bivarara, numla bigurigu koya bikuvigu.

(7) Talia nevavai, kesai nikerera. Gudisi yaunuvenu!

(8) Talia bikavegu.

Varara o kwadeva va'uma - kagu vana inesi punuponu.

(9) Tasiki numanuma.

Ivai o kotumli imli keporu - ilikasi...

Yagina ivabwali.

(10) Tasiki Doveya numanuma.

Ivai Vaseda o kotumli imli keporu -

Vayayu numanuma.

Yagila Bomatu ivabwali.

(11) Inemi o Doveya Bimumya - mwemyami kegasi - mya - punuponu -

yagina bigurigu.
The cry of a bird in the sky - it is coming.

The wind, it turns me - you turn me. The voice of the bird, birds from the mountains

The wind - my friend - it turns me, you turn me - mother towards the sound of your voice. Forget the birds from the mountains.

The wind will rise, dew will wake me up the mountains are towering above me.

High tide comes in, the waves thunder.

Their children are beautiful!

The high tide will carry me.

There are companions at the beach people - my fragrant herbs girls are on the way.

We sit where the waves break.

She scratches my back roaring waves behind us in the rhythm...

The wind blows all night long.

We sit at Doveya where the waves break.

She scratches my back at Vaseda roaring waves behind us at Vayayu where the waves break. The wind Bomatu blows all night long.

Girls from Doveya it's their custom - it's your custom their voices - it's their custom they are on their way the wind wakes me up.

I tape-recorded this song cycle in 1997 after the death watch for Mwasei (see: http:// www.mpi.nl/people/senft-gunter/research - Wosi Bweyava \& Wosi Oluvekoya). The singers - Bulasa, Bwetadou, Mobiliuya, Mokivola (males), Kalivabu and Kapatu (females) - sang the song ordering the stanzas in the way in which they were 
originally composed. My consultants told me that this cycle is probably named after a flower called "Yava"; people use this fragrant flower to weave wreaths of flowers that they put on their hair or give them to other people as a sign of sympathy and friendship; women also put Yava flowers together with sweet-smelling herbs into their kwasi armlets.

The song consists of 40 lines which are arranged into 11 stanzas - including two kaila (a kaila is a kind of refrain). The first 7 stanzas of the song illustrate the inner conflicts and the deep sorrow of a baloma who has to leave his village and his beloved, especially his mother (see the second kaila, stanza 5) to go to Tuma. The home of this baloma could be Fergusson - there are no mountains on the Trobriands that could "tower" above a baloma there (see stanza 6); however, the fact that the baloma refers to a beach on Kiriwina in the last two stanzas of this song somehow contradicts this interpretation (see below). The peripetic line of this song cycle seems to be the last line of stanza 7. Here the baloma speaks of beautiful children - and refers either to the children of the baloma in Tuma or to the baloma girls there. The next stanza describes the travel to Tuma; using the advantages of a high tide, the baloma arrives at the beach of Tuma. The first thing he speaks about are smelling herbs - here it is unclear whether he refers to his own herbs or the herbs that the girls approaching him have used to make themselves smell nice or the herbs they have prepared for him, putting sulumwoya love magic on them. Stanza 9 already speaks of a we - the male baloma has found a girlfriend - and the second line of this stanza not only mentions this girl explicitly, but also indicates with a subtle remark that she is a passionate lover (see subsection 2.2. above). Nevertheless, the baloma refers to Doveya - a beach on Kiriwina Island - in the last two stanzas obviously in remembrance of love affairs he had with girls there. He addresses these girls in the last stanza and tells them that the baloma girls have the same what he calls "customs" as the girls of Kiriwina. Waking up after his first night with his baloma girlfriend because of a rising wind he sees that other girls are on their way to welcome him in the Tuma manner. Despite the fact that he is still remembering his Kiriwina girl friends the morning after his first love affair in Tuma he looks forward to meeting the girls that want to greet him as a newcomer in joyful anticipation.

The song creates a beautiful atmosphere first describing the gorgeous environment of an island in the middle of the sea where breakers hit the reef in a sea stirred up by the trade winds and the cries of birds that fill the air and then by sketching out the arrival of the baloma in Tuma and his first sexual adventure with a girl on the beach there.

A few days later I tape-recorded my male consultants Bulasa, Bwetadou, Mobiliuya and my female consultant Bomsamwala singing wosi milamala in my house, also claiming that they were ordering the stanzas in the way in which they were originally composed. They sang another version of this song cycle which 
they claimed to represent the Tauwema variant of this cycle (unfortunately this tape disintegrated and thus the original data are no longer available). Here is the Tauwema version of the Wosi Bweyava:

Wosi Bweyava

(1) Bimwe’umya, yagina.

Ribomatu negiya'i -

O kega'ila mauna

ogavata - nema.

(2) Inagu - yegu, omwe'umya. Kayaya mauna bika'iregu уеgu орипиропи.

(3) Yagina ebwadegu kepolu biyayoyu.

Rakenu o kabagu radou - unu varam.

(4) Kaila:

Keporu va ruma - biyaiyovi(yu).

Rakenu - yegu - o kabagu.

Radau - gu wosi - unu varam.

Yagina, nubegu, ibwadegu.

(5) Inemi o Doveya -

Bimya - mwemyami -

kegasi-mya-punuponu,

yagina bigurigu.

(6) Tasiki numanuma ivai okotumli

i’umli keporu ilikasi

yagina ivabwali

(7) Kaila:

Tasiki Doveya numanuma, ivai Vaseda okotumli i'umli keporu

Vayayu ilikasi yagina Bomatu ivabwali.

(8) Yagina igito'ina - kuto'inegu o kegamiya mauna, minuvasi koya.
Song of the Yava flower [Tauwema version]

It will blow softly, the wind.

The Ribomatu-wind is rising in the north.

The cry of a bird in the sky - it is coming.

My mother - as to me, my mind is clear. A sound the bird will call me I am on my way.

The wind meets me the waves still thunder, I lie on my bed. shouting - my crying.

The waves on the reef - they thunder I lie down - I - on my bed. Shouting - my song - my crying. The wind, my friend, it meets me.

Girls from Doveya it's their custom - it's your custom their voices - it's their custom they are on their way, the wind wakes me up.

We sit where the waves break she scratches my back roaring waves behind us the wind blows all night long.

We sit at Doveya where the waves break, she scratches my back at Vaseda, waves behind us - in the rhythm roaring at Vayayu the wind from the north blows all night long.

The wind it turns me - you turn me The voice of the bird, birds from the mountains. 
(9) Kaila:

Yagina nema - igito'ina kuto'inegu - ina - o kegamiya.

The wind comes - it turns me -

you turn me - mother towards the sound of your voice.

Kuseva minuvasi koya.

(10) Mimiregu - mauna yagina isivira i'umli igibwadegusimla nekuvigu.

(11) Kaila:

Mimirem dauta mauna yagina yavata isivira i’umli Bwelima igibwadegu simla gau nekuvigu

(12) Talia nevava’i, kesai nekerera gudisi-yaunuvenu. Forget the birds from the mountains. My dream - a bird the wind is turning the wave it meets me the island comes closer.

Your dream Dauta-seagull the south-easterly is turning. the wave of the Bwalimila-wind meets me the island with the Gau mountain comes closer.

The high tide hits on the reef, the waves build up and bump ashore children - the good ones.

This version of the Wosi Bweyava is very similar to the first version presented above. It consists of 46 lines which are arranged into 12 stanzas - including four kaila (a kaila is a kind of refrain). In the Tauwema version of this cycle we do not find corresponding stanzas for the stanzas 6, 8, and 9 of the first song. On the other hand, there are no correspondences for the stanzas 2, 10, and 11 of the Tauwema version in the first variant. The order of the stanzas here also differs from the order of the stanzas in the first version. The stanza 1 of the Tauwema version corresponds (more or less) with stanza 3 of the first version, stanza 3 with stanza 1, stanza 4 with stanza 2, stanza 5 with stanza 11, stanza 6 with stanza 10 , stanza 7 with stanza 10 , stanza 8 with stanza 4 , stanza 9 with stanza 5 , and stanza 12 with stanza 7 .

In content the two versions do not differ very much, either. The Tauwema variant introduces a specific seagull and a mountain named Gau on an island, but otherwise it is almost identical with the first version presented above - even though perhaps not just as subtle (and at the same time explicit) as the first version with respect to the arrival of the baloma on Tuma.

\subsubsection{Wosi Omnuyobu}

(1) Inagu yegu, Omemya, kayaya mauna bika'iregu, yegu о рuпuponu.
Song of Omnuyobu ${ }^{43}$

My mother, it's me, the wind from the north, a parrot - this bird is so beautiful.

I am on my way.

43. Omnuyobu is the name of a village in the Tuma underworld. 
(2a) Kepuru - biyayoyu.

Rakenu o kabagu, radou - unu varam. yagila-ebwadegu.

(b) Kaila:

Kepuru varuna - bioyayou. Rakeno - yegu - o kabagu, radou - wosi - unu varam. Yagila - nubegu - ebwadegu.

(3a) Yagina - igito'ina, kuto'inegu ina - okegamia Mauna - minuvasi koya.

(b) Kaila:

Yagina nema - igito'ina, kuto'inegu ina - okegamia. Kuseva minuvasi koya.

(4) Talia-nevavai, kesai nekirera. Gudisi-ya'unuvenu.

(5) Inemi Odoveya, imya mwemyami, kegasi-imya-punuponu, yagila - bigurigu.

(6) Nakivasem kaburu tavadenisi Bwegula, tasike’i Gilela, otirigau keponu.

(7) Makatoke'i Vaiga'ega, naka'ikusa - yabwedagugu.

Kasuyakesa Yabwetamya, nokwamapusa-yapunuponu.

(8) Yamanisamgwa kai, oyeremba-tau, oyeyobu - vana, Omnuyobu wosi.

(9) Bwau Metokei, mesike’i karamya, karamau - nona, kasaruba-kasa.
The waves - they heave.

I lie down on my bed, shouting - my crying. The wind - it will turn me round.

The waves on the reef - they thunder.

I lie down - I - on my bed, shouting - songs - my crying. The wind - my friend - it meets me.

The wind - it turns me you turn me - many winds bird - birds from the mountains.

The wind comes - it turns me, you turn me - many winds.

Forget the birds from the mountains.

High tide - it comes, the waves thunder. Their children - the spirits of the dead.

Inemi at the Odoveya-well she is bathing with all the others, her play - its their custom they are on their way.

the wind - it will wake me up.

Nakivasem point we two go to the Bwegula point, we sit down at the Gilela-well, me hearing the waves.

We two sit and wreath Vaigaega-blossoms, shaking them down - the wreaths of flowers wither.

We string the Yabwetamya - blossoms again, threading the flowers - they are on their way.

Yamanisamgwa - tree, my tree - I am a man, my possession - sweet smelling herbs, from Omnuyobu is this song. Rain brings the wind Metokei, it is there - the strong one, strong rains and wind - I am sad, its raining - water-curtain. 
(10) Dayerugu - vana, baiyekona - ina!

(11a) Yobwalima valu pela Mesi Mauna kala'utuna - valu, vararema isiga.

(b) Kaila:

Nemsikesa bwana, metoke'i, tau.

Kwigatesa'ina, nemokesa - kegana.

Nogwa nevararema isiga.

(12) Inemi va koya, kwivili $m$ biga.

Bigisinapu, nema nokuabusa tau.

(13) Dakabotora - vanisa iyobwi mamara.

Bauvekeya iovivila okudugana...

(14) Bwaigaleva - ina!

Ikena Dảeru.

Kagu vana ivoaki Ga'evoa.

Kagu memi...

(15) Yagina bivarara, numla bigurigu, koya biku'igu. Yagina bivarara, numla bigurigu, koya biku'igu.

(16) Inemi o Doveya, Imyamemyami Kegasimya - punuponu yagina bigurigu.

(17a) Tasikini Numanuma Iwai, Ikotu'mli, imli, kepolu, ilikasi, yagina ivabwali.

(b) Kaila:

Tasikidoveya numanuma,
Dayerugu - sweet smelling herbs, I yearn for you - oh mother!

I guard the village for the Mesi- and the Mauna-star day and night - the village, day is dawning.

She is sleeping in the house, he holds her in his arms, the man. You wake her up, she wards you off - she says no. already day is dawning. Inemi from the mountains, foreign is your language. She makes fun, she comes a gift from a man

Our house - the door it is low tide.

I walk the reef looking for shells on the beach...

Bwaigaleva - oh mother!

She is beautiful, Da'eru.

My sweet smelling herbs -

I sleep with Gaevoa-herbs near-by.

My dreams...

The wind blows strongly, there is much dew, the mountain is high. The wind blows strongly, there is much dew, the mountain is high.

Inemi at the Doveya-well Imyamemyami and Kegasi it's their custom - they are on their way wind raises.

We two meet in Numanuma Iwai-wind, Ikotumli-wind, waves, surges, breakers, wind blowing at night.

Tasikidoveya-village at the right 
Ivai Vaseda, Okotu'mli, imli kepolu Vayayu - ilikasi, yagina Bomatu ivabwali.

Miweyobu - ina! -

Nokudusa - inekudu.

Kusi'umisa kutawenusa,

Rurumri - bwuita.

(19) Bime'mya yagina, Ribomatu negiai, okega'ila mauna, ogavata nema.
Ivai-wind in Vaseda, Okotumli-wind, waves, surges in Vayayu - breakers, Bomatu-wind blowing at night.

Miweyobu - oh mother! Her sweet smelling herbs and flowers - so many.

You all sit together and put them in your hair,

Rurumri-wind - wreaths of flowers

Bime'mya-wind,

Ribomatu-wind - it is blowing strong, it makes the cock crow, the fall wind is coming.

In 1989 Bwetadou, a then 38 year old man of the Lukulabuta clan, sang this song and I could document it on tape (see: http://www.mpi.nl/people/senft-gunter/ research - Wosi Omnuyobu). He provided me all the information with respect to the names mentioned in this song. The order of the stanzas is Bwetadou's.

As already mentioned, Omnuyobu is the name of a village in the Tuma underworld. This song cycle belongs to and is sung by the female baloma in Tuma. I do not know whether there are also songs that are performed by men only.

All in all I could document 23 stanzas. However, Bwetadou told me that the stanzas that I differentiated as Nos. $2 \mathrm{a} \& \mathrm{~b}, 3 \mathrm{a} \& \mathrm{~b}, 11 \mathrm{a} \& \mathrm{~b}$ and $17 \mathrm{a} \& \mathrm{~b}$ represent variants of the song cycle. In one variant only the "a"-stanzas are sung, in the other variant only the "b" stanzas are sung. Thus, the "a"-variant consists of 74 lines which are arranged into 19 stanzas, and the "b"-variant consists of 75 lines which are arranged into 19 stanzas as well.

Note that the stanzas $2 \mathrm{~b}$ and 4 of the Wosi Omnuyobu are identical with the stanzas 2 and 7 of the first variant of the Wosi Bweyava, and the stanzas 3a and $3 \mathrm{~b}$ are almost identical with the stanzas 4 and 5 of the first variant of the Wosi Bweyava. This may indicate that the composers of these songs use (probably subconsciously) stanzas from other songs as kind of set pieces which they use in composing their own songs.

In the Wosi Omnuyobu a female baloma experiences the inner conflicts and the deep sorrow realizing that she has to leave her village and her mother. The last line of stanza 4 is the peripetic line of this song cycle. The baloma mentions the beautiful children - and refers either to the children of the baloma in Tuma or to the baloma boys there.

The next stanza describes already a scene in the Tuma underworld. Iremi is bathing with other girls at the Odeveya well preparing themselves for their playing around later. Note that in ordinary Kilivila the name for "play" is "masawa"; this 
expression has also strong connotations with "love play"; I am convinced that this also holds for the "play" referred to in stanza 5. The new female spirit slept at the beach of Tuma. Waking up because of a rising wind she sees that Iremi and the other girls are on their way to welcome her as a new member within her group of baloma. These girls will take her to their village where she will be welcomed by all the other baloma living there.

Stanza 6 describes a scene at Tuma - two (geographic) points - Nakivasem and Bwegula - are mentioned. It seems that the first walk the new baloma takes together with another female baloma is described - moodily the newcomer listens to the sounds of the waves clashing at the reef at the Gilela well. Remember that the stone with the mould full of water where Topileta opens the eyes of newcoming baloma so that they can see the Tuma underworld is called "gilela va sopi" (see 2.1 above).

In stanza 7 the new baloma together with another female spirit is shaking Vaiga'ega-blossoms from a tree; they collect them and together with Yabwetamyablossoms string them on threads to wear these wreaths of flowers as decoration on their hair - in joyful anticipation of them "who are on their way" - a subtle hint to a group of young men on their way to visit the female baloma in their village Omnuyobu.

The next stanza introduces a male protagonist. He refers to a special tree boasting that he is a man who is in the possession of vana herbs; these herbs are usually the carriers of love magic. Then he explicitly states that he is singing a stanza from a song that belongs to the female baloma in Tuma - probably indicating that he intends to visit someone in Omnuyobu.

In stanza 9 we learn that there is a rainy season in the Tuma underworld, too. Here the female spirit who just arrived is complaining about the depressing weather conditions which enhance her sadness.

In the next stanza she calls upon Dayerugu - this is the name of a woman, probably her mother. Then she mentions vana herbs. It remains unclear, though, whether the next sentence means that she yearns for her mother or for these herbs that carry love magic.

Stanza 11 of the "a"-version mentions a guardian of the village and two stars - Bwetadou did not know what this stanza alludes to.

Stanza 11 of the "b"-version is more explicit. The female spirit has a house by now. She is sleeping in the arms of a man. He wakes her up propositioning, but she wards him off. The last line may indicate that this may have happened more than once during this night which will soon come to its end.

In the next stanza we learn that the name of the baloma is Inemi and that she comes "from the mountains" - that is to say from one of the D'Entrecasteaux Islands, probably from Fergusson. This would explain why it is said that she has a 
"foreign" language - however, this line may also indicate that the male Trobriand baloma is not used to be warded off by the other much more 'easy' female baloma. This kind of interpretation gets some plausibility with the next line which tells us that she was only joking and is already approaching the man - from whom she will get a special gift now.

Stanza 13 shows that there are also everyday routines for women to be done in the Tuma underworld, like walking on the reef looking for shells to boil for a meal.

The next stanza again has a male baloma as its protagonist. He praises the beauty of two other women in Tuma, Bwaigaleva and Da'eru. He has already prepared his herbs - it is unclear whether the term Gaevoa refers to the herbs or to the magic that he has put on them - with which he wants to seduce these women the following day: He is looking forward to what will happen then with great expectations - however, for the time being just in his dreams.

Stanza 15 provides an atmospheric description of this windy but obviously quite romantic night.

In the next stanza we are told that three girls, Inemi together with Imyamemyami and Kegasi take a bath at the Doveya well; it is unclear whether it is their custom to bath every morning there - in stanza 5 we already learned that Inema was bathing there - or whether they take a bath there to afterwards follow their custom looking for attractive male baloma on their way...

Stanza 17 of the "a"-version reports about a rendezvous of two baloma in the village Numanuma; they spend a wild-romantic night together, a night of strong winds and heavy waves breaking at the reef.

Stanza 17 of the "b"-version provides yet another atmospheric picture of the village Tasikidoveya at nightfall. This village has two sectors, Vaseda and Vayayu.

Stanza 18 reports on the sweet smelling flowers and herbs of a girl called Miweyobu. She is sitting together with other girls making wreaths of flowers and putting them in their hair - preparing for the night to come.

The last stanza pictures this windy night that ends with the crowing of a cock.

The Wosi Omnuyobu cycle provides some insight into the ideas female Trobriand Islanders have about Tuma. We learn that there is a special village for female baloma, Omnuyobu. The cycle mentions two other villages, Numanuma and Tasikidoveya and local landmarks like wells and points.

It describes the arrival of a female baloma in Tuma and how she gradually settles into her new surroundings - getting used to the life and the customs of the female baloma with all their love affairs and their ways of preparing for their dates but also with their daily routines like walking on the reef looking for shells to boil for a meal.

The songs create a dense atmospheric and highly romantic picture of the nights in the Tuma underworld. 


\subsubsection{Wosi Oruvekoya}

(1) Kwatuyavesa waga, rakeda milaveta.

(2) Igineda-igibwau, kwaturaema - tevau.

(3) Kwatuyavesa waga, rakeda milaveta.

(4) Isirara - Namgereva-Budibudi.

Kaugepwasa waga nagega milaveta.

(5) Kusiunisa ina, bukagonusa buita.

Bisuya, Namirumeru,

biruveyem kunugu.

(6) Kumnabegu ina, kusiunisa tau.

Bukwasana guwosi.

Bigoegu vaponu.

(7) Mbutumgwa venu, Miliobu - vaogu, bokone'isa tau. Kusiunegu siporu.

(8) Sikevai, nubegu, mkwebwau urata, rokumavai va'ogu bidam valuekoya.

(9) Kaila:

Sikevai nubegu kwatudelisa napunuропи, kulimatusa biga.

Basikemrura, bivanisegu tadou.

Okunevotu bukwiyayema tevau.

Mkwebwau, urata, rokumevai vavogu bidam varuvekoya.

\section{Oruvekoya Song}

Turn round the sail of the canoe, its course is to the open sea

Our wind - very strong, it blows us off the land - men.

Turn round the canoe's sail, its road is to the open sea.

A girl with two men - Namgereva Budibud Island (far away). The wrecking of the canoe we wonder about it at the open sea.

You sit together girls, you make wreaths of flowers. She will string the flowers, Namirumeru, she will put them in her hair.

Stay with me girls, you stay with the man. You will like my song. She'll cry for me with joy between waves and sand.

The noise of the village, Miliobu-Yamshouse - my body, They will look for the man You sit and sing songs.

Their flirting, my friend, the singing of the young men, her liking of my body it will get quiet in Valuekoya.

Their flirting, my friend you walk in line young girls, you use the right language. I will sit between the two points, she will refute me (Bwe)Tadou. In front of the beach you will love the men.

Your singing, young men, her liking of my body it will be quiet at Varuvekoya. 
(10) Kwatupelemgwa venu,

be'ura'emgwa nogu,

okega'ila nogu.

Bimyegu, unata.

(11) Kapisim, gwadi,

bakina koya.

Yoyuvanogu varam, gunuvenu.
You change the place of your village, it will open my mind, it will change my mind.

She whispers to me, young man.

I am sorry, child,

I will see the mountain.

My mind remembers the crying,

my village.

I tape-recorded this song cycle in 1997 after the death watch for Mwasei (see: http:// www.mpi.nl/people/senft-gunter/research - Wosi Opesi \& Wosi Oruvekoya \& Wosi Diyapani). The singers - the four men Bulasa (55 years of age), Bwetadou ( 45 years of age), Mobiliuya (55 years of age), Mokivola (50 years of age), and the two women Kalivabu (51 years of age) and Kapatu (48 years of age) - sang the song ordering the stanzas in the way in which they were originally composed (see also Senft 2010a: 33ff).

The song is named after a place close to the Tuyabwau, a fresh water well in the south-west of Tauwema village on Kaile'una Island (see Senft 2008b: 349, Figure 5). My consultants have no idea why this place name is associated with this cycle.

The Wosi Oruvekoya is a song about a shipwreck, the death of the canoe crew and the thoughts of the baloma of one of the sailors - obviously a young unmarried man who has died during the shipwreck - just after his arrival in Tuma. It consists of 42 lines which are arranged into 11 stanzas (including one kaila).

The first three stanzas report the problems of a canoe crew who got into rough seas with strong winds. The canoe is blown away from the Trobriand Islands - far out into the open sea. The crew wanted to turn round - however, to do this in a big "masawa" canoe they would have had take down the sail, take the mast from the prow to the stern, put it up again and hoist the sail - so that the former prow becomes the stern, and the former stern becomes the prow. Masawa canoes are big outrigger canoes - it is essential for sailing these canoes that the outrigger always remains windwards. Such a manoeuvre is very difficult and almost impossible under bad weather conditions (see Senft 2009c).

Stanza 4 reports the shipwreck; however, it seems that two men of the crew had a love affair with one and the same girl - Namgereva. Now, just before their sure death they wonder about their affair and what will happen with this girl after they have died. The island Budibudi is mentioned - baloma from Kaile'una and Kiriwina pass this island on their way to Tuma.

The next stanza sketches a scene typical for activities of girls during their leisure time. They sit together and make wreaths of flowers which they put on their heads as a special sweet smelling decoration. The name of another girl is 
mentioned here, Namirumeru, obviously another sweetheart of the baloma of the shipwrecked and drowned man who sings this song.

Stanza 6 presents the singer's futile plea to the girls he is thinking of, especially to one of them to stay with him. He is sure that he could have seduced her with his song and imagines a scene of passionate love that would have make her cry for him with joy at the beach.

In the next stanza the singer remembers village life. He knows that the men living in his village sent out canoes to search for the shipwrecked party; meanwhile, the girls were sitting together singing some of their sad and sentimental songs.

Nevertheless, they also flirted with the other young men who came and joined them in singing the wosi gita (see Senft 2010a: 229f.). The singer of the song is yet convinced that his sweetheart will remember how much she liked him - but alas he has died and so it will now be quiet in Valuekoya - probably the name of a spot where he and his girlfriend used to meet each other.

Stanza 9 looks back to the singer's old life but also forward to his new life as a baloma in Tuma. He reminds the baloma of one of his crew members who has arrived in Tuma together with him of the flirting behavior of the girls: At the same time he imagines that he soon will sit somewhere between the two geographic points of the Tuma underworld. Here we learn that the singer's name is Bwetadou. He knows that his girl friend cannot but refute him now as a lover and that she will have love affairs with other men after his death. Still being somehow between the two worlds - the world of the living and the world of the dead - he bewails the loss of this girl.

In the next stanza he realizes that when she will leave her village to live with another man as his wife he will have to change his mind and turn towards the baloma girls in the Tuma underworld.

In the last stanza the man states again that he feels sorry about his fate, about what has happened and what will happen - and he points out that he still remembers how he was bewailed only a few days ago in his village. This might be an indication that baloma of people who have died somewhere else will nevertheless be able to first go back to their village to witness the mourning ceremonies there before they go to Tuma.

\subsubsection{Wosi Verai}

(1) Naukwelibu vivina davegu vaponu bwekaya vetupa.

(2) Kaila:

Naukwelibu nuguta bwekasa, tamada
The sorrow of the girl calling me between waves and sand going to him, he refuses her.

The sorrow my brother good, our father 
karara inada

davegu vaponu -

bwekaya vetupa

(3) Nabwadasi kuoli bavekota Omyuva.

(4) Sirapugu vivina manauligu deli bweyuviyavi vana vivina -

kavekota Omyuva.

(5) Nabwadasi kuolibavekota Omyuva.

(6) Bweya'ura kuoli. Guwaga kadeni, vaoli bigana.

(7) Kevana-biponu Vanubi, nuagu yoima nogu.

(8) Sideni mawaga waga duoliwagana Bweyova.

(9) Kaila:

Nakasa wagana. Kugisi duoli wagana Bweyova sideni mawaga.

(10) Pulupolu biyoyu kwitanisa bipolu kagu vana biyoyu.

(11) Kaila:

Kwegunigu gabusa ineoli $m$ yegu badiyeta - biponu -

punuira gwadi va moi.

(12) Pulupolu biyoyu kwitanisa bipolu kagu vana biyoyu. and our mother

calling me between waves and sand going to him, he refuses her.

Our friend paddles him over I arrive at Omyuva.

Me being tricked by a girl my feeling is the same very hot are the sweet smelling herbs of the girl we arrive at Omyuva.

Our friend paddles over I arrive at Omyuva.

Bweya'ura the canoe paddles over.

My canoe Kadeni, it brings the news.

Tuning in - it will continue it loves it, my mind it comes back to my mind.

They sit in line in our canoe the canoe Duoli the canoe of Bweyova.

Ashore and in line are the canoes. You see Duoli the canoe of Bweyova they sit in line in our canoe.

Loudly will it be heard expose it - it will continue my fragrant herbs will be known.

Wake me up Gabusa-flower fragrant Ineoli-leaves reach me good-smelling Badiyeta-leaves it will continue the good child on the mat. Loudly will it be heard expose it - it will continue my fragrant herbs will be known.

I video-recorded my male consultants Bulasa (55 years of age), Bwetadou (45 years of age), Mobiliuya (55 years of age); Mokeilobu (52 years of age) and 
my female consultant Bomsamwala (47 years of age) singing the Wosi Verai in my house on June 13th, 1997, a few days after Mwasei had died (see: http:// www.mpi.nl/people/senft-gunter/research - Wosi Verai \& Wosi Dubeoli \& Wosi Dubeyava; unfortunately, the recording only starts after stanza 4). My consultants claimed that they were singing the stanzas in the order in which they were originally composed. The song consists of 39 lines which are arranged into 12 stanzas (including two refrain-like kaila). My consultants did not know what the term Verai means.

The protagonist of this song is a young male baloma. Stanzas 1 and 2 report that he still remembers his girlfriend's and his parents' mourning for him. They went to the beach - most probably on an island from which one can see Tuma and called him, but as a baloma living in the Tuma underworld he had to refute their attempts, especially the attempts of his girlfriend to contact him.

Stanza 3 very abruptly changes the topic. In a rather elliptic way we learn that some of the protagonist's friends paddle him over to Omyuva. This is one of the few cases where I can elaborate a bit on the allusions that are made here.

The first allusion made here refers to a famous myth: Every Trobriand Islander still knows that Omyuva is the village in which Imdeduya lived. This woman is the heroine of a famous myth that is named after her: The myth describes the journey of Yolina who paddles through the Trobriand archipelago in search of Imdeduya. He had heard of her extraordinary beauty and wants to find and marry her. Wherever he lands and goes ashore the chief of the respective village organizes a big feast and offers him his daughter for marriage. He declines all these offers continuing his journey until he reaches the village where Imdeduya lives. After some complications and with the help of some magic he finally manages to marry her and stays with her and her parents in her village. Imdeduya gives birth to a boy and a girl. After some time Yolina and Imdeduya quarrel about their children and about Yolina's relationship with one of his wife's sisters. Yolina decides to leave her. One night he takes his magic canoe and starts paddling home to his village. Imdeduya notices him leaving and tries to call him back with a magic spell, but he reacts with countermagic. She climbs up a tree to see him better. When he has vanished at the horizon she falls down, breaks her neck and dies. Yolina returns home to his village and stays there. After her death Imdeduya metamorphosed into the moon; Yolina, however, metamorphosed into the sun after his death (see Senft 2008a).

The second connotation of these two lines have to do with the famous and highly ritualized "Kula" trade, an exchange of shell valuables that covers a wide area of the Melanesian part of the Pacific (see Malinowski 1922, Leach \& Leach 1983; Persson 1999). Woodlark is one of the centers of this trade. It is very 
much likely that these two lines of stanza 3 announce that the young baloma is preparing a kula expedition from Tuma to Woodlark Island. My consultants told me that the baloma men - like most of the other Trobriand Islanders' - love to do Kula with other baloma who formerly lived in places that are included in this famous trade system.

In stanza 4 the baloma tells us that he still remembers how he was tricked by a beautiful girl and her sweet smelling herbs with the bubwayayta love magic to forget his girl friend and his parents. This hints at the fact that he has only recently arrived in the Tuma underworld. However, now he arrives at Omyuva.

Stanza 5 is a repeat of stanza 3. In stanza 6 we first learn that the canoe in which he was paddled to Omyuva is called Bwey'ura. However, we are also told that the young baloma uses his canoe Kadeni to bring the news to the baloma from Omyuva that he and his new friends plan doing a Kula expedition. This is a puzzle my consultants could not resolve.

Stanza 7 reports that the baloma gets tuned into his former habits of doing these expeditions again; he remembers how he enjoyed these trips and the exchange of the shell valuables.

In the next stanza we are introduced to the baloma Kula party. The men sit in line in their canoe Duoli, a canoe from Boyowa, that is, from Kiriwina Island.

Stanza 9 sees the Kula party shortly after their arrival at the beach of Omyuva. The canoes are already pushed and pulled ashore and put in line. The crew of the Duoli canoe is sitting in the boat preparing for the contact with their Kula partners. It is pointed out that this canoe - with its obviously rich and beautiful decoration - catches the eye of everybody.

Stanza 10 boasts that the word will soon spread that the Kula parties have arrived. The baloma then are plagued by their Omyuva trade partners to show them their Kula valuables, the red soulava necklaces made of spondylus shells and the mwali shell armbands. The young baloma - enjoying the Kula trade - also looks forward to the amorous part of this expedition: he is sure that he will seduce many girls of Omyuva, the home of the beautiful Imdeduya - with the help of his sweet smelling herbs and his love magic.

Stanza 11 tells us that his bundle of herbs consists of Gabusa flowers, Ineoliand Badiyeta leaves - and with his magic put on these bouquets of smells he is indeed successful - a good young girl is lying on his mat.

The last stanza is a repeat of stanza 10.

Thus, the Wosi Verai reports on a Kula expedition of the baloma of the Tuma underworld to Woodlark Island. The song manages to convey something about the pride, the self-esteem and the narcissism of the Kula traders - be they baloma or not. 


\subsubsection{Wosi Onegava}

(1) Setoyegu inagu, ilamgu Bweyova, laveyami gukwauya.

(2) Sana unumwedudu venu - magubweyava yobu nitugwai.

(3) Iyogibu tamagu, bavadara gubua, okasana Bomatu.

(4) Masaguma vana, okeoli nemya.

(5) Vana bivoli vom.

(6) Bavasaki gubwuita, egaega Bomatu, vavoligu vivila.

(7) Bwerara - magubwuita bweyava o kunugu, bwenisi, vivinai.

(8) Iva’oli vivina, ivarara Bomatu, ivatusi vagana.

(9) Kominegu, tamagu, mivetupa - unata veyumegu nubegu.

(10) Venubegu Voli, inubegu Voli!

(11) Kasabava mwanamigina ya'uverara.

(12) Varara - To'unata bikasa o migim.

Bwenisi - kegayobu.

(13) Rabige'utu, bwadagu, rabigebwena rivana bigideyobu - nuagu.

(14) Bikamapu tabugu, bikatoi varam, vasanegu biponu.
Song of the Canoe Onegava

I wish my mother was here, I cry for Boyowa, you decorated my basket.

Pointing to tobacco and venu - herbs - my belongings and caring for my child.

He is sad my father, I stroll around with my betelnut, we will reunite in the north.

I put them in my armband, the herbs, the Keoli - herbs in the Nemya bracelet.

Vana - herbs they will touch your body. I pick my wreath of flowers, the earth quakes in the north, my wife - a girl.

Blossoming soon - my wreath of flowers he puts it on my head, they like him, the girls.

He goes to her, to the girl, she hides in the north he recognizes her at the beach.

I quarrel with my fate, my father, unrequited love - this man he comes back with my girl - friend.

My friend Voli, my friend Voli!

Get in rows for the dance, for the game faces - pandanus - leaves flutter in the wind.

She is hiding - To'unata in the row with the others he will appear before you.

He is beautiful - good words.

His speech, my brother, his well chosen words they will hurt me - I know.

We two will be one my friend, her crying continues, he gives me the betelnut. 
(15) Ulivorigu bwena, m'kwegamya wosi.

(16) Kegamya vivina, keganena vatova, nemvemya guwosi.

(17) Kaila:

Kegamya Vevara, kegimwedudu Bomatu.

(18) Kaila:

Mikevana verara, mikamya Bomatu bukweganisa va baku.

Mikevana - vivina mikamya - varam kweganisa gu'osi.

(20) Mikeyobu vina, kumisa wosi, yamwemya, vana.

(21) Inekudu ineoli, titavagu - buva banagisa Tuma!

(22) Bigideoli, tau. Bigidemapu - vana.

(23) Veyobu - kagu kauya vadudu vivina, vetaki o migim!

(24) Kuvadunu-tuaguvasanegu kiyaya bavetaki vamwana!

(25) Butula Onegova. M'yegu. Bonokum todeni, ivina'i tokasa okwadeva.

(26) Basila o negova, bakipu ke'urata, bakau akwemya!

(27) Vatoa kagu kauya vadudu agu mwali yevata o kwadeva.
My body is beautiful, you are humming a song.

Humming girl, the air begins, she is practising my song.

Humming in Vevara, whispering in the north.

Your singing in Vevara, your humming in the north they will not like it in the midst of their village.

Your singing - girl your humming - tears they did not like my song. You carry the children, you girls, you practice singing the songs, you sway your hips, herbs are in your bracelets.

To bind the bunch of herbs - they are moved, I long for her - my betelnut I will go there and see: Tuma! She longs for him, for the man. He wants her - sweet smelling herbs in the bracelet.

Veyobu - my little basket walking with the girls, playing the game - your face is so beautiful!

Come you two - you friends I give what I have I like playing this game!

This is the song of the canoe Onegava. The wind blows. With herbs in their bracelets, there they are standing, the girls, in a row they are standing at the beach.

I will sit in the canoe, I will count the crew, I will dare it and hum my song.

Putting down my basket they come for my mwali-shells they watch them there at the beach 
I tape-recorded this song cycle on the 23rd of January 1983 (see: http://www.mpi.nl/ people/senft-gunter/research - Wosi Onegawa \& Wosi Pilugwana/Wosi Pilugwana $\&$ Wosi Onegava). A group of elderly women was sitting on mats on the central village place singing wosi milamala; they did it just for the fun of it. They first sang the Wosi Onegava and then the Wosi Pilugwana (see below). The Wosi Onegava consists of 75 lines which are arranged into 27 stanzas (including two kaila; see also Senft 2010a:35ff). Onegava is the name of a big masawa canoe; this indicates that the cycle deals with the Kula trade. However, most of the stanzas of this song describe the love affair of a young baloma couple; it is only the last three stanzas that topicalize the Kula trade - (which was also a theme of the Wosi Verai presented in the previous subsection).

In this song some stanzas represent the singing of a female baloma and some stanzas represent the singing of a male baloma; moreover two stanzas are sung by the female baloma's former husband, - these stanzas alternate constituting a kind of antiphony.

The first 5 stanzas are sung by a young female baloma. She has just arrived in Tuma and still cries for her mother and the island Boyowa (i.e. Kiriwina), where she lived. She remembers that she saw her mother decorating the basket with her belongings to take with her to Tuma while she was bewailed by her friends. Her mother also made sure that the basket was filled with tobacco and venu-herbs and she knows that she will care for her child she had to forsake. She also remembers the sadness of her father now that she is strolling around on Tuma waiting for Topileta to give him the betelnut so that he ushers her into the Tuma underworld. She comforts herself with the thought that sooner or later she will be reunited with her parents in the north. "The north" is an often used euphemism for the Tuma underworld. In stanza 5 she puts her herbs into her armband, being sure that the magic will have its effect on an addressee who is yet unknown to her.

In stanza 6 a male baloma gets himself ready for welcoming a new baloma who was announced by the usual earthquake (see 2.2 above). Decorated with a wreath of flowers he sees her and decides to make this young girlish woman his wife.

In stanza 7 the female baloma reports that the male spirit presents her his wreath of flower and puts it on her head. She notices that the other girls like him very much.

In the next stanza we learn that the man approaches the girl; she playfully hides from him somewhere in the Tuma underworld, but he finds her and recognizes her (in the Biblical sense) at the beach.

However, in stanza 9 the girl already complains about the man she has just fell in love with; she is afraid he may not be a faithful and true partner when she sees him coming to her accompanied by her old girl friend. Nevertheless, in stanza 10 she joyfully greets her old friend Voli. 
In stanza 11 the girls are asked to form rows for a specific dance game, in which man and women dance in rows, approaching and going away from each other. During this dance they will see many faces of beautiful male baloma passing by. The pandanus streamers mentioned here indicate the swiftness, the lightness, the ease and the grace of the dancing baloma.

Stanza 12 tells us that the girl is hiding again - but someone tells her that To'unata, another man, is dancing in the row and that sooner or later he will appear in front of her. To'unata is a beautiful man and he approaches her using the right words for a newcomer to Tuma.

In the next stanza she praises To'unata's rhetoric; nevertheless, she foresees that his words will hurt her - she still thinks of her beloved ones she had to forsake in Kiriwina.

In stanza 14 To'unata declares himself and despite the fact that she is still crying he gives her his betelnut - with his love magic put on it. Her affair with To'unata has started.

In the next stanza she has realized again that she is a beautiful woman - she is with To'unata who is humming a song.

Stanza 16 tells us that he has noticed that she is practicing humming his song.

The first kaila (stanza 17) takes up the topic of the two lovers jointly humming To'unata's song in a place called Vevara - and mentions the whispering that can be heard in Tuma afterwards. And the second kaila (stanza 18) mentions that the two lovers now also sing and hum this song wherever they are in Tuma and admonishes the two lovers that this public demonstration of their love for each other is perceived by the other baloma as unseemly or even as indecent. On the Trobriands loving married couples do not exchange any signs of tenderness like holding hands, kissing in public, or embracing each other, not even after some time of having been parted from one another. The relationship of a wife and her husband seems to be rather detached, at least in the eyes of Westerners (see Senft 1995:220).

And indeed, in stanza 19 we hear that the girl singing and humming To'unata's song is probably reprimanded to behave properly by the other baloma - her innocent habit ends in tears, and To'unata concludes that the other baloma did not like his song.

In stanza 20 To'unata praises the girls who not only carry the children, give birth to them and look after them, but also practice the songs of the baloma, are eager to impress the male spirits with their beauty and ready to seduce them with their love magic.

The next stanza continues this praise, pointing out how carefully the girls bind their vana-herbs together. However, it is unclear whether these are still To'unata's words. It may well be that the former husband of To'unata's new girl-friend remembers his wife. He longs for her - takes his betelnut with his own love magic 
put on it and visits his former wife in Tuma. The last line of this stanza makes this interpretation rather plausible - neither the young woman nor To'unuta have to go to Tuma - they are already there.

In stanza 22 we learn that the female baloma longs for her man and that he wants to have her - with her sweet smelling herbs in her armbands.

In the next stanza the visitor addresses his former wife - her name is Veyobu, but his pet name for her is "little basket". He sees her walking with the other girls "playing their game" in the Tuma underworld and is stuck again by the beauty of her face.

In stanza 24 Veyobu addresses the two men, asks them to come to her as friends - she will give her love to both of them and confesses that she really likes playing these games...

With stanza 25 the love story between Veyobu and To'unata has come to an end - and we are reminded that this is the song of a Kula canoe. Time has come to do these Kula expeditions to other islands where the canoe crews will exchange their shell necklaces and armbands with their Kula partners. The girls of the Tuma underworld are standing at the beach in their full attire watching the male spirits preparing their canoes to sail away.

In stanza 26 To'unata presents himself as one of the toliwaga, the canoeowners; he sits in his canoe, counts his crew and hums his song again, this time in joyful anticipation of the Kula trip.

In the last stanza the crew has arrived at their destination. To'unata puts down his basket with his shell valuables and sees his Kula partners coming to barter for his mwali shell armbands. All the inhabitants of the nearby village where his Kula partners live watch them carefully.

\subsubsection{Wosi Pilugwana}

(1) Vadenisa Bwiyariga yakayobu yamvedoku.

(2) Kapisina Kwe'ineoli gidiviligu

Neoli.

(3) Kumidorigu mweyuva mamidorim mweyuva vana - simgeori.

(4) Sogu Yaurivori ka'uvamapu maka'i kakamapu mabwita.
Song of the canoe Pilugwana

They go with Bwiyariga,

Yakayobu-herbs smell - and there's humming.

Pain is what Kwe'ineoli causes, the love magic, pain - and change in the course of time the love magic Ne'oli.

My hot spice -

how good is that, how hot this spice is and sweet smelling herbs - very fresh.

Beloved Yaurivori

we meet each other words of love, we exchange our wreaths of flowers. 
(5) Natokwabu ugwarai nukulibusa, Pilugwana.

(6) Kemyovau, ugwenegubakana'ira o papala.
Natokwabu goes there - she halts you push it out into the sea, the canoe Pilugwana.

New canoe, my canoe soon I will lie on the outrigger platform.

As mentioned in the previous subsection, I tape-recorded this song cycle on the 23rd of January 1983 (see: http://www.mpi.nl/people/senft-gunter/research - Wosi Onegawa \& Wosi Pilugwana/Wosi Pilugwana \& Wosi Onegava). A group of elderly women was sitting on mats on the central village place singing wosi milamala; they did it just for the fun of it. The Wosi Pilugwana was the second song they sang that night. The song consists of 16 lines which are arranged into 6 stanzas (see also Senft 2010a: 32f.). Pilugwana is the name of a canoe; however, this is just mentioned in passing. This song describes the erotic affairs of the baloma and the important role love magic and sweet smelling herbs and flowers play for getting engaged in these love affairs.

The first stanza depicts a scene where a group of female baloma takes a walk together with Bwiyariga; all the girls have their herbs with their love magic in their armbands - there is humming to be heard - most probably the humming of a group of men strolling around as well.

Stanza 2 introduces the powerful love magic Kwe'ineoli - it causes pain and has the power to change everybody.

The third stanza presents a young man's praise of his young girl friend - for him she is a hot spice, he very much enjoys what she is doing with him and he loves her sweet smelling herbs which implies that he very much appreciates their fresh fragrance and the overall effects of the love magic she has put on these herbs.

In stanza 4 the singer praises another girl, his beloved Yaurivori. They met, exchanged words of love and wreaths of flowers - nothing more need be said here...

Stanza 5 reports that another female baloma is walking along a beach and halts near a canoe - she tells the owner of the boat to push his canoe Pilugwana out into the sea. It remains open whether she comes with him; however, given the last stanza of the song this is quite likely (there are indeed some women who participate in the Kula in real life (see Lithgow 1978)).

In this last stanza the owner of the canoe praises his new boat and is happy that he will soon lie on the outrigger platform of his canoe ... It remains unclear whether this reference is meant metaphorically.

I would like to mention here that this very poetic song strongly reminds me of erotic Japanese Haiku. 


\subsubsection{Wosi Dorai}

(1) Kase'auvata dora'i,
bakayobuna, mavaga.

(2) Kubwedudugu unata! Tapu nukwesa, vivina! Biteorigu vagana.

(3) Bakasirasi vaponu, bakavamapusi vana, bakavagonusi buita.

(4) Kauyado'u gukwauya. M'manera doveya. Ikudutana, yamagu ikuduvira guana. Bipunuvira kasana.

(5) Dubiaruva - dabema, ebwekasema unata. Ivadunuma va keda varirorora vagana.

(6) Ma’orina, vivina, bane'i keda Bweyova. Ikatudo'u vagana.

(7) O libulibu kabagu navageyemi Bweyova.

(8) Kaila:

Kwivosegu vaponu.

\section{Song of the canoe Dorai}

We are the crew of the canoe Dorai, we push it into the sea, it's our canoe.

Come to me, men! I want her, the girl! She will take me on the beach.

We ride the wave to the sand, we exchange herbs, we pick the wreath of flowers.

I shout for my bag. Your herbs grow at the clearing. It binds them, my hand it binds and winds the herbs. She does it, turns round and goes.

Dubiaruva - the skirt, she meets a man.

They stand together on the path we enjoy ourselves on the beach. ${ }^{44}$

I'm sniffing for her, for this girl, I'm looking for her on the way to Boyowa. She calls for me on the beach.

In the bush there is my bed they will find us there in Boyowa.

You make love to me between waves and sand.

I tape-recorded stanzas of this song cycle in 1982 and ordered them into the sequence in which they are presented above (see: http://www.mpi.nl/people/senft-

44. Scoditti (1996:126ff) also presents a song which is called Dorai. However, with the exception of one stanza this song is different from the Wosi Dorai presented here. Stanza (5) of the Wosi Dorai of Tauwema is transcribed and translated by Scoditti (1996:128) as follows:

Dobi yaruwa dabe'gu The silent sightless skirts of women, my thoughts yobwekasema unata take their place, man of many loves, processing re vadudu'gu wa keda wa rirorida waga'na. along the silent path moving urged by music towards the festive canoe.

For reasons provided in Senft (1993) I do not wish to discuss Scoditti's transcript and translation here. 
gunter/research - Usi Vekota \& Usi Veponu \& Wosi Dorai/Usi Vetoi \& Usi Veponu \& Wosi Dorai/Wosi Dorai \& Usi Veponu). The Wosi Dorai consists of 23 lines which are arranged into 8 stanzas (including one kaila). Dorai is the name of another big masawa canoe, but again this cycle does not deal with the Kula trade, but with wooing, seduction and love affairs in Tuma (see 2.3 above).

The first stanza sets the scene - a group of men, the crew of the canoe Dorai, push their boat into the sea and sail away - it is unclear whether they start for a Kula expedition or just sail to another village.

In stanza 2 they have arrived at their destination. A woman welcomes them and invites the crew members to come to her. One of the men immediately is charmed by her and wants to make love with her. Being absolutely convinced that her friendly invitation indicated that she would not be unfavourably disposed to this idea he already anticipates how she will take him on the spot, right on the beach.

Stanza 3 poetically describes how a canoe uses the waves to glide into the white sand of a beach, how men and women exchange their herbs and how the men pick the girls' wreaths of flowers. These atmospheric verses can be read as similes which invite romantic and moody interpretation.

In the next stanza another scene is depicted. A man, probably another member of the crew of the canoe Dorai, shouts for his bag - he probably wants to get the betelnuts he had prepared with love magic to offer them to a woman. He notices that the herbs of the girl he addresses grow at the clearing close to the bush. The girl tells him what she does with these herbs - she binds and winds them into wreaths - and she shows him how she does this; then she leaves him teasingly at the beach.

Stanza 5 introduces Dubiaruva - a girl with the nickname "the skirt". This nickname alludes to the fact that she does not only wear beautiful and nicely coloured grass skirts which enhance her natural beauty but that she also knows how to sway her hips while she is walking so that the fibers of the skirt gently rock to the rhythm of her movements. This girl meets another man of the Dorai crew on a path and there they chat together for a while. In the last line the man tells us that they are enjoying themselves on the beach.

In stanza 6 another crew member sniffs for the fragrant smells of his sweetheart's herbs. He is expecting her to be on the way to Boyowa (that is Kiriwina Island), but then he happily hears her calling for him at the beach nearby.

In the last but one stanza a man speaks of his bed in the bush - he and his crew members who will sleep there are convinced that the girls of Boyowa will know how to find them there.

The final stanza, the kaila (a kind of refrain), summarizes the topic of the song: making love between waves and sand. 


\subsubsection{Usi Veponu}
(1) Bakavapenasi kabobu - bakareponusi gubuva.

(2) Yogana'uga bagonu boboveta kunugu.

Dubamya dabegu! Bakauvenu vivina!

(3) Bweruva'i-bagonu bwekamya kunugu bwetamya Bweyova.

(4) Nayaeva nekasa, nagabuma vana перопи.

(5) Inemi Ro'utu, kwekwanisa dabegu kagu veori nevabwadi.

(6) Kadu'etana nubegu, bitavamya tuagu. Yamtumtu. Govana!
Soon we will go to the other place we will adorn ourselves with wreaths of betelnuts.

The blossoms of the tree - I will pick them smelling of tree-blossoms - my hair.

So beautiful is my skirt!

Let's challenge them, girls!

Flowers - I pick them they are beautiful in my hair wreaths of flowers from Boyowa.

I order the flowers in my wreath, I simmer the sweet smelling herbs they are boiling.

One is living in Ro'utu, one is holding my skirt I will court another one nobody can see it.

Kaduetana my friend, he is in front of the point, my brother. Herbs - rubbed, smelling sweet - I put them in my bracelet. Let me smell!

I tape-recorded stanzas of this song cycle in 1982 and ordered them into the sequence in which they are presented above (see: http://www.mpi.nl/people/ senft-gunter/research - Usi Vekota \& Usi Veponu \& Wosi Dorai/Usi Veponu \& O Punatina \& Usi Vetoi/Usi Vetoi \& Usi Veponu \& Wosi Dorai/Wosi Dorai \& Usi Veponu). The first three stanzas of this song are also documented in the film (E 3129) by Irenäus Eibl-Eibesfeldt (see Eibl-Eibesfeldt \& Senft 1991:8ff). The Wosi Veponu consists of 19 lines which are arranged into 6 stanzas. My consultants could not provide any information about the name of this song.

In the first stanza a female baloma informs us that she and her girlfriends prepare for a katayausi, an expedition of amorous adventure (see 2.3 above). They will adorn themselves with betelnuts. The betelnuts will be strung on two strings of fibers which are worn around the head and the right and left arm so that the fibers cross above the girls' breasts.

In stanza 2 the baloma continues the description of the girls' preparation for their expedition. Like the other women she will pick tree blossoms which she will sprinkle onto her hair and on her torso which she has anointed with coconut oil. The blossoms add an additional fragrant smell to the girls' decorated bodies. After 
having checked the fit of her nicely colored grass-skirt she calls upon her friends to start for their men-challenging expedition.

In the next stanza she praises the olfactory powers of the Kiriwina flowers: she will pick them, knowing that they will enhance her beauty once she has made a wreath of these flowers and has put it into her hair - these wreaths of Boyowan flowers and their fragrance are indeed unique. In the song documented on audio-tape the singers realize the second and third line of stanza 3 as follows:

$$
\begin{array}{ll}
\text { bwetamya kunugu } & \text { wreaths of flowers in my hair - } \\
\text { bwekamya Bweyova. } & \text { they are beautiful they from Boyowa. }
\end{array}
$$

When I transcribed the song my consultants edited this stanza as presented in the song cycle above.

Stanza 4 describes how the girl checks the fit of the flowers in her wreath while she waits for the simmering herbs to boil - she will make a special perfume out of the fluid in which she boiled these herbs, put her love magic on this perfume and then put it onto her body and on the herbs she will wear in her upper armlets.

In the next stanza she boasts that she has a lover living in Ro'utu and another one - probably in her village - who has one of her skirts as a pledge of love; however, she proudly points out that she is courting yet another man - and that none of these men is aware of his rivals.

In the last stanza she introduces this man, his name is Kaduetana. He is standing at one of the points of Tuma Island. She teasingly refers to him as my brother, but it goes without saying that the brother-sister taboo is also valid in the Tuma underworld (see 2.2 above). She checks for the last time whether she has put the right amount of her perfume with her love magic onto the herbs in her upper armlets and anticipates that Kaduetana will ask her to let him smell this perfume. By now we know what will happen with him after that... ${ }^{45}$

\subsubsection{Usi Veto’i}

(1) Bakudukudu yetegu. I will make me beautiful, sit down and wait.

Binobasigu, tau. He will poke me, the man.

Bikanuveda va moi. And sleepless we will roll on the mat.

(2) Kaila:

Bakudurara vana. I will bind the herbs.

Kwanupenigu. You refused me.

Vina bitavakesa tau. A girl enchanting a man.

Binubasigu va moi. He will pierce me on the mat.

45. Scoditti (1996: 144ff, 174ff) presents two songs which are called "Weponu", but they are different from the Usi Veponu presented here. 
(3) Nakopwega natugu.

Katootu bwepota.

Kakigonu - bwemapu.

(4) Bakam'isa usi veto'i.

Usi bwenigu Bomatu.

(5) Naibuyobu gerana -

Nevanisisa vagana.

(6) Naibuyobu vekautu.

Ka'orisa reremya.

Nakanupisa erenua

okauyana Bomatu.

(7) Geponuguyagina revabu. Ima imyegu revabu.

(8) Naibuyobu kabagu.

Omyamya basiki.

Betopena gutau!

(9) Minuponu - nokuma nokikasa boveta.

Okekagu banoma. ${ }^{46}$

(10) Kwigonusa magwa'eva, kevayana yamagu.

Bakudurara vaderoru.

Vatuvanisa tau Bomatu.

Bigunigu simnabai

bio'inenogu gutau.

(11) Bakunuyega kauya okedana Myuva.

Nerakwesa-gumwara.

(12) Kamnovesa ikasi.

Kasikwabusa vamini.

Kavadenisa Bomatu.

(13) Ominuporu, gwadi.

Boku'unisa. Tau

kanodo'u gumara!

Bakia'umgwa yamagu!

(14) Ominuporu, tugu

biokwaigu, gwadi.
I am holding my child.

We go to this stone.

We pluck the flowers - we join them.

We chose the song Veto'i.

The song is good in the north.

She cradles the child -

She goes to the beach.

She cradles her wreath of flowers.

We shake the Reremya-tree.

We collect Erenua-blossoms

in the bags of the men from the north.

It starts to blow, the Revabu-wind

It comes, it blows, the Revabu.

I cuddle myself in my bed.

Outside I am sitting - alone.

Come to me, be my man!

She's crying - come in -

she bundles herbs for her bracelets.

My voice is the voice of immortals.

He cuts off the pandanus leaf, the white one and puts it into my hand.

I bind it with fragrant herbs adorning my

bracelets

I cry and go with the man to the north.

He wakes me up with Simnabai-herbs

and changes my mind, my man.

You give me the bag

on the way to Myuva

They pass them on - my valuables

We kick up a row in Ikasi.

We stay with our friends.

We go to the north.

It is crying, the child.

She gives birth to it. Man

come, you, my man!

Help me and hold my hand.

It keeps on crying, my child,

it makes me feel tired, the child.

46. Note that "banoma" is a variant of "baloma". 
$\begin{array}{ll}\text { Bemnisa kabagu } & \text { I make my bed } \\ \text { bakunarara vagana. } & \text { and go to the beach. }\end{array}$

I tape-recorded stanzas of this song cycle in 1982 and ordered them into the sequence in which they are presented above (see: http://www.mpi.nl/people/ senft-gunter/research - Usi Veponu \& O Punatina \& Usi Vetoi/Usi Vetoi \& Usi Veponu \& Wosi Dorai/Film E 3119). Stanza 3 of this song is also documented in the film (E 3119) by Irenäus Eibl-Eibesfeldt (see Eibl-Eibesfeldt \& Senft 1991:9). The Wosi Veto'i consists of 46 lines which are arranged into 14 stanzas (including one kaila). Again, my consultants could not provide any information about the name of this song.

In the first stanza a girl, harassed by her friend, tells him to sit down and wait until she is ready adorning herself. She knows that soon he will poke her - which marks the start of a night of love in which she and her friend will passionately roll on her sleeping mat - without getting any sleep at all.

In the second stanza, the kaila, we learn that a man may refute a girl's advances - however, usually he has no chance: A determined girl will bind her herbs together, put her perfume with her love magic on them and then enchant the recalcitrant aim of her desire. The power of the love magic is so strong that sooner or later they will lie together on her sleeping mat and he will do what she wants him to do.

Stanza 3 tells a sad story: A woman and her baby have died in childbirth. The mother baloma is holding her child's baloma on her arms and they go with Topileta to the gilela va sopi stone to see and enter the Tuma underworld. Before they enter Tuma the mother will pluck flowers, make wreaths for herself and for her child; decorated like this they will enter the underworld.

The fourth stanza praises the song Veto'i as well respected and liked in "the north" - the cardinal direction term is used here once more as an euphemism for Tuma.

After the woman has entered the underworld, she cradles her child and goes with it to the beach.

Stanza 6 informs us that while the new baloma cradles her child with her wreath of flowers, the other baloma shake trees to get their sweet smelling blossoms which they collect and put into the bags belonging to either their men or their lovers. These bags are intricately woven out of coconut leaves. Again the name of the underworld is avoided and the cardinal direction term is produced instead.

In the next stanza we learn that time has passed. A new time of the year is announced by the blowing of the Revabu wind.

In stanza 8 the woman prepares to cuddle herself in her bed - she is sitting outside of her house on her veranda - all by herself. She addresses a man to come, join her and be her man for the night. 
In the next stanza we find her in her house - alone and crying. However, she hears a man knocking at her door - invites him to come in and reaches for her bundles of herbs to put them into her upper armbands - to make sure that she will enchant her visitor. It seems that the last verse of this stanza is a kind of an aside of the singer(s) of this song pointing out that the song is sung in the voice of the baloma.

Stanza 10 informs us about the fate of the woman and her lover. The man cuts a white, dried pandanus leaf for her and hands it over to her. She binds some of the smelling herbs she had put into her bracelets into the leaf. She is crying, nevertheless she goes with the man to his village in the north of Tuma. After they have slept together he wakes her up with his Simnabai herbs - and his love magic indeed changes the mind of the sad newcomer to the Tuma underworld - she accepts her fate and him as her new husband.

In stanza 11 she asks him to give her her bag with her valuables on their way to Myuva, another village of the spirits of the dead. She knows that these valuables are the symbolic ones she took with her to Tuma and that her real valuables were already distributed among her relatives living in the upper world.

In the next stanza we learn that the baloma go to Ikasi to dance there. They will stay with their friends - up in the north.

Stanza 13 tells us that a newborn child is crying in Tuma. The baloma woman gave birth to it and now calls for her husband to help her and to hold her hand showing her his tenderness.

The last stanza reports that the newborn child keeps on crying, making his mother nervous and tired. Nevertheless, as soon as possible she will make her bed and join the other baloma feasting at the beach. ${ }^{47}$

47. Preparing my review of Roberts (Senft 2001) my consultants told me that one of the songs he presents on his CD and transcribes in the CD accompanying booklet is a stanza which belongs to the Wosi Veto' $i$ cycle. Here is the stanza in my edited and corrected transcription and translation (see Senft 2001:120):

Bige $m$ a - vivina.

Bigemapu tewau:

Wi ye kawalili guvanne'e!

Roberts rather free translation reads:
Her speech - the girl.

They answer, the men:

Girl put my herbs inside your bracelets!

To the girls words/

the boy replies/

their magic made/

through the aroma/

of the flowers 


\subsubsection{O Punatina}

(1) O Punatina kutoki. Bwekagonu nadauve.

Kevaruba inami. Bwetoo'i, va keda.

(2) Tam'no'egu Odukureru Odukumya - kabagu.

(3) Ovedudu, gubuva obwegunu nayabu.

(4) Nado'uyo nado'u yasaleva, yanubesa; yamvedukue. Nado'u tau o nado'u tau: Kuma kuveya! Nokwogu. M'mana, beyoyu vana - va móe.

\section{In Punatina}

In Punatina we are singing. We call for wreaths of flowers. She cradles the mother's flower. With the child, she is going her way.

I am guided to Odukureru to the stone Odukumya - to my place.

It's an Ovedudu, my betelnut I pick it and cradle it.

He shouts, yes he shouts for the ribbons, for good ones, already he sings for the dance. He calls for the men, he calls for them: Hey come and dance! Yes I like it. Your herbs, they are tapping gently the herbs - yes there on the mat.

I tape-recorded stanzas of this song cycle in 1982 and ordered them into the sequence in which they are presented above (see: http://www.mpi.nl/people/ senft-gunter/research - Usi Veponu \& O Punatina \& Usi Vetoi). The song O Punatina consists of 14 lines which are arranged into 4 stanzas (including one kaila). Punatina is the name of a village in the Tuma underworld.

In the first stanza a group of baloma is singing in the village; they ask the spirits who are listening to their songs to bring them wreaths of flowers as a sign of their appreciation. A woman is mentioned who cradles her child; the song refers to the baby with the poetic paraphrase "the mother's flower"; she passes by, going her way.

In the second stanza this woman tells us that she is going to Odukureru, another village in Tuma, to a stone called Odukumya - her place of living.

In the third stanza a man praises the quality of his betelnut - it is an Ovedudu nut which he had picked and cradled - that is to say in and onto which he has put his love magic; he will soon offer the betelnut to a woman.

In the last stanza we hear that the man shouts for ribbons with which he wants to decorate himself; he starts to sing a song which will accompany a dance of the baloma and calls upon other men to come and start the dancing. The woman expresses her delight to watch both the man who is singing and his fellow baloma dancing to his song. In the last two lines of the stanza the man praises the woman's herbs and the way in which they are tapping in a gentle rhythm while he is with her on his mat. Obviously his magic had the intended and expected effect after the woman accepted his offer and chewed the Ovedudu nut. 


\subsubsection{Wosi Bwebwe'una Song of the village Bwebwe'una}
(1) Waga kevovau, The canoe is new, yegu Tumaveaka, I come from Tumaveaka, inagu Lobwegini. my mother is Lobwegini.
(2) Kasa’i imiga’isi, bogwa uberuru, emesi take'osi. They put a spell on the waves,
already the sea is calm,
they come and one sings. $(3)=(2)$
$(4)=(1)$

In 1989 Bwetadou, a then 38 year old man of the Lukulabuta clan, sang this song; however, I only could document stanza 2 on tape (see: http://www.mpi. $\mathrm{nl} /$ people/senft-gunter/research - Wosi Bwebwe'una \& Bwetadou's dance magic/ Film E 3130). The song consists of 6 lines which are arranged into 2 stanzas. However, to sing the song properly requires the singers to first repeat the second stanza and then end it with repeating the first stanza. Thus the full cycle consists of 12 lines arranged into 4 stanzas. Bwetadou told me that this is the song of the people who live in Bwebwe'una village in the Tuma underworld. This song is also documented in the film (E 3130) by Irenäus Eibl-Eibesfeldt (see Eibl-Eibesfeldt \& Senft 1991: 13ff).

In the first stanza a baloma praises his new canoe and tells us that he comes from Tumaveaka, a village the name of which can be glossed as "Great Tuma" (see Malinowski 1974: 170 [=1916]; see also Baldwin 1945: 215 and 1950:268). The man also mentions the name of his mother - Lobwegini; with this he emphasizes that he is a man of status belonging to a high ranking clan. Proper names are clan property - thus any Trobriand Islander hearing the given name of another Trobriander or of an islander living in the Massim area can immediately identify the clan membership of - and thus even a possible clan-relationship with - the respective individual (see Senft 2007 and 2010a: 74).

Bwetadou told me that the second stanza deals with two baloma girls who expect the return of their lovers from a canoe trip. They have done weather-magic and put a spell on the waves so that the sea is calm. The two men return safely from their trip, join their sweethearts and sing songs with them.

\subsubsection{Usi Vekota}

(1) Navaniva gana - neyoyu. Nerara buita - bagonu.

(2) Navedo'u Myuva. Kuvedo'u Bomatu. Katukwasi Yaruva.

My footsteps on the beach - she hears them. White flowers in the wreath - I pluck them.

I call the girls: Come to Myuva.

You call back, you from the north.

We call you, we Yaruva. 
I tape-recorded this song in 1982 (see: http://www.mpi.nl/people/senft-gunter/ research - Usi Vekota \& Usi Veponu \& Wosi Dorai). The song Usi Vekota consists of 5 lines which are arranged into 2 stanzas. My consultants told me that they only remembered these two stanzas of the song of which they knew that it had many more stanzas. They had no idea what the name Vekota means or refers to.

In the first stanza a man realizes that his footsteps on the beach are heard by a woman - he meets her and plucks the white flowers out of the wreath she is wearing in her hair.

In the second stanza the man calls the girls who are living in the northern villages of the Tuma underworld to come to his village Myuva. When the girls call back, he tells them who is calling them. Whether the name Yaruva is the caller's proper name or the name of the men from Myuva remains unclear - again, my consultants did not know anything about this name.

\subsubsection{Butugu}

Limatu bwekasa, livana wemapu, weboda okodeva. Ekapusi numlela kwekoya. Lovi nanogu - Budibudi. E sogu nona bukulau. Limatu vebwekwanela kutokeligu, igau bitau bitaloki. Nagumakesa.

Inagu deli wala tamaguu'ula sisu - asimwaleta: makawala noso'ila.

Yegu-yam bogi bikowegu,

tutala wala ato'ila.

Kalasia bogwa esalili, nivavila - valu idamu. Akayoyu inagu tamagu.

\section{My Song/My Renown}

The speech is good, their talking matches, they come together on the beach.

Dew falls on the mountains. It comes to my mind - Budibudi. Yes my friend, you will get the idea. The speech is exciting wait for me, then one will go and talk together. She is alone.

My mother as well as my father the reason why they are here - alone: they are like flotsam. As to me - day and night it will be on my mind, all the time wherever I go. The sun - already rising, calm and quiet - the weather is fine. I fly to mother and father.

In 1989 Bwetadou sang this song; I documented it on tape but unfortunately the tape disintegrated and thus the original data is lost. The song consists of 18 lines which make up 1 stanza. Butugu has two meanings: it either means "my personal song" (which is quite often a mocking song - see Senft 2010a: 236f.) or "my renown". It is most likely that the second meaning is the more appropriate gloss with this wosi milamala. I have reasons to assume that the protagonist of this song is a woman (see below). 
In the first 3 lines of the song the singer protagonist reports that she overhears a good conversation between a man and a woman who have come together at one of the beaches of Tuma. The next two lines poetically depict the scene of the approaching night with dew falling on the mountains - which reminds the protagonist of Budibud Island, the island most baloma will pass on their way to Tuma (see 3.3.3 above). In the following line the protagonist addresses the listener of whom she is convinced that s/he will soon understand what this song is about. Then she points out again that the speech, the conversation between the man and the woman at the beach is exciting. The protagonist asks them - using the very polite and impersonalizing dual inclusive form of the verbs "bitau" and "bitaloki" - to wait for her because she wants to talk with them. The reason for why I assume that the protagonist of this song is a female becomes clear in the next line: It is stated that a woman is alone - and it is most probably this woman who then tells us that her mother and her father - the people she saw talking to each other at the beach - are here in the Tuma underworld, alone, that is without their daughter. My interpretation of the next line is highly speculative. It seems that the parents of the protagonist had an accident at sea and their baloma just managed to reach Tuma - like flotsam. The protagonist then assures her parents that she will never forget what has happened to them. Time is passing quickly - the night is over and the sun is rising - it's a calm and quiet day and the weather is fine. The protagonist has made up her mind to soon visit her parents in Tuma - to let her baloma fly to them. It may well be that this decision and her visits to Tuma will make her a woman of renown on the Trobriand Islands.

\subsubsection{Bweyega}

(1) Valam Bweyega. Samisa natugu. Kopu'esa natugu Danina Bweyova.

(2) Gwadi naibuyobu. Gwadina ke’ori orina metagu.

(3) Bigekasa biga bigéori nabweyova.

\section{The village Bweyega}

Crying in the village Bweyega.

I go and cradle my child.

I hold it tight, my child -

Danina from Boyowa.

The child - I cradled it.

The child - it was playing sitting in front of me.

Beautiful words words of the girl from Boyowa.

I documented this song in 1982. The song Bweyaga consists of 9 lines which are arranged into 3 stanzas. Bweyaga is the name of a village in the Tuma underworld. In this song a mother bewails the death of her child. Even the baloma in Bweyega cry for it. The mother wants to go and cradle her child and hold it tight for the last time - then she addresses a certain Danina from Boyowa. This may be the name of the deceased child. However, it may also be that this is the full name of 
a famous midwife from Kiriwina whose skills are praised in a string figure game called "Dania" (see Senft and Senft: 1986: 167ff; Senft 2010a: 239). It is very usual on the Trobriands to shorten proper names (see Senft 1986:131). If Danina and Dania are one and the same person, then it is most likely that this famous midwife helped the mother while she was giving birth to her daughter. This may indicate that giving birth to the child was already a difficult delivery.

In the second stanza the mother remembers cradling her daughter and watching her sitting playing in front of her.

The last stanza states that the mother has heard beautiful words - she may have had a vision in a dream of her girl's baloma visiting and talking to her. Although she knows that the child is now living in Bweyaga in the Tuma underworld she will always remain for her a girl from Boyowa - from Kiriwina Island.

\subsubsection{Wosi Dubeyara}

(1) Ka'yubusa dubemesa, inemesa Dubeyare.

(2) Baveram ugweponu etadou, nigutai bagimya, obiyega.

(3) Minuponu okwadeva minuyoya o Bweyova.

(4) Neiga'ega okunudo'u nokwanisa magubwekata.

(5) Kuveyuma nitugwa'i kauyanebu, yuvegwa'i. Kasideni bwetamya.

(6) Odenisi-vivina'i bagonuma niputana.

(7) Bunuvana, kagu vanakasavenu punuponu naibuyobu kagu kauya.

(8) Kapisina inegwa'i. Bimyegu bigitemya.
Song of the village Dubeyara

We prepare our grass-skirts, we, the girls from Dubeyara.

I will cry for the Ugweponu-canoe she shouts, my sister I pull you, she will come back.

Crying at the beach, crying and walking on Bweyova.

Movement above us put the feathers in her hair.

Come back my child, my basket, take it.

We sit down with wreaths of flowers.

Walking in line - girls -

I will pick two wreaths of flowers.

Smell of the herbs, my sweet-smelling herbs in different lines we walk I sway my basket.

She is mourning the mother.

She taught me to talk properly.

This is another one of the songs my male consultants Bulasa, Bwetadou, Mobiliuya, Mokeilobu and my female consultant Bomsamwala sang in my house on June 13th, 1997, a few days after Mwasei had died. Again they claimed that they were singing the stanzas in the order in which they were originally composed. I video-recorded this performance during which the singers sang the first 7 stanzas (see: http:// www.mpi.nl/people/senft-gunter/research - Wosi Verai \& Wosi Dubeoli \& Wosi Dubeyara). In 1982 I tape-recorded one stanza of a song called "Dubweyara" 
(unfortunately, the tape with this stanza disintegrated). I am almost sure that the names "Dubeyara" and "Dubweyara" refer to one and the same village in the Tuma underworld. Therefore I add this stanza to the 7 stanzas which I documented on video. Thus, this song consists of 19 lines which are arranged into 8 stanzas. This song was composed in Kaduwaga, the neighbouring village of Tauwema on Kaile'una Island in the 1960s on the occasion of the death of Dakayavasi, the sister of Chief Katubai (who is also called Tokumakesa; see Montague 1974). Katubai died in 2008.

In the first stanza the girls of Dubeyara prepare their grass-skirts - it is unclear whether they just prepare themselves for a dance or for a festive grass-skirt distribution - a "lisaladabu sagali" (see Weiner 1976:62).

The singer will cry for the Ugweponu canoe - most likely the name of the canoe the baloma of the deceased women will take to paddle to Tuma. The baloma of the singer's dead sister shouts - the singer tries to pull her back, knowing that she wants to come back - and she definitely will come back for the next milamala festival in Kaduwaga.

The third stanza reports that everybody on Bweyova is crying at the beach of Kaduwaga - the variant of the term Boyowa is here extended to cover all of the Trobriand Islands (and not only Kiriwina Island).

In the fourth stanza some movement in the sky is noticed - this reminds the mourners to put "Umakata" feathers for the dead in Dakayavasi's hair.

In the next stanza the mother of the deceased woman asks her dead child to come back and she offers her child her basket with her personal valuables in it if they could sit down together again both decorated with wreaths of flowers feasting, not mourning.

Stanza 6 describes girls walking in line - probably preparing for a dance or on their way to visit young men in another village - the singer will pick two wreaths of flowers, one for herself and one for the baloma of her daughter.

Stanza 7 mentions the sweet smelling herbs the girls have put into their upper armbands - the singer knows that she and her daughter now walk in different lines - it may well be that the last line is sung by the baloma of the deceased comforting her mother telling her that she will soon follow the customs of the baloma in Tuma, swaying her basket being on a katayausi expedition.

Stanza 8 makes this assumption plausible - here the baloma speaks about her mourning mother and praises her for teaching her not only how to speak Kilivila, but also how to speak it properly.

\subsubsection{Wosi Dubéoli}

(1) Bwavenu - rubegana inagu namwemya.
Bad language - my belongings my mother's custom. 
(2) Kauya bagidou kweguya sipunudou kugisi ovemwana kugabi mwaniveaka.

(3) Migim kaduvegana, $i k u d u$, ikudumapu.

(4) Bakivi - bwekivisi bigeda kagu vana puyumi namrogau.

(5) Adoki inegwei. Tabugu kapisina bakipu kevaram sigwaya okoveponu.

(6) Gugwadi okomagana, kumesi, baitusiga.

(7) Kaila:

Gudisi Yanupena, gudisi Okibobau, abani gudiverara, ayosi, ivaram.

(8) Gugwadi okomagana kumesi, baitusiga.

(9) Kasiki Dube’oli, kamya kauvalam.

(10) Kaila:

Bwadagu, bakavamvana, My brother, we play, kakivi mapoponu, kasili kauvaram kabama - Dube'oli kamya kauvalam.

(11) Kasiki Dube'oli, kamya kauvalam.

(12) Tabugu bikatugonu, kumeya. Bitano'igu bunonu nakesaba...

(13) Kaila:

Bunonu naveyami, buva, guyau bikatugonu.

(14) Kabogu bikatugonu, kumeya. Bitano'igu
The basket with the nice necklace the chiefs' talking and shouting watch the play carry the big mwali - shell.

Your face Kaduvegana, she ties sweet smelling herbs, she ties them again.

I will part them - opening up they will bite my sweet smelling herbs smell of the girl from Gava.

I think of the girl.

My uncle's sorrow -

I will break out in tears and cry my relatives are on the playground.

The children are playing, come, I will see.

The children of Yanupena, the children of Okibobau, I find a new child, I hold it, it is crying.

The children are playing, come, I will see.

We sit and sing the Dubeoli song, we start crying.

we share our betelnuts and our tobacco, we sit and cry at our place - Dubéoli song we start crying.

We sit and sing the Dubeoli song, we start crying.

My uncle will pack a parcel you bring it. I will say good-bye thinking of playing...

Thinking of the preparations, betelnuts, the chief will pack a parcel.

My uncle will pack a parcel, you bring it. I will say good-bye 
bunonu nakesaba... thinking of playing ...

Tabugu bikatugonu. My uncle will pack a parcel.

(15) Basuya yaburesi kegana namirumeru I will string Buresi-flowers bimya nagudiyoi.

(16) Kauya-kauyadou nunuva o Bweyova.

(17) Kauya, bisivinigu guyau Déulioli the voice of a young girl she will be on his mind, the girl.

The basket - its fame echoes in Bweyova. The basket, it will make me turn the chief's basket De'ulioli.

(18) Kaila:

Guyau Déulioli, kauya nokugabisa. Guyau nevadunusa Bewaga Déulioli.

(19) Kauya, bisivinigu guyau Déulioli.

The chief's basket De'ulioli, the basket you carry on your head. The chief who is walking with the people (To)Bewaga's De'ulioli

The basket, it will make me turn the chief's basket De'ulioli.

This is the second song that my male consultants Bulasa, Bwetadou, Mobiliuya, Mokeilobu and my female consultant Bomsamwala sang in my house on June 13th, 1997, a few days after Mwasei had died. Again they claimed that they were singing the stanzas in the order in which they were originally composed. I videorecorded this performance, too (see: http://www.mpi.nl/people/senft-gunter/ research - Wosi Verai \& Wosi Dubeoli \& Wosi Dubeyara). The Wosi Dubeoli consists of 54 lines which are arranged into 19 stanzas (including four kaila). My consultants did not know what the term Dube'oli means.

This song is sung by a female baloma. The first stanza is very elliptic again. It seems to hint at a quarrel about the belongings of the baloma after her death. The reference to her mother's custom may point out that she left everything in good order.

The second stanza refers to a Kula transaction between chiefs - the trade is referred to as "the play", and a nice necklace is exchanged for a big mwali shell.

Stanza 3 mentions a girl called Kaduvegana. She may be the baloma's daughter whom she left behind (see stanza 7). Kaduvegana ties fragrant herbs together.

Stanza 4 hints to the fact that her baloma mother had probably presented her daughter with love magic - as many mothers on the Trobriands do - so she still is somehow helping her daughter when she opens the herbs to put the magical spell on them. This spell will bite, that is it will help the girl seducing a desired young man. The last line tells us that the baloma came from Gava Island - there she learned how to come up with this smell of the herbs.

In the next stanza the baloma mother confesses that she still thinks of her daughter and of her uncle's sorrow when she had died. Thus it seems that 
there is no magic for female baloma that makes them forget their beloved ones immediately after they have entered the Tuma underworld. This baloma knows that whenever she thinks of her beloved ones, she will cry - and the fact that she sees some baloma who are her relatives at the playground of her village does not help her very much.

However, in stanza 6 she sees the children of the baloma playing in the middle of the village - watching them play comforts her somehow.

The next stanza reports that the children she watches play come from the villages Yanupena and Okibobau. These are two other villages in the Tuma underworld. She comforts herself that she will also find a new child - whether this means that she will have a new child of her own or whether she will adopt one, remains unclear here. She already imagines herself holding a crying child in her arms.

Stanza 8 repeats stanza 6 . The next stanza is a kind of self-reference within the song cycle performed: Female baloma sit together singing the sad Dubeoli song, and its tristesse makes them all cry.

Stanza 10 gives a kind of summary of the female baloma's daily routines. They play - and here we have probably the only allusion to the sexual activities of the baloma that play such an important role in many other song cycles documented here - they share betelnuts and chew them and they share and smoke their tobacco. However, they also sit together and cry, especially when they sing the Dubeoli song.

Stanza 11 repeats stanza 9, reporting again that female baloma sit together; they sing the sad Dubeoli song which makes them cry.

In the next stanza the baloma is convinced that her uncle will soon pack a parcel for her - most probably a parcel with all her valuables like grass skirts, body decorations, pots etc. And a visitor going to Tuma in trance will bring it - this visitor is personally addressed, but remains unknown. Receiving this basket will help her to bid her relatives a final farewell and start to enjoy the life of a baloma with all its playing around...

Stanza 13 elaborates on this topic. The baloma thinks of the preparations for packing this parcel - and the chief of her village, her uncle and thus a relative belonging to the same clan as the baloma - will not only pack this parcel himself, but also put many betelnuts in it. Formerly chiefs were the only owners of coconut and betelpalms in the Trobriand villages.

The next stanza repeats stanza 12 . Stanza 15 foreshadows already what the sad female baloma will do as soon as she will have received this parcel: She will start to make wreaths of Buresi-flowers - this is a subtle hint that she will then prepare herself to get engaged into love affairs again, forgetting all her sorrow. She is sure that she will soon charm a male baloma. 
Stanza 16 praises the basket that she soon expects to have in her hands. This basket full of her belongings and of additional presents by her uncle is already well known in Bweyova, that is on Kiriwina Island. This statement refers probably back to the "customs" of the baloma's mother mentioned in the first stanza she obviously presented her daughter with a lot of valuables which she had also inherited from her mother and other female ancestors.

In the next stanza the baloma points out again that once she has this basket she will be able to fully integrate herself into the life of the baloma in their Tuma underworld - and she mentions the name of the chief's basket for the first time: Déulioli. This basket was also called Taulioli and my consultants told me that because of its contents it once was indeed famous on the Trobriand Islands.

Stanza 18 mentions the chief's basket again, addresses the person who will soon visit her to carry it carefully on her head. The last two lines praise her uncle, Chief Tobewaga, the chief of Kaduwaga on Kaile'una Island, the predecessor of Tokumakesa (who was also called Katubai and died in 2008) as a chief who walks with the people and his basket De'ulioli (or Dubeoli ?), which will soon be in the hands of the baloma singing this song.

\subsubsection{Wosi Yéula}

Ye’ula Kwekuyuva - Ye’ula - Kwekuyuva -

busibusi mo’aga. Ocean - your canoe.

This is the only stanza my consultant Weyei could remember belonging to a song cycle that was sung while men danced holding their kedobu dance shields in their hands (see Malinowski 1922: plates XIII \& XIV). I documented this stanza in 1983. Weyei pointed out that this song was only sung in Bwetalu village on Kiriwina Island. Malinowski (1932:101) claimed that the people living in this village "probably represent the oldest layer of indigenous culture" on the Trobriand Islands.

The following songs represent cycles that were composed by Trobriand Islanders to inform the baloma of their deceased relatives about important events in their or their living relatives' lives.

\subsubsection{Wosi Oluvekoya}

(1) Kwagimesa gwadi yorana baiyore.

(2) Imireri todada imipaya - bomwe nuana-panoli.

(3) Kwatubirigu reyava neso'u - o bwanita -

\section{Oluvekoya Song}

Work child -

feeling sick, unhappy.

The rail at the side -

it fires - boom -

a hole - a reef chimney.

The wind blows away the reyava-wood the sail down - floating in the sea - 
rubakavenu va'ogu.

Damna miraveta.

(4) Nauvaruba - gugwauyabiyoiyoi - nuvagu - bwadagu.

(5) Kaila:

Bimyabegu vivina.

Bidoseligu bwelima.

Nakipu mitinegigu bwadagu.

(6) Bukuredisa tevau!

Guniseragi - Bomana nakipwagogu, temagu okeyorana gunuvenu.

(7) Nakipwagogu, temagu okeyorana gunuvenu.

(8) Mikabena tubovau berum tau va keda veimanesa miguyau, iboda mwau, yokusa overu.

(9) Neyavai nenogu:

gwadi nama

bakine. A nerakwem waga simlana masiki.

(10) Banamara ugweveaka banasoba ginigini.

(11) Maunem nuvanakumnebesa vemenu.

(12) Semesa bigenena na'iya basi nuagu, bakina.

(13) Igineda, yevata patina silubiribinegu. Biyoyounuagu natugu.

(14) Mkwewem koya, koyana kagabu kasiuna kamaduku, mwaduku kaveram.

(15) Sopi biulete mwaduku sivenu.

(16) Semesa bigenegu ginesa gunemwana. it makes me sad.

Small waves in the open sea.

A token of memory - my basket -

he will remember - my mind - my brother.

It will catch my mind, the girl.

It will drift me away the South-Easterly

It will drop my tear for my brother.

Get ready men! problems - Bomana-jail he is weeping a lot, my father Kanumayola in my village.

He is weeping barrels, my father Kanumayola in my village.

Your fighting young men a man is sitting on the road bring back your chief, he will have a problem, you all walk menacingly to the village.

The wish deep in my mind: (for) the child I come I will see it. Ah, it ran aground the canoe at the island and I live.

The painting of the big canoe the painting of many lines.

The bird's mind you tamed it in my village.

News he will bring and his anger inside, I will see it. Igineda-wind, Yavata-wind a flotilla approaches me. I feel sad for my son.

This mountain, - the Kagabu - mountain sitting together and talking, talking and crying.

Biulete-well talking in their village.

The news will come you see my husband. 
Birubi nuagu, mwadaga bairam.

Magukum - kugane kanubena - gurata kuvayasma rabe taunam mavenu.
It will calm down my heart, if only I could cry.

My breadfruit - buy it friendship - young men come out people from our village.

I tape-recorded this song cycle in 1997 after the death watch for Mwasei (see: http:// www.mpi.nl/people/senft-gunter/research - Wosi Bweyava \& Wosi Oluvekoya). The singers - Bulasa, Bwetadou, Mobiliuya, Mokivola (males), Kalivabu and Kapatu (females) - sang the song ordering the stanzas in the way in which they were originally composed. The Wosi Oluvekoya consists of 51 lines which are arranged into 17 stanzas. Oluvekoya is the name of the area around the Tuyabwau fresh water well in the south-west of Tauwema village on Kaile'una Island (see Senft 2008b: 349, Figure 5). It is obvious that this song shares the name with the Wosi Oruvekoya (see 3.3.3 above) - however, as I said at the end of the previous subsection, this song here is one of the songs that were composed by Trobriand Islanders to inform the baloma, especially those of their deceased relatives about important events in their or their living relatives' lives.

It seems that a woman is the composer and singer of this song (see stanza 16). My consultants told me that the composer was an inhabitant of Kaduwaga and that the incidents mentioned in the Wosi Oluvekoya happened in 1967. The song informs the baloma about an incident with a marine vessel, a shipwreck, a fight and a man who is imprisoned in Port Moresby, the capital city of Papua New Guinea. The respective stories are told in a rather intertwined way.

In the first stanza we hear that a young man - who is addressed here as "child" - has to work; he is sick and feels uneasy. We will learn more about him in stanza 6.

Stanza 2 reports about a marine vessel passing the Trobriands. It obviously fired one of its cannons - and the Trobrianders were quite surprised to find out that the shot made a deep hole into one of the reefs surrounding the islands - a reef chimney is a hole in a reef through which one can see the sea below it.

In the next stanza the composer starts informing the baloma about a shipwreck: Parts of a canoe are drifting on the sea - reveya is the name of a tree the wood of which is used for building a canoe - and the canoe's sail is also floating in the ocean the waves of which now are calm again. Remembering the sight of the remains of the shipwrecked boat makes the singer sad.

Stanza 4 indicates that the singer's brother has died - she will send him her basket as a token of memory with one of the people who are known to visit the baloma in Tuma from time to time - and she is sure that her brother will remember her and realize that he will be always on her mind. 
Stanza 5, the kaila, was not sung by my consultants - while I transcribed their songs they realized that they forgot it, told me the lines and insisted that it should follow the fourth stanza. In the typical style of the wosi milamala the stanza alludes to the fact that the singer's dead brother will find a girl in the Tuma underworld. The Bwalimila, the South-Easterly wind, will make the singer drift away from her bewailed brother and she will cry for him.

The next stanza brings us back to the young man mentioned in the first lines of this song. Someone is shouting commands and another one has problems - the scene sketched in a very elliptic way takes place in Bomana, the central jail in Papua New Guinea near Port Moresby. The young man knows that back home in his village, that is in Kaduwaga on Kaile' una Island, his father Kanumayola is weeping barrels because - as my consultants told me - his now imprisoned son killed a man from the neighboring village Koma.

The next stanza repeats the last two lines of stanza 6, thus emphasizing the sadness of Kanumayola.

Stanza 8 reports that the young men of Kaduwaga prepare for a fight with the men of Koma; already they are on their way to this village which will soon have a big problem. Whether this fight is connected with the murder reported in the previous stanzas remains unclear. It seems that a man sitting on the way to Koma tries to stop the fighters proposing that the chiefs of the two villages should meet and try to settle the problems without fighting. My consultants told me that this man could not stop the fighters: indeed, there was a fight between the two villages in 1967. People could no longer remember, however, how many men died and how many houses were burned in Koma. Usually such fights come to an end when a few people are killed. Then the chiefs - usually with the help of one or more intermediates - reinstall peace and organize big food distributions, during which persons whose houses were destroyed or whose relatives were killed get a kind of compensation for their losses in the form of food, betelnuts, grass skirts and pigs.

Stanza 9 leads us back to the shipwreck. The singer wishes to see the young man again who drowned. The canoe ran aground near Bulivada Island - and the singer was obviously the only one who survived this accident.

The next stanza praises the beauty of the masawa canoe which was painted in the traditional colors black, white and red.

Stanza 11 talks about the mind of a bird which was tamed in Kaduwaga these two lines remain completely cryptic for me (as well as for my consultants).

It seems that stanza 12 refers back to the fight between the two villages on Kaile'una Island - somebody will get very angry about some news he will receive. Again, the meaning of these two lines is absolutely unclear to me. 
Stanza 13 talks about a Kula expedition visiting Kaduwaga - in former times Kaduwaga had excellent Kula connections with villages on Dobu Island. However, seeing the splendid sight of masawa canoes under full sail reminds her of her son and she feels sad. It may be that her son either was one of the persons who died after the shipwreck close to Bulivada or that he is the young man imprisoned in the Bomana jail. Again, this remains unclear.

Stanza 14 reminds the listener to (and reader of) the song of other milamala songs which refer to crying for, as well as mourning and talking about, beloved relatives who have recently died. Like some lines of other milamala songs presented above do, a mountain is mentioned here as well together with the bewailing of dead people (see subsections 2.3.1-2.3.3 \& 2.3.12).

Stanza 15 mentions a well and people who are talking in their village - neither my consultants nor I could find any meaning in these two highly elliptic lines.

The next stanza refers to news again that will reach the singer - then her husband will see that this news will make her heart calm down, although she still wants to cry. For this and for the last stanza I can only offer a rather wild speculation: If one of my readings of stanza 13 is right and the singer of this song is the mother of the imprisoned young man, it may well be that she expects to hear that her son will soon be released from prison. Stanza 14 could then be read as depicting the scene where young Trobrianders offer the man from Kaduwaga a breadfruit and their friendly support waiting for him on his way out of prison; they also tell him that other people from Kaduwaga have come with them to welcome him and to safely bring him back home to his village. However, all this must remain speculation - my consultants told me that such an interpretation is possible and that it even sounds plausible, however, at the same time they also told me that they had no idea whether my proposed interpretations for the songs of the Wosi Oluvekoya were the right ones.

3.3.19 Wosi Opesi / Wosi Diyapani

(1) Opesi siopu tonena keda'usi kedana, matoki.

(2) Siliunanu kwatuvego aoelumgwa ba'utu.

(3) Vatutanokopu kanono vatutana benayo.

(4) Mipoleni diyapani kasa-kanubena!
The Office Song /

The Song of the Japanese

The Office at the wharf a man living on the road to the banana-orchard on the road, there he is standing.

Their picking of the fruits I think I break (the branches).

Time is flying -

it's time to rest.

You stand in line in the Japanese row - friendship! 
Mipaia bom - bekenu tau.

Bimya, rivenena: Deli!

Tamapu mavenu.

(5) Igini mapwepu:

Gabena kwatupelisa doketa!

Temnabegu temagu, makekarogu, bwadagu, bakasirara sipeleni.

(6) Misebutu inayo bavayoge yoganga bwabwato.

(7) Koyekoye masiki gara'uni. Ribuna vanuvana Ribugava nalibu mavenu

(8) Kaila:

Koyekoye tanegasi masiko gara'una taramwani, neribu vakidosi ospetela. Vaya gunuvenu namteyou kwero saliu karasia. Suviri, gavana, bakinamvenu!
Their firing - boom - the falling of a man. Rumours, news: Jail!

Our talking in the village.

He writes in our paper:

Governor transfer the doctor!

It convinced me my father, we two are together, my brother, we will fly on their plane.

I tell all mothers

I will make it bad, it's not good.

In the mountains I stay for no reason.

Deep in my mind I think of

Ribugava mourning in her village.

In the Tanegasi mountains

I stay for no reason without anything, and she is mourning she feels sick as if she was in hospital. The river at my village the rising of the sun the setting of the sun. Show me the way, governor, I want to see your village!

This is another song which I tape-recorded in 1997 after the death watch for Mwasei (see: http://www.mpi.nl/people/senft-gunter/research - Wosi Opesi \& Wosi Oruvekoya \& Wosi Diyapani) The singers - Bulasa, Bwetadou, Mobiliuya, Mokivola (males), Kalivabu and Kapatu (females) - sang the song ordering the stanzas in the way in which they were originally composed. The song consists of 31 lines which are arranged into 8 stanzas (including 1 kaila). My consultants told me that this song refers to another fight between the people of Koma and Kaduwaga and about a woman from Gawa whose boyfriend was a Japanese soldier in World War II. The song has two names: Wosi Opesi refers to the office of the Australian Assistant Resident Magistrate (ARM) of the Losuia district; the ARM was based in Losuia on Kiriwina Island, and Wosi Diyapani refers to a Japanese soldier who had a girlfriend in Gawa. My consultants also told me that the people of Kaduwaga boasted before their fight with the people of Koma that they are as strong as the Japanese soldiers who fought in Milne Bay during World War II. The song informs the baloma about the ARM's office and his deeds in Losuia, about the fight between Koma and Kaduwaga and about the Japanese soldier and his Gawan girlfriend. 
The first stanza refers to the ARM's office at the wharf in Losuia and probably to the Magistrate himself as the man standing on the road to the banana-orchard.

In the next stanza we hear that people are busy picking greens and fruits in the gardens - it may well be that these workers are Trobrianders that were imprisoned by the ARM because they did not follow the colonial officer's rules. They had to work for a few days for the ARM's station and then were released and went back home to their villages (see Connelly 2007).

Obviously the work is not too hard - as stanza 3 indicates. Time is flying and the workers have deserved a rest.

This rather peaceful scene in Losuia stands in sharp contrast to the contents of stanza 4. The people of Kaduwaga and the people of Koma face each other, standing in lines ready to fight. Somebody tries to prevent them from starting their warfare - however, his plea for friendship is unsuccessful - the parties do not fight in the traditional way - a rifle is shot, a man is fatally hit and falls down on the ground. Rumours about this accident reach the ARM's ears, the colonial officer sends a patrol to Kaile'una and a man is taken and put into jail. This is something which is talked about in every village on Kaile'una Island.

The next stanza brings us back into the colonial realm. The Australian politicians decided in 1942 to evacuate "all white government officials, missionaries and traders" (Connelly 2007:17). Ever since the days of Dr. R. L. Bellamy who arrived in 1904 as the first ARM in Losuia the ARM was also the head of the hospital there. This explains why the second line of this stanza refers to the ARM as "the doctor". The ARM accepts the order of the Governor. It seems that the Trobriander who is accused of murder has to fly with the ARM together with another prisoner; it seems highly unlikely that the ARM addresses one of his prisoners or is addressed by the latter as "brother".

Stanza 6 provides the hot-blooded fighter's insight that he has done something bad; he will tell all mothers to admonish their adolescent boys not to act in a fight like he did.

In stanza 7 a completely new story is told. A Japanese soldier who had a girlfriend in Gawa is imprisoned in a jail on Gawa Island. He is convinced that he has not done anything wrong yet and is imprisoned for no reason - obviously the composer of this song rather naively underestimated what it meant to be a prisoner of war. The young Japanese soldier thinks of his girlfriend Ribugava who is mourning for him in her village nearby.

The following kaila takes up this topic and repeats the first two lines of stanza 7. However, we also learn that the prison is in the Tanegasi mountains on Gawa. The girl is mourning for her Japanese lover and feels sick because of her sorrow. She looks at the peaceful river near her village, days pass but she cannot see her lover 
anymore. In the last two lines the soldier seems to ask the Governor of Papua to let him see the village of his girl. However, my reading of these lines is again rather speculative.

\begin{tabular}{|c|c|c|}
\hline 3.20 & Wosi Diyapani & The Song of the Japanese \\
\hline (1) & $\begin{array}{l}\text { M koti kokoseni, } \\
\text { bimya bigenena. } \\
\text { Batoli opisi, } \\
\text { kwevili gabemani. } \\
\text { Bayosi tovau, } \\
\text { magigu gunemwala. }\end{array}$ & $\begin{array}{l}\text { Your court case, governor, } \\
\text { they say the words. } \\
\text { I will stand in the office, } \\
\text { you change the government. } \\
\text { I will hold a new man, } \\
\text { I want my husband. }\end{array}$ \\
\hline (2) & $\begin{array}{l}\text { Guguyana iyo! } \\
\text { Guyema so- } \\
\text { livenena - bomwe- } \\
\text { nukwema so. }\end{array}$ & $\begin{array}{l}\text { Stop it girl! } \\
\text { Talk to your friend - } \\
\text { her speech - boom - } \\
\text { talk to your friend. }\end{array}$ \\
\hline
\end{tabular}

This is the last song which I tape-recorded in 1997 after the death watch for Mwasei (see: http://www.mpi.nl/people/senft-gunter/research - Wosi Opesi \& Wosi Oruvekoya \& Wosi Diyapani). The singers - Bulasa, Bwetadou, Mobiliuya, Mokivola (males), Kalivabu and Kapatu (females) - sang the song ordering the stanzas in the way in which they were originally composed. The song consists of 10 lines which are arranged into 2 stanzas.

The first stanza sets the scene in a courtyard. We deal again with the Japanese soldier and his Gawan girlfriend (see previous subsection). After the lawyers have discussed the case, they will call the local girl to the witness stand. She will stand there courageously, ask the lawyers to change the government's rules and to give her the Japanese man as her new husband.

In the second stanza the reaction of the Australians is mentioned. They ask the Gawan girl to stop her silly proposals and tell her that she can speak to the prisoner of war. The last but one line praises the girl's brave speech and her words that sounded like bullets. However, the only thing she achieves is that the lawyers allow her to talk to her Japanese lover.

This is the last wosi milamala I documented in Tauwema. I will finish this chapter with a few comments on the form and content of these songs.

\subsubsection{A few final remarks and comments on form and content}

The wosi milamala that I have documented here show a rather high degree of variation with respect to the number of their constituting songs and the way in which these lines are arranged into stanzas. This variation is documented in Table 1. 
98 The Tuma Underworld of Love

Table 1. Form and classification with respect to contents of the wosi milamala

\begin{tabular}{|c|c|c|c|c|}
\hline Sub-section & Song name & Classification & Lines & Stanzas \\
\hline \multirow[t]{2}{*}{3.3 .1} & Wosi Bweyava I & erotic & 40 & 11 \\
\hline & Wosi Bweyava II & erotic & 46 & 12 \\
\hline \multirow[t]{2}{*}{3.3 .2} & Wosi Omnuyobu I & erotic & 74 & 19 \\
\hline & Wosi Omnuyobu II & erotic & 75 & 19 \\
\hline 3.3 .3 & Wosi Oruvekoya & erotic & 42 & 11 \\
\hline 3.3 .4 & Wosi Verai & erotic & 39 & 12 \\
\hline 3.3 .5 & Wosi Onegava & erotic & 75 & 27 \\
\hline 3.3 .6 & Wosi Pilugwana & erotic & 16 & 6 \\
\hline 3.3 .7 & Wosi Dorai & erotic & 23 & 8 \\
\hline 3.3 .8 & Usi Veponu & erotic & 19 & 6 \\
\hline 3.3 .9 & Usi Veto'i & erotic & 46 & 14 \\
\hline 3.3 .10 & O Punatina & erotic & 14 & 4 \\
\hline 3.3 .11 & Wosi Bwebwe'una & erotic & 12 & 4 \\
\hline 3.3 .12 & Usi Vekota & erotic & 5 & 2 \\
\hline 3.3 .13 & Butugu & mourning / sad & 18 & 1 \\
\hline 3.3 .14 & Bweyega & mourning / sad & 9 & 3 \\
\hline 3.3 .15 & Wosi Dubeyara & mourning / sad & 19 & 8 \\
\hline 3.3 .16 & Wosi Dube' oli & mourning / sad & 54 & 19 \\
\hline 3.3 .17 & Wosi Ye’ ula & $?$ & 2 & 1 \\
\hline 3.3 .18 & Wosi Oluvekoya & informative & 51 & 17 \\
\hline 3.3 .19 & $\begin{array}{l}\text { Wosi Opesi / } \\
\text { Wosi Diyapani }\end{array}$ & informative & 31 & 8 \\
\hline 3.3 .20 & Wosi Diyapani & informative & 10 & 2 \\
\hline
\end{tabular}

The longest song is the "Wosi Onegava" (see 3.3.5) which consists of 75 lines that are arranged into 27 stanzas. The longest stanza consists of 18 lines - and a whole song, the "Butugu" (see 3.3.13) consists of just this one stanza. The second longest stanzas are both kaila stanzas and consist of 9 lines each (see stanza 9 in Wosi Oruvekoya (3.3.3) and stanza 8 in Wosi Opesi (3.3.19)). It is difficult, though, if not impossible to compare the shorter songs with the long elaborated songs, because I do not know whether I could document all the stanzas of the songs presented here. For instance, only one of my informants remembered one stanza of the Wosi Ye'ula, the only song in my collection which was sung while the men who danced to it were holding kedobu dance shields in their hands (see 3.3.17). In subsection 3.1 I already mentioned characteristic features of the melodies and 
the singing of the wosi milamala and I pointed out at the beginning of Section 3.3 that I am unable to transcribe these melodies; however, the interested reader - and probably also expert ethnomusicologists - will get an idea of these songs when they listen to the audio- and video-documents on my website.

According to their content all these songs narrate stories; the majority of these stories that are presented in the first 12 songs presented in this chapter deal with the erotic life of the baloma in their Tuma underworld. It is interesting to note that I could document two slightly different versions of the first two songs.

The next four songs describe the mourning of the bereaved and/or the baloma before they enter Tuma - and in the case of female spirits also a few days after they have entered the underworld.

I cannot say anything with respect to general contents for the two lines of the Wosi Ye'ula which were only remembered by one of my old consultants in 1983.

The last three songs provide information for the baloma about events in the lives of their relatives living on the Trobriand Islands. The fact that the most recent of these songs was composed in 1967 shows that the Trobrianders lost the faculty of composing songs in the biga baloma/biga tommwaya variety of Kilivila (see 3.1) and their active competence in this register just within the last 40 years or so. However, it also proves that Vansina (1965:43) was right when he stated that " $[t]$ he very fact that the practice of oral narrative song has endured so long is proof enough that it can absorb new ideas and construct new formulas". It is interesting to note that one of these informative songs had the same title as an erotic song the Wosi Oluvekoya/Oruvekoya - however, it is obvious that the songs have clearly different content.

Before I deal with the loss of the biga baloma and the wosi milamala just mentioned and discuss the consequences this loss will have for the culture of the Trobriand Islanders, I would like to make a brief final note on two important aspects with respect to the contents of the songs presented in this chapter.

In the wosi milamala presented we find the names of the following villages in the Tuma underworld: Bwebwe'una, Bweyaga, Myuva, Numanuma, Odukureru, Okikobau, Omnuyobu, Punatina, Ro'utu, Tasikidoveya, Tumaveaka and Yanupena. Thus, there are many more villages in the underworld than the three reported by Malinowski (1974: 159 [=1916]; see 2.3 above) and Namunu (1984: 45; see 2.1 above; see also Harwood: 1976).

There is only one erotic song, the Wosi Bwebwe'una, in which no fragrant strings or wreaths of flowers, blossoms, herbs and leaves are mentioned. Even in two of the sad songs - in the Butugu and in the Bweyega - there are explicit references to smells. This highlights the importance of the olfactory sense for the Trobriand Islanders. As Malinowski did before him, David Howes (2003: 74) rightly points out that "Massim attitudes toward smell are complex" and he discusses 
these attitudes in a whole chapter (Howes 2003:175-203) of his book "Sensual Relations". The wosi milamala proof him right when he emphasises the "power of smell in human affairs" (Howes 2003:192) on the Trobriands and especially in erotic and sexual encounters of Trobriand Islanders. We know by now that most forms of love magic - especially the most important and strongest one are put on aromatic herbs and wreaths of flowers and unfold their full power as soon as people smell their fragrance which carries the magic. Already Malinowski (1929:166) pointed out that the Trobrianders say that it is the eyes "which makes us desire to copulate ... a man with closed eyes will have no erection"; however, as Howes (2003: 195) notes, "they also hold that the nose can sometimes replace the eyes, such as 'when a woman discards her grass petticoat in the dark' and desire is aroused in her male partner just the same (Malinowski 1929: 166). According to Trobriand theory, then, olfaction is continuous, whereas vision is an intermittent motive of sexual excitation, susceptible to being interrupted by darkness". And at another place, Howes (2003:186) pointedly summarizes the importance of smell for the Trobrianders as follows: "Thus, in the Trobriands ... desire does not exist unless and until it has been evoked and directed by ... smell ... smelling leads to copulating". With a few exceptions this direct consequence of smells is not explicitly mentioned in most of the songs documented here, however, the erotic songs of the wosi milamala poetically insinuate this common knowledge. 


\section{The moribund language of the spirits of the dead and its consequences for the Trobriand Islanders' culture}

Kilivila can still be classified as a viable but relatively small language with about 28,000 speakers: it is "spoken in [a community] that [is relatively] isolated [and] with a strong internal organization, and aware of the way [its] language is a marker of identity" (Crystal 2000:20).

The Trobriand Islanders are extremely proud of their language (see Senft $2010 \mathrm{~b}$ ). This pride almost equates to arrogance (which is, of course, an absolutely positive quality from the point of view of language endangerment and language maintenance). Among other things this pride is made manifest by the fact that the Islanders do not speak Tok Pisin on the Trobriands. Government officials working in Losuia, the governmental centre of the Trobriand Islands, are expected to learn Kilivila if they come from other parts and language communities of Papua New Guinea.

Kilivila is still the mother tongue of all the children born on the Trobriands. A number of older people can also speak Motu, the old coastal lingua franca of Papua New Guinea (see Dutton 1985); however, they hardly do so and the young generation does not learn Motu any more. English is taught at the missionary and government schools on the islands and has acquired the status of the second language especially of the educated youth who use it to communicate with tourists and other Papua New Guineans.

Another issue that supports my (maybe too optimistic) classification of Kilivila as a language that is not endangered is the Trobriand Islanders' metalinguistic awareness that is documented in their extremely rich metalinguistic vocabulary (see Senft 2010a). As mentioned above (see 3.1), the speakers of Kilivila differentiate and metalinguistically label eight of what I have called "situational-intentional varieties" - that is registers of Kilivila that are used in a given special situation and produced to pursue (a) certain intention(s). One of these registers is the biga baloma/biga tomwaya variety which is constituted by the wosi milamala. In the Introduction to this volume I already mentioned that even back in 1982/83 I had difficulties to find consultants who knew the meaning of these songs and in 
Section 3.1 I report that in 1989 there were only 5 consultants in Tauwema who understood the biga baloma variety and could translate the wosi milamala. Thus, as mentioned in the previous section, this register is highly endangered and actually moribund these days. Unfortunately, the same is also true for the biga megwa variety (see 3.2). Given the importance of the biga baloma for the wosi milamala in the Trobrianders' mourning and harvest rituals and the impact of magic for the Trobriand Islanders one wonders why these varieties have become endangered and now are even moribund. In what follows I will provide an answer to this question.

In his seminal article "The Life of Myth" Malinowski (1963b: 306) emphasizes the importance of the milamala festival for teaching the young Trobriand Islanders the central ideas of Trobriand eschatology. He writes:

... during the sacred season of harvest rejoicing, the younger generation are reminded by their elders that the spirits of their ancestors are about to return from the underworld and visit the ancestral village. The dogmatic substance of Trobriand belief about the fate of the soul after death, the nature of the underworld, and the various forms of communion between the living and the dead, are stated at that season more frequently than at any other time...

Thus, during the harvest and after, at the season of Milamala, when the spirits come for a few weeks and settle again in the villages, perched upon the trees or sneaking about the houses, sitting on high platforms specially erected for them, watching the dancing and partaking of the spiritual substance of the food and wealth displayed for them, the knowledge of the whole dogmatic system concerning spirits is necessary, and it is then imparted by the elder to the younger...

In order to keep in touch with the supernatural realities and happenings of the Milamala, it is necessary for every one to be instructed in the ways of spirits and on their behaviour: how they manifest their existence and how they can be reached by the living; how they show their anger and their pleasure. On the whole, adherence to custom and tradition pleases the ancestral ghosts, while neglect angers them. The rules of conduct of man towards spirits and their reactions to them are given....

And a few pages later Malinowski (1963b: 312) points out that " $[t]$ he spirits are in general conceived of as the guardians of tradition". This tradition was also partly codified in the wosi milamala and in the myths that are necessary to understand these poetic songs - as I have shown in Chapter 2 above. Myths are cornerstones of eschatological systems. In his lecture on "Myth in primitive psychology" Malinowski (1932: 73) writes:

Studied alive, myth ... is not symbolic, but a direct expression of its subjectmatter; it is not an explanation in satisfaction of a scientific interest, but a narrative resurrection of a primeval reality, told in satisfaction of deep religious wants, 
moral cravings, social submissions, assertions, even practical requirements. Myth fulfils in primitive culture an indispensible function: it expresses, enhances, and codifies belief; it safeguards and enforces morality; it vouches for the efficiency of ritual and contains practical rules for the guidance of man. Myth is thus a vital ingredient of human civilization; it is not an idle tale, but a hard-worked active force; it is not an intellectual explanation or an artistic imagery, but a pragmatic charter of primitive faith and moral wisdom.

And on the last pages of this lecture he summarizes the importance of belief systems and myths for the explanation of nature and human culture in general (Malinowski 1932: 115ff):

Belief ... whether in magic or in religion, is closely associated with the deepest desires of man, with his fears and hopes, with his passions and sentiments. Myths of love and death, stories of the loss of immortality, of the passing of the Golden Age, and of the banishment from Paradise, myths of incest and of sorcery, play with the very elements which enter into the artistic forms of tragedy and of romantic narrative...

... once we have realized that myth serves principally to establish a sociological charter, or a retrospective moral pattern of behaviour, or the primeval supreme miracle of magic - it becomes clear that elements both of explanation and of interest in nature must be found in sacred legends.

The function of myth, briefly, is to strengthen tradition and endow it with a greater value and prestige by tracing it back to a higher, better, more supernatural reality of initial events. Myth is, therefore, an indispensable element of all culture.

Thus, the indigenous Trobriand eschatology was constituted by the belief in the baloma, their life cycle and their Tuma underworld, by the milamala songs which codify these beliefs and reiterate them whenever they are sung, by the myths that explain their religious truths, and by the magic the ancestors had passed on to them to control nature and society.

However, great change was on the horizon: as early as 1894 the Overseas Mission Department of the Methodist Church commenced work in the Trobriand Islands (see Senft 1992, 1994; 1997c). ${ }^{48}$

In 1935 Roman Catholic Missionaries (M.S.C.) from Australia began their work on the Trobriands. Up to 1988 the Roman Catholic Church was represented by two Australian priests from the Mission of the Sacred Heart (M.S.C.). Then the bishop of the Massim diocese allowed the Italian P.I.M.E. (Pontificio Instituto Missioni Estere) mission to start their work on the Trobriands, and moved the two M.S.C. missionaries to Alotau and to a small island in the Louisiade Archipelago. At present a P.I.M.E. priest from Italy is based on Kiriwina Island.

48. In what follows I heavily draw on Senft (2010b: 87-91). 
In the late seventies of the last century the church of the Seventh Day Adventists started to perform their missionary work in a few villages on the Trobriand Islands; however, so far they have only played a marginal role there.

The first Methodist missionaries had some problems with the Trobriand Islanders and vice versa. On the one hand it was difficult for members of a matrilineal society to come to terms with the central Christian relationship between God the Father and his son Jesus Christ. On the other hand, it must have been extremely difficult for the Christian missionaries to tolerate the Trobriand Islanders' understanding of morality and sexuality. In his memoirs William Bromilow (1929: 192f.), a Methodist missionary pioneer and chairman of the New Guinea district mission who stayed at Dobu Island for 17 years, points out the following:

The natives of the Trobriands presented peculiar difficulties to the missionaries. Though in many respects they were more intelligent and capable than their neighbors of other Groups, yet their entirely non-moral outlook upon their common life as men and women made them more unresponsive to the Gospel than were the wilder savages of other islands.

The Trobriand Islanders' ideas of sexual morality of the living as well as of the dead must indeed have shocked the first Christian missionaries. Nevertheless, slowly and gradually the missionaries gained more and more influence on the Trobriands, and we will soon see why.

Today, the Church encompassing most believers is the Methodist Church. All Methodist priests on the Trobriand Islands are Papua New Guineans, and every village with a Methodist church has at least one local village priest, the so-called "misinari" ${ }^{49}$ The Catholics took over this policy from the Methodists and established a network of local catechists in the villages with Catholic inhabitants; these catechists are also called misinari.

In general, the local misinari are individuals with highly motivated social upward mobility in the Trobriand society with its strictly hierarchical stratification (see Malinowski 1929, 1935; Powell 1957; Weiner 1976). They undergo training at a mission school for a few months where they learn to master English (to a certain degree), to write, and especially to read, interpret and expound the Gospels that were translated into (a slightly Dobu based variety of) Kilivila (Lawton 1997). Thus, the misinari gain prestige as specially trained lay-priests, catechists or deacons being associated with the influential mission.

As Robert Louis Stevenson had already noted in 1896, with respect to the South Seas there "is but one source of power and one ground of dignity - rank"

49. "misinari" is a Kilivila loan word - from English "missionary". 
(Stevenson 1896:282). This holds true for the Trobriand society, too. As already mentioned before, Trobriand society is highly stratified. The most important access to political power is membership in the highest ranking subclans. There were and still are some other means to acquire status within the society, such as being a versatile rhetorician, a master-carver, an expert magician, and so on. However, compared to the political significance of inherited rank, these alternatives for achieving status are of secondary importance. In former times, individuals belonging to the two lowest ranking clans of the four main Trobriand clans had little chance of gaining status or exercising any kind of political influence.

With the growing influence of the Christian churches on the Trobriands members of these two lowest ranking clans engaged themselves in these new institutions of political impact. With the increase of the churches' power, being a misinari implies being a woman or a man of rank. Most of the Trobriand misinari nowadays belong to the lower two of the four Trobriand clans. The fact that the misinari - still a relatively young group of social climbers - have achieved political influence within the villages is documented by the ritualized greeting formula that is used to start important public speeches: In this formula the misinari are addressed immediately after the chief(s).

This indicates that the misinari made it - at least with respect to official acknowledgement - to displace the magicians, traditionally the second most important representatives of social power and control - following in rank immediately after the chiefs. According to Malinowski (1926b: 93):

[magic] invariably ranges itself on the side of the powerful, wealthy and influential, sorcery remains a support of vested interest [...] in the long run, of law and order. It is always a conservative force, and it furnishes really the main source of the wholesome fear of punishment and retribution indispensable in any orderly society. There is hardly anything more pernicious, therefore, in the many European ways of interference with savage peoples, than the bitter animosity with which Missionary, Planter, and Official alike pursue the sorcerer. The rash, haphazard, unscientific application of our morals, laws, and customs to native societies, and the destruction of native law, quasi-legal machinery and instruments of power leads only to anarchy and moral atrophy and in the long run to the extinction of culture and race.

Thus, Malinowski was completely aware of the processes of culture change the missionaries had to induce in Trobriand society to achieve rank - and thus power - and he warned of the consequences of this culture change. This is also illustrated by the following quote (Malinowski 1992:46):

Thus all savage belief, myth and ritual is evil growth in the eyes of the missionary, to be weeded out and burnt. That, of course, is his business. It is all very well 
to call everything which a native beliefs 'superstition', and to try to import 'true faith' instead. But the fact is that a savage community has obtained its religion as the product through centuries of natural development, and that it suits savage mentality and their social organization perfectly well, whereas European religion cannot be grafted on to an entirely different social, mental and moral soil, and requires absolute upheaval of all the natives' own civilization before it can be introduced at all...

As Malinowski foresaw, the missionaries first and foremost fought against the magicians, their Weltanschauung, and thus against the model of culture they represented and guarded. Because the magicians were too powerful, the missionaries could not start directly to fight their rival, their 'natural enemy', the 'sorcerer', who stands for 'conservatism, the old tribal order, the old beliefs and appointment of power' (see Malinowski 1926b: 93). Therefore, they had to fight first against the standards and values the Trobriand magicians represented. Belief in magic was not denounced directly as something 'heathenistic'. Instead, the strategy pursued to fight these 'pagan' customs - according to the village priests' judgment - has been much more subtle: The local village priests and catechist, the misinari, argue that there are two ways to live one's life. One way is the old, traditional way which includes magic and the eschatological belief in the immortal spirits of the dead living in the Tuma underworld. The other way is the new Christian way of life with its specific Christian beliefs and its own eschatological ideas. Both ways are mutually exclusive, or, to say it in the local priests' words: "one can either walk on the way of the ancestors or on the Christian way together with Jesu Keriso, the Lord Jesus Christ". This strategy of the missionaries and their personal rejection of traditional eschatology is strikingly documented in the following observation reported by Father Baldwin (1950:284). One of the new local Trobriand catechists visited the Catholic mission in Gusaweta on Kiriwina Island. He overheard Father McGhee, one of Baldwin's fellow Catholic missionaries there, singing stanzas of a milamala song. He reacted to this with the indignant comment:

"Sena baloma", meaning "too necromantic". He ... could not bear that he should contaminate himself with such stuff ... all those natives more familiar with the Christian mentality were the most antipathetic towards this type of wosi...

From the very beginning of their work the misinari have been telling the Trobriand Islanders to pray for things like a good yams harvest, rain or nice weather and not to ask a magician for help. Today there are even some special public prayers for good harvests. In the last few years especially women have been accepting the missionaries' ways of Christian preaching and self-presentation, and the clear and simple alternatives - the traditional magicians with their formulae and rites on the one hand and the misinari and their prayers on the other hand - still cause 
much tension in families where the husbands of pious wives are expert magicians. Nevertheless, magicians, whether female or male, have gradually lost influence in the society these days, and accordingly the estimation of their magical skills and their knowledge of magical formulae has decreased. In 1989 I could observe that many Trobrianders thought that there is actually no need anymore to bequeath their formulae to the members of the younger generation, and in turn, the younger generation these days hardly sees any sense in learning these formulae. However, as I have pointed out above, the Trobriand Islanders' belief in the magical power of words included their conviction in magic as a means of controlling nature as well as the incidents affecting their personal lives. Once this conviction is lost a political and ritual power vacuum remains - and misinari and missionaries use this vacuum for their own means and ends. The magician's ritual and political power has been replaced by the priest's ritual and political power in Trobriand society.

Thus, the increasing influence of Christian belief and the growth of the local village priests' status and political power is responsible for the loss of the text category 'magical formula' and thus for the moribund state of the situationalintentional variety constituted by the magical formulae, the biga megwa.

However, the changes in the Trobriand Islanders' evaluation of the concepts 'magic' and 'religion' do not only affect the biga megwa. The Christian religion and its specific eschatology is also gradually replacing the indigenous Trobriand eschatology. ${ }^{50} \mathrm{I}$ have demonstrated in this volume that much of this eschatological knowledge is codified in the wosi milamala. With the religious changes induced by the missionaries and misinari these songs also lose their meaning and significance for the society. They are still sung after the death of a Trobriander and to preserve some part of the ritual aspect of the harvest festival; however since the mid 1990s the milamala period has been reduced by the local Kiriwina Community Council (in cooperation with the churches and the Milne Bay Provincial Government) to a few days only. Thus, there is simply not enough time anymore for teaching the young Trobriand Islanders the central ideas of Trobriand eschatology during the milamala harvest festival. The wosi milamala are still sung, but - as mentioned above - the vast majority of the villagers including the singers of these songs no longer understand their meaning. Many of the wosi milamala are already forgotten, and I am convinced that in a few years time the 'biga baloma' variety will have died.

50. The ideas of the life of a baloma in the Tuma underworld which are codified in the wosi milamala may help explain why this process took such a long time. Just compare the Tuma underworld with the picture of the Christian paradise sketched out quite humorously by Ludwig Thoma (1965). 
The loss of the 'biga baloma' and the 'biga megwa' varieties of Kilivila affect indigenous forms of ritual language. In general we can regard ritual language as the recognized culmination of the learning of knowledge which is basic and fundamental for the social construction of a society's reality (see Senft 2009a). This reality, in turn, fosters its stability with the help of the relative stability of ritual language. As I have outlined above, the changes that affect these language varieties are induced by cultural change. However, such language changes, once induced, have severe consequences for the organization and construction of the culture of the respective society in turn because it escalates the dynamics of change.

The misinari have finally been very successful in changing the society they infiltrated and which they have been indoctrinating for more than a century. With their increasing political influence, the misinari also have been changing moral standards of the society. In the eyes of the village priests, modern clothing is more decent - especially for women - than traditional Trobriand clothes. For a girl or a woman to appear bare-breasted and to wear the traditional grass skirt without a cotton skirt underneath and for little children to walk around naked has come to be denounced as indecent. While in 1982 the majority of the Trobriand Islanders proudly praised their traditional dress for its beauty, comfort and suitability for the tropical climate, and most parents proudly presented their children in traditional clothes, the majority now, while sweating in their garments made of synthetic fibers, praise these clothes as being more modern and more 'decent', especially according to misinari standards and criteria (see Senft 1997c: 50f.). However, at least as far as I know - my Trobriand consultants were actually rather reluctant to talk with me about these matters - the misinari have not managed yet to supersede the traditional ideas about premarital sexuality, family life and love with the respective Christian concepts.

However, the induced changes have severely affected the indigenous belief system of the Trobriand Islanders. Necessarily, these changes resulted also in new, European and Christian, biased systems of social and religious values and beliefs. And that these profound changes are also reflected in the language of the Trobriand Islanders is only natural: The processes of change influenced the language which in turn served to foster these changes. The missionaries have made it to replace the indigenous Trobriand magic, science, and eschatological belief system by Christian 'magic', 'science' and religion. ${ }^{51}$ This was foreseen a long time

51. Eric Venbrux (personal communication) points out that "the more recent missionary strategy of 'inculturation' (since the last two or three decades of the 20th century) complicates this picture - the idea of planting the Christian message into people's own culture has led many missionaries to emphasize the importance of maintaining the indigenous language(s) 
ago by Sir Hubert Murray, Lieutenant-Governor of Papua, as the following quote from Murray (1925) by Bromilow (1929:284f) illustrates:

Sir Hubert Murray ... has written, 'Thirteen years ago I called attention to the inevitable disappearance of old beliefs and customs in Papua, and I went on to say unless the missionary is there to help him the native is left like a ship without a rudder, and will run a great risk of being wrecked in the sea of an alien civilization'... The missionary gives in Christianity a new interest in life which will take the place of the old system, which must, eventually, almost inevitably, fall into decay.

However, I assume that Sir Hubert Murray would have been very much surprised would he have known that it would take such a long time for this prediction to come true on the Trobriands. ${ }^{52}$

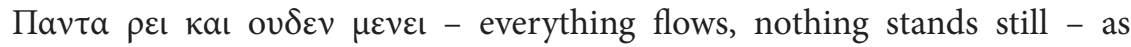
Heraclitus is said to have said. So why lament the loss of these language varieties, the loss of magical formulae and of the wosi milamala, especially given the fact that the Kilivila language as a whole is far from being endangered?

If we look at various specific varieties in our Western-European languages we realize, for example, that former magical formulae and the language variety in which they were written have also died out - I just refer to the two famous Old High German "Merseburger Zaubersprüche" (see Schlosser 1970). However, there is one big difference here: Many of these archaic texts of European languages that document various levels of their historical development were written and therefore could be preserved up to our times. They are documented and thus everybody interested in these texts has access to them. However, for the "biga baloma" variety of Kilivila and the "milamala" songs that are subject of this monograph this was not the case.

It is true that cultures as well as languages are dynamic phenomena - that's the way it is - but our primary task as scientists is to describe and document these dynamics. On a secondary level of our research we may (more or less subjectively) evaluate these dynamics and their results. It is on a completely different and much more political than scientific level, however, that we have the chance to influence the directions of these dynamics - on the basis of our scientific insights, of course.

and cultural heritage." This may well be, however, I could not observe the missionaries' application of this new strategy on the Trobriand Islands.

52. I am not sure, however, whether the missionaries have indeed reduced the risk of indigenous people in Papua "being wrecked in the sea of an alien civilization"... But this is another story and I would like to emphasize that I do not at all want to be misunderstood as sounding paternalistic or post-colonialistic with this aside. 
But as to the scientific level of our argumentation, the facts force us to accept that in all cultures and in all languages we observe dynamic processes that result in cultural and linguistic change. I am determined to observe and describe these dynamic processes that affect the Trobriand Islanders' language and culture in the years to come; however, I also feel obliged to document as many aspects of endangered cultural knowledge as possible that are encoded and manifest in the Trobriand Islanders language in general and in their oral tradition in particular. I hope that this volume will contribute to this aim. 


\section{Appendix $I^{*}$}

\section{Pertinent quotes from}

Frazer, James G. 1913. The belief in immortality and the worship of the dead. Vol. 1.

The belief among the Aborigines of Australia, the Torres Straits Islands, New Guinea and Melanesia. London: Macmillan. [http://www.archive.org/details/ beliefinimmortal00frazuoft].

on the belief in Oceanic cultures in spirits of the dead and in an underworld in which these spirits live. Note the resemblances with Trobriand eschatology!

\section{The Belief in Immortality among the Aborigines of Central Australia}

Pp. $87-126$

p. 92

"... they unanimously believe that death is not the end of all things for the individual, but that the human personality survives, apparently with little change, in the form of a spirit, which may afterwards be reborn as a child into the world. In fact they think that every living person without exception is the reincarnation of a dead person who lived on earth a longer or shorter time ago."

p. 107

"From time to time one of these disembodied spirits enters into a passing woman and is born as an infant into the world."

The Belief in Immortality among the other Aborigines in Australia

Pp. 127-169

p. 127

"...to raise a presumption that a similar belief in the rebirth or reincarnation of the dead was formerly universal among the Australian Aborigines."

p. 128

“... the Aborigines on the Pennefather River think that every person's spirit undergoes a series of reincarnations, and that in the interval between two reincarnations it resides in one or the

* I would like to thank Eva Sauert for her bibliographical help in collecting these quotes while she was a trainee at the MPI for Psycholinguistics. 
other of the haunts of Anjea, a mythical being who causes conception in women by putting mud babies into their bodies."

\section{p. 133}

"In this part of the continent [south-eastern Australia, G.S.] it appears to have often held by the natives that after death the soul is not born again among men, but goes away for ever to some distant country in the sky or beyond the sea, where all the spirits of the dead congregate."

\section{p. 134}

“... the Narrinyeri tribe of South Australia believed that all the dead went up to the sky and that some of them at least became stars ... the dead descend from thence, and walk to the earth..."

\section{p. 138}

“... roam about their old haunts on earth, and communicate with the living ... The Buandik thought that everything in skyland was better than on earth."

\section{p. 139}

"But it was most commonly in dreams that they appear to the living and hold communication with them. Often these communications are believed to be helpful."

\section{p. 140}

“... this savage faith in the reality of dreams has been one of the principle sources of the widespread, almost universal, belief in the survival of the human soul after death."

\section{p. 141}

“... sky-country, where it lives in a land like the earth, only more fertile, better watered, and plentifully supplied with game.”

\section{The Belief in Immortality among the Natives of the Torres Straits Islands}

Pp. 170-189

\section{p. 172}

“... firmly believe in the existence of the human spirit after death ... to depart at last to a distant spirit-land..."

\section{p. 173}

"The word for ghost is mari in the West and mar in the East: it means also shadow or reflection, which seems to show that these savages like many others, have derived their notion of the human soul from the observation of shadows and reflections cast by the body on earth or on water."

\section{p. 174}

"The land of the dead to which the ghosts finally depart is ... a mythical island in the far west or rather north-west. The Western Islanders call it kibu; the Eastern Islanders call it Boigu." 


\section{The Belief in Immortality among the Natives of British New Guinea}

Pp. 190-215

\section{p. 192}

"... spirits of the dead dwell in a happy land ... appear to their friends in dreams ... give them directions for their guidance in time of trouble..."

p. 193

"... human spirit leaves the body at death and goes away to live with other ghosts on a mountain called Idu."

p. 195

“... they punish any neglect in the performance of the funeral rites and any infringement of tribal customs...”

p. 209

"... in this spirit-land eternal youth prevails."

p. 213

"There is no difference between the fate of the good and the fate of the bad in the far country..."

\section{The Belief in Immortality among the Natives of German New Guinea}

Pp. 216-295

\section{p. 224}

“...believe in the existence of the human soul after death ... every soul must pass a ladder to reach the abode of bliss ... The ladder is in the keeping of a spirit called Su asin tjakin'or, the Great Evil, who takes toll of the ghosts before he lets them use his ladder."

p. 228

"When people die their souls go to the land of spirits."

p. 231

"... after death the soul goes to buka kure, which seems to be the village of ghosts."

p. 244

"They do not believe that death is the end of all things for the individual; they think that his soul survives and becomes a spirit or ghost, which they call a balum."

p. 245

"... sometimes the souls of the dead, instead of going away to the spirit land, transmigrate into the body of animals." 
p. 285

“... will naturally bethink himself returning to his long home in the underworld. For sooner or later the spirits of the dead congregate there."

p. 286

"The entrance to the abode of bliss is a cave to the west of Saddle Mountain ... Down below the ghosts are received by Tulmeng, lord of the nether world. Often he appears in a canoe to ferry them over the further shore."

p. 292

"The short soul, on the other hand, never leaves the body in life but only after death. Even then he tarries for a time in the neighbourhood of the body before it takes its departure for Lamboam, which is the abode of the dead in the nether world...

... offerings ... ensure him a friendly reception on his arrival"

The Belief in Immortality among the Natives of German and Dutch New Guinea

Pp. 296-323

p. 299

“... the entrance to it is by a cleft in a rock ... In Lamboam everything is fairer and more perfect than on earth."

The Belief in Immortality among the Natives of Southern Melanesia (New Caledonia) Pp. 324-342

\section{p. $325 f$}

"The souls of the new Caledonians, (...), are supposed to be immortal, at least to survive death for an indefinite period. They all go, good and bad alike, to dwell in a very rich and beautiful country situated at the bottom of the sea, to the north-east of the island of Pott."

p. 326

"It is a country more fair and fertile than tongue can tell. ... At daybreak they revisit their old home on earth..."

The Belief in Immortality among the Natives of Central Melanesia

Pp. 343-392

p. 344

"... all Central Melanesians believe that man is composed of a body and a soul, that death is the final parting of the soul from the body, and that after death the soul continues to exist as a conscious and more or less active being."

p. 345

"... the Melanesians are universally of opinion that ... [the soul] ... survives the death of the body and goes away to some more or less distant region, where the spirits of all the dead 
congregate and continue for the most part to live for an indefinite time, though some of them ... are supposed to die a second death and so to come to an end altogether."

p. 350

"A ship waits to ferry them across the sea to the spirit-land ... at Bugota in the island of Ysabel ... the ghosts of the dead are supposed to go away to an island, and yet to haunt their graves and show themselves to the survivors by night. In the island of the dead there is a pool with a narrow tree-trunk lying across it. Here is stationed Bolafagina, the ghostly lord of the place. Every newly arrived ghost must appear before him, and he examines their hands to see whether they bear the mark of the sacred frigate-bird cut on them; if they have the mark, the ghosts pass across the tree-trunk and mingle with the departed spririts in the world of the dead. But ghosts who have not the mark on their hands are cast into the gulf and perish out of their ghostly life: this is the second death."

\section{p. 355}

"The Eastern Melanesians think that living people can go down to the land of the dead and return alive to the upper world. Sometimes they do this in the body, but at other times only in the spirit, when they are asleep or in a faint; for at such times their souls quit their bodies and can wander away down to Panoi."

\section{The Belief in Immortality among the Natives of Northern and Eastern Melanesia}

Pp. 393-471

\section{p. 395}

"The natives of the archipelago believe that every person is animated by a soul, which survives his death and may afterwards influence the survivors for good or evil."

p. 404

"Sooner or later the souls of all the North Melanesian dead take their departure for the spirit-land ... They call it Matana nion..."

p. 410

"The Fijians believed that man is animated by a soul which quits his body temporarily in sleep and permanently at death, to survive for a longer or shorter time in a disembodied state thereafter."

p. 417

"... the Kayans of Borneo believe in the reincarantion of the soul."

p. 462

"The souls had generally to cross water, either the sea or the river, and they were put across it by a ghostly ferryman."

p. $466 f$.

"Language fails to describe the ineffable bliss of the happy land." 


\section{Appendix II}

For metadata for the films by Irenäus Eibl-Eibesfeldt (E 3129 \& E 3130) see:

Eibl-Eibesfeldt \& Senft (1991).

Metadata for the Wosi Milamala documented on audio- and video-tape

See URL: http://www.mpi.nl/people/senft-gunter/research

Click: Web page for "The Trobriand Islanders' Underworld of Love”

\section{Usi Vekota \& Usi Veponu \& Wosi Dorai}

Audio-tape Tauwema_1982_5II_SideA.wav

Milamala songs - Drums make it difficult to understand the songs

\begin{tabular}{llll}
\hline Name of song & Minutes & Stanza & Chapter \\
\hline Usi Vekota & $00: 20$ & stanza 2 & 3.3 .12 \\
& $02: 25$ & stanza 1 & \\
Usi Veponu & $09: 24$ & stanza 4 & 3.3 .8 \\
Wosi Dorai & 13.00 & stanza 1 & 3.3 .7 \\
& 20.33 & drummer solo till end of tape \\
\hline
\end{tabular}

Usi Veponu \& O Punatina \& Usi Vetoi

Audio-tape Tauwema_1982_3_SideB.wav

Rehearsal of milamala songs, 8.9.1982.

Main singers: Yaurabina, Topia, Bwema'utila

\begin{tabular}{llcl}
\hline Name of song & Minutes & Stanza & Chapter \\
\hline Usi Veponu & $00.00-09.00$ & 3.3 .8 \\
& 00.00 & stanza 3 & \\
& Note: difference in edited transcript and song: \\
& Song: bwetamya kunugu - bwekamya Bweyova \\
& 04.10 & stanza 5 \\
\hline
\end{tabular}

(Continued) 
Main singers: Yaurabina, Topia, Bwema'utila (Continued)

\begin{tabular}{|c|c|c|c|}
\hline \multicolumn{2}{|l|}{ Name of song } & \multirow[t]{2}{*}{ Stanza } & \multirow{2}{*}{$\begin{array}{l}\text { Chapter } \\
3.3 .10\end{array}$} \\
\hline O Punatina & $11.10-24.10$ & & \\
\hline & 11.10 & stanza 1 & \\
\hline & 12.20 & stanza 2 & \\
\hline & 17.40 & stanza 3 & \\
\hline & 23.00 & stanza 4 & \\
\hline \multirow[t]{9}{*}{ Usi Vetoi } & $24.12-38.00$ & & 3.3 .9 \\
\hline & 24.12 & stanza 5 & \\
\hline & 27.12 & stanzas 6 & \\
\hline & 29.30 & stanza 3 & \\
\hline & \multicolumn{3}{|c|}{$\begin{array}{l}\text { Note: } 32.25-33.05 \text { part not transcribed in } \\
\text { between the singing of stanza } 3\end{array}$} \\
\hline & 34.45 & stanza 7 & \\
\hline & 35.50 & stanza 8 & \\
\hline & 37.15 & stanza 1 & \\
\hline & 38.49 & end of ta & \\
\hline
\end{tabular}

Usi Vetoi \& Usi Veponu \& Wosi Dorai

Audio-tape Tauwema_1982_5I_SideA.wav

Milamala songs

\begin{tabular}{llll}
\hline Name of song & Minutes & Stanza & Chapter \\
\hline Usi Veto'i & $00.00-18.10$ & & 3.3 .9 \\
& 01.00 & stanza 1 & \\
& 02.20 & stanza 2 & \\
& 05.10 & stanza 3 & \\
Usi Veponu & $18.10-45.40$ & & 3.3 .8 \\
& 18.10 & stanza 1 & \\
& 24.20 & stanza 2 & \\
& 31.10 & stanza 4 & \\
& 37.40 & stanza 3 (with conch shell) \\
Wosi Dorai & $45.40-$ Ende & stanza 1 & 3.3 .7 \\
\hline
\end{tabular}


Wosi Bwebwe'una \& Bwetadou's dawnce magic

Audio-tape Milamala_1989.wav

Milamala song and milamala dance magic

\begin{tabular}{llll}
\hline Data & Minutes & Stanza & Chapter \\
\hline $\begin{array}{l}\text { Wosi Bwebwe'una } \\
\text { Interview with Yebwaku }\end{array}$ & $00.00-00.41$ & 2 & 3.3 .11 \\
$\begin{array}{l}\text { on homesigns she uses } \\
\text { with her deaf and dumb }\end{array}$ & & \\
$\begin{array}{l}\text { 2 year old daughter: } \\
\begin{array}{l}\text { Tokunupei's Kapisikoya garden } \\
\text { magic (see Senft 1997b): }\end{array}\end{array}$ & $00.42-13.33$ & \\
$\begin{array}{l}\text { Bwetadou's dance magic } \\
\text { 13.45 }\end{array}$ & $15.25-16.05$ & \\
\hline
\end{tabular}

Wosi Bweyava \& Wosi Oluvekoya

Audio-tape WosiMilamalaTodMwasei050697SideA.wav

On the 5th of June 1997 the people of Tauwema sing Wosi Milamala because Mwasei has died.

Main singers: Bulasa, Bwetadou, Mobiliuya, Mokivola, Kalivabu and Kapatu

\begin{tabular}{llcc}
\hline Name of song & Minutes & Stanza & Chapter \\
\hline Wosi Bweyava & $00.00-19.30$ & & 3.3 .1 \\
& 00.00 & 1 & \\
01.45 & 2 & \\
03.35 & 3 & \\
& 05.20 & 4 & \\
06.45 & 5 & \\
& 07.40 & 6 & \\
& 09.15 & 7 & \\
11.20 & 8 & 3.3 .18 \\
13.10 & 9 & \\
Wosi Oluvekoya & $19.40-51.55$ & & \\
& 19.40 & 11 & \\
& 22.35 & 2 & \\
\hline
\end{tabular}


Main singers: Bulasa, Bwetadou, Mobiliuya, Mokivola, Kalivabu and Kapatu (Continued)

\begin{tabular}{|c|c|c|c|}
\hline \multirow[t]{16}{*}{ Name of song } & Minutes & Stanza & Chapter \\
\hline & 24.55 & 3 & \\
\hline & 27.10 & 4 & \\
\hline & 28.20 & 5 & \\
\hline & 30.00 & 6 & \\
\hline & 31.00 & 7 & \\
\hline & 31.55 & 8 & \\
\hline & 34.35 & 9 & \\
\hline & 35.50 & 10 & \\
\hline & 37.45 & 11 & \\
\hline & 40.10 & 12 & \\
\hline & 41.45 & 13 & \\
\hline & 44.40 & 14 & \\
\hline & 46.40 & 15 & \\
\hline & 48.50 & 16 & \\
\hline & 51.05 & 17 & \\
\hline
\end{tabular}

Wosi Doria \& Usi Veponu

Audio-tape Tauwema_1982_3_SideA.wav

(bad quality; gossip between songs)

end of luavala (admonitory speech-by Motaesa) $00.00-01.00$

Rehearsal of milamala songs, 8.09.1982

\begin{tabular}{llll}
\hline Name of song & Minutes & Stanza & Chapter \\
\hline Wosi Dorai & $01.54-34.40$ & & 3.3 .7 \\
& 01.54 & stanza 1 & \\
& 09.35 & stanza 3 & \\
& 15.00 & stanza 6 & \\
& 20.25 & stanza 4 & \\
& $($ see also 26.55) & & \\
& 30.35 & stanza 7 & \\
Usi Veponu & $34.50-48.16$ & & 3.3 .8 \\
& 34.50 & stanza 2 & \\
& 40.25 & stanza 6 & \\
& 46.50 & stanza 3 & \\
\hline
\end{tabular}




\section{Wosi Omnuyobu}

Audio-tape Wosi_Motu_Bwetadou_Milamala_1989_Side A.wav

Seven Songs sung by men in Hiri Motu (Police Motu);

Bwetadou sings the Wosi Omnuyobu

\begin{tabular}{|c|c|c|c|}
\hline Data & Minutes & Stanza & Chapter \\
\hline \multirow[t]{7}{*}{ Motu songs } & $00.00-05.00$ & & \\
\hline & $05.00-07.40$ & & \\
\hline & $07.40-09.20$ & & \\
\hline & $09.20-13.30$ & & \\
\hline & $13.30-16.40$ & & \\
\hline & $16.40-20.00$ & & \\
\hline & $20.00-23.00$ & & \\
\hline \multirow[t]{23}{*}{ Wosi Omnuyobu } & $00.09-07.55$ & & 3.3.2 \\
\hline & 23.10 & 1 & \\
\hline & 24.10 & $2 \mathrm{a}$ & \\
\hline & 25.00 & $2 b$ & \\
\hline & 25.50 & $3 a$ & \\
\hline & 26.40 & $3 b$ & \\
\hline & 27.30 & 4 & \\
\hline & 28.20 & 5 & \\
\hline & 29.40 & 6 & \\
\hline & 30.30 & 7 & \\
\hline & 33.00 & 8 & \\
\hline & 34.50 & 9 & \\
\hline & 36.50 & 10 & \\
\hline & 38.10 & $11 \mathrm{a}$ & \\
\hline & 39.20 & $11 b$ & \\
\hline & 40.10 & 12 & \\
\hline & 41.20 & 13 & \\
\hline & 42.30 & 14 & \\
\hline & 45.00 & 15 & \\
\hline & 46.00 & $17 \mathrm{a}$ & \\
\hline & 48.10 & $17 \mathrm{~b}$ & \\
\hline & 49.00 & 18 & \\
\hline & 50.10 & 19 & \\
\hline
\end{tabular}


122 The Tuma Underworld of Love

Wosi Onegava \& Wosi Pilugwana

Audio-tape Tauwema_1983_T1_Side_A.wav

Milamala songs sung by old women (without drums)

\begin{tabular}{|c|c|c|c|}
\hline Name of song & Minutes & Stanza & Chapter \\
\hline \multirow[t]{22}{*}{ Wosi Onegova } & $00.20-37.55$ & & 3.3 .5 \\
\hline & 00.20 & 4 & \\
\hline & 01.48 & 2 & \\
\hline & 03.04 & 11 & \\
\hline & 05.04 & 10 & \\
\hline & 06.10 & 20 & \\
\hline & 08.04 & 15 & \\
\hline & 09.40 & 5 & \\
\hline & 10.35 & 21 & \\
\hline & 12.20 & 22 & \\
\hline & 15.13 & 1 & \\
\hline & 16.43 & 6 & \\
\hline & 18.15 & 8 & \\
\hline & 20.31 & 16 & \\
\hline & 21.28 & 17 & \\
\hline & 23.02 & 9 & \\
\hline & 25.01 & 14 & \\
\hline & 27.00 & 19 & \\
\hline & 28.22 & 18 & \\
\hline & 31.03 & 3 & \\
\hline & 32.50 & 24 & \\
\hline & 36.04 & 13 & \\
\hline \multirow[t]{4}{*}{ Wosi Pilugwana } & $44.40-51.48$ & & 3.3 .6 \\
\hline & 44.40 & 5 & \\
\hline & 47.55 & 6 & \\
\hline & 49.40 & 1 & \\
\hline
\end{tabular}


Wosi Opesi \& Wosi Oruvekoya \& Wosi Diyapani

Audio-tape WosiMilamalaTodMwasei050697SideB.wav

On the 5th of June 1997 the people of Tauwema sing Wosi Milamala because Mwasei has died.

Main singers: Bulasa, Bwetadou, Mobiliuya, Mokivola, Kalivabu and Kapatu.

\begin{tabular}{|c|c|c|c|}
\hline Name of song & Minutes & Stanza & Chapter \\
\hline \multirow[t]{9}{*}{ Wosi Opesi } & 01:00-19.00 & & 3.3 .19 \\
\hline & 01.00 & 1 & \\
\hline & 02.45 & 2 & \\
\hline & 04.40 & 3 & \\
\hline & 06.55 & 4 & \\
\hline & 09.50 & 5 & \\
\hline & 12.50 & 6 & \\
\hline & 15.25 & 7 & \\
\hline & 17.20 & 8 & \\
\hline \multirow[t]{12}{*}{ Wosi Oruvekoya } & $19.35-42.00$ & & 3.3.3 \\
\hline & 19.35 & 1 & \\
\hline & 20.35 & 2 & \\
\hline & 21.40 & 3 & \\
\hline & 22.45 & 4 & \\
\hline & 24.10 & 5 & \\
\hline & 26.30 & 6 & \\
\hline & 29.25 & 7 & \\
\hline & 34.40 & 8 & \\
\hline & 35.55 & 9 & \\
\hline & 37.00 & 10 & \\
\hline & 39.45 & 11 & \\
\hline \multirow[t]{3}{*}{ Wosi Diyapani } & $43.55-51.15$ & & 3.3.20 \\
\hline & 43.55 & 1 & \\
\hline & 47.40 & 2 & \\
\hline
\end{tabular}


Wosi Pilugwana \& Wosi Onegava

Audio-tape Tauwema_1983_T1_Side_B.wav

Milamala songs sung by old women (without drums)

\begin{tabular}{llcc}
\hline Name of song & Minutes & Stanza & Chapter \\
\hline Wosi Pilugwana & $00.09-07.55$ & & 3.3 .6 \\
& 00.09 & 2 & \\
& $02-33$ & 4 & \\
& $05: 42$ & 3 & \\
Wosi Onegava & $13.00-26.57$ & & 3.3 .5 \\
& 13.00 & 25 & \\
& 15.00 & 7 & \\
& 17.00 & 27 & \\
& 19.17 & 26 & \\
& 21.20 & 23 & \\
& 23.21 & 12 & \\
\hline & & & \\
\hline
\end{tabular}

Wosi Verai \& Wosi Dube’oli \& Wosi Dubeyara

Video-Tape wosimilamala97.mpg

13.06.1997 Bwetadou (at my left, sitting in front of bananas), Bulasa (wearing a green shirt, sitting in front of a canoe prow), Mobiliuya (who came a bit later, wearing a red shirt), Mokeilobu (sitting on the floor between Bulasa and Mobiliuya, wearing a white shirt) and Bomsamwala (sitting on the floor at my right, wearing a white shirt) sing Wosi Milamala after the death of Mwasei.

\begin{tabular}{llcc}
\hline Name of song & Minutes & Stanza & Chapter \\
\hline Wosi verai & $00.25-11.00$ & 5 & 3.3 .4 \\
& 00.25 & 5 & \\
02.05 & 7 \\
03.50 & 8 \\
05.16 & 9 \\
06.05 & 10 \\
& Note: Kaila intertwined with stanza 8 \\
& 06.55 &
\end{tabular}

(Continued) 
13.06.1997 Bwetadou (at my left, sitting in front of bananas), Bulasa (wearing a green shirt, sitting in front of a canoe prow), Mobiliuya (who came a bit later, wearing a red shirt), Mokeilobu (sitting on the floor between Bulasa and Mobiliuya, wearing a white shirt) and Bomsamwala (sitting on the floor at my right, wearing a white shirt) sing Wosi Milamala after the death of Mwasei. (Continued)

\begin{tabular}{|c|c|c|c|}
\hline Name of song & Minutes & Stanza & Chapter \\
\hline \multirow[t]{13}{*}{ Wosi Dube'oli } & $11.06-37.30$ & & 3.3 .16 \\
\hline & 11.06 & 1 & \\
\hline & 12.40 & 2 & \\
\hline & 15.05 & 3 & \\
\hline & 17.05 & 4 & \\
\hline & 18.50 & 5 & \\
\hline & 21.40 & 6 & \\
\hline & 24.25 & 9 & \\
\hline & 26.45 & 12 & \\
\hline & 27.50 & 14 & \\
\hline & 29.20 & 15 & \\
\hline & 31.40 & 16 & \\
\hline & 34.00 & 17 & \\
\hline \multirow[t]{8}{*}{ Wosi Dubeyara } & $37.45-52.30$ & & 3.3.15 \\
\hline & 37.45 & 1 & \\
\hline & 39.15 & 2 & \\
\hline & 40.45 & 3 & \\
\hline & 43.00 & 4 & \\
\hline & 45.40 & 5 & \\
\hline & 47.40 & 6 & \\
\hline & 50.35 & 7 & \\
\hline
\end{tabular}




\section{References}

Aerts, Theodor. 1983. Melanesian gods. Bikmaus IV(2): 1-54.

Baldwin, Bernard. 1945. Usituma! Song of heaven. Oceania XV: 201-238.

Baldwin, Bernard. 1950. Kadaguwai. Songs of the Trobriand sunset isles. Oceania XX: 263-285.

Barton, F.R. 1917. The spirits of the death in the Trobriand Islands. Man 17: 109-110.

Basso, Ellen \& Senft, Gunter. 2009. Introduction. In Ritual Communication, Ellen Basso \& Gunter Senft (eds), 1-19. Oxford: Berg.

Bendann, Effie. 1930. Death Customs: An Analytical Study of Burial Rites. New York NY: Alfred A. Knopf.

Bellamy, R.L. 1908. Notes on the customs of the Trobriand Islanders. Papua Annual Report 1906-7: 63-66.

Bloch, Maurice \& Parry, Jonathan (eds). 1982. Death and the Regeneration of Life. Cambridge: Cambridge University Press.

Bromilow, William E. 1929. Twenty Years among Primitive Papuans. London: The Epworth Press. Chowning, Ann. 1983. Wealth and exchange among the Molina of Fergusson Island. In The Kula: New Perspectives on Massim exchange, Edmund R. Leach \& Jerry W. Leach (eds), 411-427. Cambridge: Cambridge University Press.

Connelly, Andrew James. 2007. Counting Coconuts: Patrol Reports from the Trobriand Islands Part I: 1907-1934. Thesis submitted in partial satisfaction of the requirements for the degree of Master of Arts in Anthropology at California State University, Sacramento. 〈http://www. csus.edu/anth/trobriand/depth/Connelly\%20thesis_Counting\%20Coconuts.pdf〉

Counts, Dorothy A. \& Counts, David R. (eds). 1985. Aging and its Transformations. Pittsburg PA: University of Pittsburg Press.

Crystal, David. 2000. Language Death. Cambridge: Cambridge University Press.

Damon, Frederick H. 1982. Calendars and calendrical rites in the northern side of the Kula ring. Oceania 52: 221-239.

Damon, Frederick H. 1990. From Muyuw to the Trobriands. Transformations along the Northern Side of the Kula Ring. Tucson AZ: The University of Arizona Press.

Damon, Frederick H. \& Wagner, Roy (eds). 1989. Death Rituals and Life in the Societies of the Kula Ring. DeKalb IL: Northern Illinous University Press.

De Revai, M. L., M.D. 1992. Letter to the Editor: Forum Trobriand Islands. National Geographic 182:5, November 1992.

Dutton, Thomas E. 1985. Police Motu: Iena Sivarai (its Story). Port Moresby: University of Papua New Guinea Press.

Eibl-Eibesfeldt, Irenäus. 1981. Humanethologisches Filmarchiv der Max-Planck-Gesellschaft HF 75 Medlpa (Mbowamb) - Neuguinea - Ritual der Totentrauer. Homo 32(1): 59-70.

Eibl-Eibesfeldt, Irenäus \& Senft, Gunter. 1991: Trobriander (Papua-Neuguinea, TrobriandInseln, Kailecuna) Tänze zur Einleitung des Erntefeier-Rituals. Film E 3129. Trobriander (Papua Neuguinea, Trobriand-Inseln, Kiriwina) Ausschnitte aus einem Erntefesttanz. Film E 3130“. Publikationen zu Wissenschaftlichen Filmen. Sektion Ethnologie. 17. (Göttingen: Institut für den Wissenschaftlichen Film IWF). 1-17. 
Feld, Stephen. 1982. Sound and Sentiment: Birds, Weeping, Poetics and Song in Kaluli Expression. Philadelphia PA: University of Pennsylvania Press.

Franklin, Karl J. 1972. A ritual pandanus language of New Guinea. Oceania 43: 66-76.

Frazer, James G. 1912. Anthropological research in northern Australia. Man 12: 72-73.

Frazer, James G. 1913. The Belief in Immortality and the Worship of the Dead, Vol. 1. The Belief among the Aborigines of Australia, the Torres Straits Islands, New Guinea and Melanesia. London: Macmillan. 〈http://www.archive.org/details/beliefinimmortal00frazuoft〉

Gardner, Caroline Hoppe. 1997. The Garden and the Sea: A Reanalysis of Trobriand Cosmology. Thesis submitted in partial satisfaction of the requirements for the degree of Master of Arts in Anthropology at the California State University, Sacramento.

Gillespie, Kirsty. 2010. Steep Slopes - Music and Change in the Highlands of Papua New Guinea. Canberra: ANU E Press 〈http://epress.anu.edu.au/steepslopes_citation.html〉.

Glass, Patrick. 1986. The Trobriand code: An interpretation of Trobriand war shield design. Anthropos 81: 47-63.

Goodenough, Ward H. 1986. Sky world and this world: The place of Kachaw in Micronesia. American Anthropologist 88: 551-568.

Guiart, Jean. 2008. Myth in the islands of the Central Pacific. In Sexual Snakes, Winged Maidens, and Sky Gods. Myth in the Pacific. An Essay in Cultural Transparency, Serge Dunis (ed.), 11-49. Nouméa and Pape'ete: Le Rocher-à-la-Voile and Haere Po.

Habinek, Thomas. 2005. The World of Roman Song: From Ritualized Speech to Social Order. Baltimore MD: Johns Hopkins University Press.

Haddon, Alfred Cort. 1920. Migrations of cultures in British New Guinea. The Journal of the Royal Anthropological Institute of Great Britain and Ireland. 50: 237-280.

Handy, Edward Smith Craighill. 1927. Polynesian Religion. Honolulu HI: Bernice P. Bishop Museum.

Harwood, Frances. 1976. Myth, memory and oral tradition: Cicero in the Trobriands. American Anthropologist 78: 783-796.

Haviland, John. 2009. Little rituals. In Ritual Communication, Ellen Basso \& Gunter Senft (eds), 21-49. Oxford: Berg.

Howes, David. 2003. Sensual Relations. Engaging the Senses in Culture and Social Theory. Ann Arbor MI: The University of Michigan Press.

Ingham, John M. 1996. Oedipality in pragmatic discourse: The Trobriands and Hindu India. Ethos 24: 559-587.

James, Kerry E. 2002. The cost of custom: A recent funeral in Tonga. Journal of the Polynesian Society 111(3): 223-238.

Keck, Verena. 2010. Schwächen des Alters: ein ethnographisches Beispiel aus Mikronesien zur indigenen Rezeption von Demenz. In Lebensqualität bei Demenz? Zum gesellschaftlichen und individuellen Umgang mit einer Grenzsituation im Alter, Andreas Kruse (ed.), 261-278. Heidelberg: Akademische Verlagsgesellschaft.

Keck, Verena \& Wassmann, Jürg. 2010. Das Älterwerden, der Tod und die Erinnerung ein Beispiel aus Melanesien. In Potenziale im Altern. Chancen und Aufgaben für Individuum und Gesellschaft, Andreas Kruse (ed.), 185-200. Heidelberg: Akademische Verlagsanstalt.

Ketobwau, Ignatius Towabu. 1994. Tuma - The Trobriand Heaven - A Study towards the Value of Traditional Trobriand Understanding of Tuma as Heaven. A thesis submitted in partial fulfillment of the requirements for the Bachelor of Divinity (B.D.) degree. Rarongo Theological College Rabaul, Papua New Guinea. 
Kurtz, Stanley. 1991. Polysexualization: A new approach to Oedipus in the Trobriands. Ethos 19: 68-101.

Kurtz, Stanley. 1993. A Trobriand Complex. Ethos 21: 79-103.

Lauer, Peter K. 1970. Amphlett Islands' pottery trade and Kula. Mankind 7: 165-176.

Lauer, Peter K. 1971. Changing patterns of pottery trade to the Trobriand Islands. World Archeology 3(2): 197-209.

Lawton, Ralph. 1997. Buki Pilabumaboma. Kabutubogwa deli Kabutuvau. The Shorter Old Testament and The New Testament in the Language of Kiriwina, Trobriand Islands. Port Moresby: Bible Society of Papua New Guinea.

Layard, John. 1934. The Journey of the dead from the small islands of north-eastern Malekula.

In Essays Presented to C.G. Seligman, Edward Evan Evans-Pritchard, Raymond Firth, Bronislaw Malinowski \& Isaac Schapera (eds), 113-142. London: Kegan Paul, Trench, Trübner \& Co.

Leach, Jerry W. \& Leach, Edmund R. (eds). 1983. The Kula - New Perspectives on Massim Exchange. Cambridge: Cambridge University Press.

Leenhardt, Maurice. 1947. Do kamo. La personne et le mythe dans le monde mélanésien. Paris: Gallimard.

Lithgow, David. 1978. Present trends in Kula at Dobu. Ukarumpa: SIL-paper.

Lorenz, Konrad. 1973. Die Rückseite des Spiegels. Versuch einer Naturgeschichte menschlichen Erkennens. München: Piper (= 1980, München: dtv).

Malinowksi, Bronislaw. 1913. The Family among the Australian Aborigines: A Sociological Study. London: University of London Press.

Malinowski, Bronislaw. 1916. Baloma: The spirits of the dead in the Trobriand Islands. The Journal of the Royal Anthropological Institute of Great Britain and Ireland 46: 353- 430 (= 1974: 149-274).

Malinowski, Bronislaw. 1922. Argonauts of the Western Pacific. London: Routledge \& Kegan Paul (=1978).

Malinowski, Bronislaw. 1925. Magic, science and religion. In Science, Religion and Reality, Joseph Needham (ed.), 19-84. New York: Macmillan (=1974: 17-92).

Malinowski, Bronislaw. 1926a. Myth in Primitive Psychology. London: W. W. Norton \& Co. (= 1974: 93-148).

Malinowski, Bronislaw. 1926b. Crime and Custom in Savage Society. London: Routledge \& Kegan Paul (reprinted 1978).

Malinowski, Bronislaw. 1927. Sex and Repression in Savage Society. London: Routledge.

Malinowski, Bronislaw. 1929. The Sexual Life of Savages in North-Western Melanesia. New York NY: Harcourt, Brace \& World.

Malinowski, Bronislaw. 1932. Myth in primitive psychology [Frazer lecture given on the 27th of November 1925]. In The Frazer Lectures 1922-1932, Warren R. Dawson (ed.), 66-119. London: Macmillan and Co.

Malinowski, Bronislaw. 1935. Coral Gardens and their Magic. Vol. I: The Description of Gardening. Vol. II: The Language of Magic and Gardening. London: George Allen and Unwin.

Malinowski, Bronislaw. 1963a. Science and religion. In Sex, Culture and Myth, Bronislaw Malinowski. 256-267. London: Rupert Hart-Davis. (= 1930).

Malinowski, Bronislaw. 1963b. The life of myth. In. Sex, Culture and Myth, Bronislaw Malinowski. 289-336. London: Rupert Hart-Davis.

Malinowski, Bronislaw. 1967. A Diary in the Strict Sense of the Term. London: Routledge \& Kegan Paul (= 1989) 
Malinowski, Bronislaw. 1974. Magic, Sience and Religion and other Essays. London: Souvenir Press.

Malinowski, Bronislaw. 1992. Malinowski and the Work of Myth. Selected and introduced by Ivan Strenski. Princeton NJ: Princeton University Press.

Marett, Allan. 1992. Variability and stability in Wangga songs from north-west Australia. In Music and Dance of Aboriginal Australia and the South Pacific. The Effects of Documentation on the Living Tradition [Oceania monograph 41], Alice Marshall Moyle (ed.), 193-212. Sydney: University of Sydney.

Marett, Allan. 2000. Ghostly voices: Some observations on song-creation, ceremony and being in northwest Australia. Oceania 71: 18-29.

Marett, Allan. 2002. The tide has gone out on him: Wangga songs, Walakandha dances, and the eternal ebb and flow of existence. Cultural Survival Quarterly 26(2): 22-25. 〈http://www. culturalsurvival.org/print/3984>

Marett, Allan. 2005. Songs, Dreamings, and Ghosts: The Wangga of North Australia. Middletown CT: Wesleyan University Press.

Metcalf, Peter. 1982. A Borneo Journey into Death: Berewan Eschatology from its Rituals. Philadelphia PA: University of Pennsylvania Press.

Metcalf, Peter \& Huntington, Richard. 1991. Celebrations of Death: The Anthropology of Mortuary Rites, 2nd revised edn. Cambridge: Cambridge University Press.

Monberg, Torben. 1991. Bellona Island Beliefs and Rituals. Honolulu: University of Hawai'i press. Montague, Susan. 1971. Trobriand kinship and the virgin birth controversy. Man (N.S.) 6: 353-368.

Montague, Susan. 1974. The Trobriand Society. PhD dissertation, University of Chicago.

Mosko, Mark S. 2009. The fractal yam: Botanical imagery and human agency in the Trobriands. Journal of the Royal Anthropological Institute (N.S.) 15: 679-700.

Mosko, Mark S. 2010. Deep wholes - Fractal holography in Trobriand agency and culture. In Experiments in Holism, Ton Otto \& Nils Bubandt (eds), 150-173). Oxford: Wiley Blackwells.

Moss, Rosalind. 1925. The Life after Death in Oceania and the Malay Archipelago. Oxford: Oxford University Press.

Murray, Hubert. 1925. Papua of To-Day or: An Australian Colony in the Making. London: P.S. King and Son.

Namunu, Simeon. 1984. Spirits in Melanesia and the spirit in Christianity. Religious Movements in Melanesia Today (3) [Point Series No. 4], Glen W. Bays \& Wendey Flannery (eds), 92-95. Goroka: The Melanesian Institute.

Persson, Johnny. 1999. Sagali and the Kula. A Regional System Analysis of the Massim [Lund Monographs in Social Anthropology 7]. Lund: Department of Sociology, Lund University.

Powell, Harry A. 1957. An Analysis of Present Day Social Structure in the Trobriand Islands. Ph.D. dissertation, University of London.

Scheff, Thomas J. 1977. The distancing of emotion in ritual. Current Anthropology 18: 483-505. Schlosser, Horst Dieter (ed.). 1970. Althochdeutsche Literatur. Frankfurt am Main: Fischer.

Scoditti, Giancarlo M.G. 1996. Kitawa Oral Poetry: An Example from Melanesia. Canberra: Pacific Linguistics.

Seligman, Charles Gabriel. 1910. The Melanesians of British New Guinea. With a chapter by F. R. Barton and an Appendix by E. L. Giblin. Cambridge: At the University Press.

Senft, Barbara \& Senft Gunter. 1986. Ninikula-Fadenspiele auf den Trobriand-Inseln, PapuaNeuguinea. Untersuchungen zum Spiele-Repertoire unter besonderer Berücksichtigung der spiel-begleitenden Texte. Baessler-Archiv (NF) 34: 93-235. 
Senft, Gunter. 1985. Trauer auf Trobriand - eine ethnologisch/linguistische Fallstudie. Anthropos 80: 471-492.

Senft, Gunter. 1986. Kilivila - The Language of the Trobriand Islanders. Berlin: Mouton de Gruyter. Senft, Gunter. 1992, As time goes by ...: Changes observed in the Trobriand Islanders' culture and language, Milne Bay Province, Papua New Guinea. In Culture Change, Language Change: Case Studies from Melanesia, Tom Dutton (ed.), 67-89. Canberra: Pacific Linguistics.

Senft, Gunter. 1993. Review of Giancarlo M.G. Scoditti, Kitawa - A linguistic and aesthetic analysis of visual art in Melanesia. Berlin: Mouton de Gruyter, 1990. Journal of Pragmatics 19: 281-294.

Senft, Gunter. 1994. “Darum gehet hin und lehret alle Völker...” - Mission, Kultur- und Sprachwandel am Beispiel der Trobriand-Insulaner von Papua-Neuguinea. In Seelenfischer: Mission, Stammesvölker und Ökologie, Peter Stüben (ed), focus ökozid extra 4: 71-91. Gießen: Focus.

Senft, Gunter. 1995. Notes from the field: Ain't misbehavin'? Trobriand pragmatics and the field researcher's opportunity to put his (or her) foot in it. Oceanic Linguistics 34: 211-226.

Senft, Gunter. 1996. Past is present - present is past: Time and the harvest rituals on the Trobriand Islands. Anthropos 91: 381-389.

Senft, Gunter. 1997a. Bronislaw Kasper Malinowski. In Handbook of Pragmatics: 1997 Installment, Jef Verschueren, Jan-Ola Östman, Jan Blommaert \& Chris Bulcaen (eds), 1-20. Amsterdam: John Benjamins.

Senft, Gunter. 1997b. Magical conversation on the Trobriand Islands. Anthropos 92: 369-391

Senft, Gunter. 1997c. Magic, missionaries and religion. Some observations from the Trobriand Islands. In Cultural Dynamics of Religious Change in Oceania. , Ton Otto \& Ad Borsboom (eds), 45-58. Leiden: KITLV Press.

Senft, Gunter. 2001. Review of the CD Betel Nuts by Christopher Roberts (1996). TMCD 9602. Taipei: Trees Music \& Art, 12-1, Lane 10, Sec. 2, Hsin Yi Rd. Taipei, TAIWAN. Distributed by Sony Music Entertainment (Taiwan)Ltd., 6th fl. No 35, Lane 11, Kwang-Fu N. Rd., Taipei TAIWAN (CD accompanied by a full color bucklet). Kulele 3: 115-122.

Senft, Gunter. 2003. Wosi Milamala - Weisen von Liebe und Tod auf den Trobriand-Inseln. In Anabasis - Prace Ofiarowane Professor Krystynie Pisarkowej, Ireneusz Bobrowski (ed.), 289-295. Kraków: LEXIS.

Senft, Gunter. 2006. A biography in the strict sense of the term. Review article of the book 'Malinowski: Odyssee of an anthropologist 1884-1920, Vol. 1' by Michael Young. Journal of Pragmatics 38: 610-637.

Senft, G. 2007. Reference and 'référence dangereuse' to persons in Kilivila: An overview and a case study. In Person Reference in Interaction: Linguistic, Cultural, and Social Perspectives, Nicholas J. Enfield \& Tanya Stivers (eds), 309-337. Cambridge: Cambridge University Press.

Senft, Gunter. 2008a. The teachings of Tokunupei. In Cultural Styles of Knowledge Transmission. Essays in Honor of Ad Borsboom, Jean Kommers \& Eric Venbrux (eds), 139-144. Amsterdam: aksant.

Senft, Gunter. 2008b. Landscape terms and place names in the Trobriand Islands - The Kaile'una subset. Language Sciences 30(2-3): 340-361.

Senft, Gunter. 2009a. Trobriand Islanders' forms of ritual communication. In Ritual Communication, Gunter Senft \& Ellen B. Basso (eds), 81-101. Oxford: Berg.

Senft, Gunter. 2009b. Bronislaw Kasper Malinowski. In Culture and Language Use. [Handbook of Pragmatics Highlights 2], Gunter Senft, Jan-Ola Östman \& Jef Verschueren (eds), 210-225. Amsterdam: John Benjamins. 
Senft, Gunter. 2009c. "Masawa - bogeokwa si tuta!" - Cultural and Cognitive Implications of Trobriand Islanders' Losing their Knowledge of How to Make a "masawa" Canoe. Invited paper presented at the 8th Interdisciplinary Symposium on Knowledge and Space "Ethnic and Cultural Dimensions of Knowledge" organized by the Department of Geography, University of Heidelberg, supported by the Klaus Tschira Foundation. Heidelberg, Villa Bosch Studio, October 7-10, 2009.

Senft, Gunter. 2010a. The Trobriand Islanders' Ways of Speaking. Berlin: De Gruyter Mouton.

Senft, Gunter. 2010b. Culture change - language change: Missionaries and moribund varieties of Kilivila. In Endangered Austronesian and Aboriginal Australian Languages. Essays on Language Documentation, Archiving and Revitalization, Gunter Senft (ed.), 69-95. Canberra: Pacific Linguistics.

Senft, Gunter. 2011. Expressions for emotions - and inner feelings - in Kilivila, the language of the Trobriand Islanders: A descriptive and methodological critical essay. Nijmegen: Mimeo.

Senft, Gunter \& Basso, Ellen B. (eds). 2009. Ritual Communication. Oxford: Berg.

Spiro, Melford E. 1982. Oedipus in the Trobriands. Chicago IL: The University of Chicago Press Spiro, Melford E. 1992. Oedipus redux. Ethos 20: 385-376.

Sprenger, Guido. 1997. Erotik und Kultur in Melanesien. Eine kritische Analyse von Malinowskis 'The Sexual Life of Savages'. Hamburg: LIT-Verlag.

Stevenson, Robert Louis. 1896. In the South Seas. New introduction by Jeremy Treglown. London: Hogarth Press, Chatto \& Windus. (= 1987).

Stewart, Pamela \& Strathern, Andrew (eds). 2008. Exchange and Sacrifice. Durham NC: Carolina Academic Press.

Stocking, George W. 1973. Contradicting the Doctor: Billy Hancock and the problem of 'baloma'. History of Anthropology Newsletter 4: 4-7.

Stocking, George W. 1986. Anthropology and the science of the irrational: Malinowski's encounter with Freudian psychoanalysis. History of Anthropology 4: 13-49.

Thoma, Ludwig. 1965. Der Münchner im Himmel. In Der Münchner im Himmel. Satiren und Humoresken, Ludwig Thoma, 18-20. München: Deutscher Taschenbuch Verlag.

Trompf, Garry Winston. 1980. Man facing death and rebirth in Melanesia. In Total Cosmic Vision of Life: Introduction to Melanesian Philosophy, Henry Olela (ed.), 138-155. Port Moresby: The University of Papua New Guinea, Department of Psychology and Philosophy. (Originally published 1979 under the title: Man facing death and after-life in Melanesia. In Powers, Plumes and Piglets: Phenomena of Melanesian Religion, Norman C. Habel (ed.), 121-136. Adelaide: Australian Association for the Study of Religion).

Trompf, G.W. 1991. Melanesian Religion. Cambridge: Cambridge University Press.

van Gennep, Arnold. 1909. Les rites de passage. Etude systématique de la porte et du seuil, l'hospitalité, de la grossesse et de l'accouchement, de la naissance, de l'enfance, de la puberté, de l'initiation, de l'ordination, du couronnement, des fiançailles, et du marriage, des funérailles, des saisons etc. Paris: La Haye. ( = The rites of passage. Translated by M. B. Vizedom, G. L. Caffee: Chicago: University of Chicago Press, 1960, reprinted 1969).

Vansina, Jan. 1965. Oral Tradition. Chicago IL: Aldine.

Venbrux, Eric. 1991. A death marriage in a Swiss mountain village. Ethnologia Europaea 21: $145-150$.

Weiner, Annette B. 1976. Women of Value, Men of Renown: New Perspectives in Trobriand Exchange. Austin TX: University of Texas Press.

Weiner, Annette B. 1978. The reproductive model in Trobriand society. Mankind 11: 175-186. 
Weiner, Annette B. 1980. Stability in banana leaves: Colonization and women in Kiriwina, Trobriand Islands. In Women and Colonization, Mona Etienne \& Eleanor Leacock (eds), 270-293. New York NY: J. F. Praeger.

Weiner, Annette B. 1987. Introduction. In The Sexual Life of Savages in North-Western Melanesia, B. Malinowski, xii-xlix. Boston MA: Beacon Press.

Weiner, Annette B. 1988. The Trobrianders of Papua New Guinea. New York NY: Holt, Rinehart \& Winston.

Wieland, Christoph Martin. 1795. Christoph Martin Wielands Sämmtliche Werke. Neunter Band. Musarion, Zweytes Buch. Leipzig Bey Georg Joachim Göschen. ( = C. M. Wieland. 1984. Sämmtliche Werke. Herausgegeben von der Hamburger Stiftung zur Förderung von Wissenschaft und Kultur in Zusammenarbeit mit dem Wieland-Archiv, Biberach/Riß, und Dr. Hans Radspieler, Neu-Ulm. Hamburg. Nördlingen: GRENO).

Young, Michael W. 2004. Malinowski: Odyssee of an Anthropologist 1884-1920, Vol. 1. New Haven CT: Yale University Press. 


\section{Index}

A

adornments 28

Aerts, T. 39

affection 20, 22

aggression 7,8

All Souls Day 41

Alotau 103

armlets XIV, 19, 27, 54, 77

kwasi 19, 54

Australia 35, 36, 40, 44, 103, 111, 112

Australian aboriginals 36

\section{B}

Baldwin, B. 18, 19, 21, 25, 35, $43-47,82,106$

Bartle Bay 38

Barton, F.R. 33

Basso, E.B. 7, 28

Beer, B. IX, 20

behaviour 3, 7, 8, 13, 102, 103

indecent 29, 30, 71, 108

belief XV, XVI, 1, 7-9, 11, $13,15,28,29,31,37$, 38-40, 102, 103, 105, 106-08, 111-115

Bellamy, R.L. 31, 33, 96

Bendann, E. 40

betelnut XIII, 2, 5, 17, 21, 27, $68,69-71,75,76,81$

biga baloma xv, xvI, 25, 41, 43, 44-46, 48, 51, 99, 101, 102, 107-09

Tuma language 9, 25, 43 secret language $25,43,52$

biga megwa 25, 48, 102, 107,108

biga sopa 35

biga tommwaya $\mathrm{xv}, 25,44$, 45, 99

Bloch, M. 40

Bomjamuia 16, 18

Bomsamwala 47, 54, 66, 85, $88,124,125$
Boyowa XVI, 43, 67, 68, 70, 74, 75-77, 84-86

Boyowan 43, 77

Bromilow, W.E. 9, 39, 104, 109

bubwayata 19

Budibudi 62, 63, 83

Bulasa 47, 53, 54, 63, 65, 85, 88, $92,95,97,119,120,123-25$

burial 4-6

Bwetadou 47, 48-50, 53, 54, 59, $60,63-65,82,83,85,88$, $92,95,97,119-21,123-25$

C

cassowary 28, 50, 51

Cerberus 16

Charon 16

chiefs $12,18,23,87-89,93,105$

Chowning, A. 9, 39

clan 1, 4-6, 11, 12, 16, 19, 32, 47, $59,82,89$

dala 4

hierarchy 1,11

coconut oil XIV, 2, 19, 27, 76

conception $21,31,32,34,37,112$

conflict 7, 8, 54, 59

Connelly, A.J. 5, 16, 30, 96

canoe XIII, XV, 12, 15, 48, 62, $63,65,66-70,72,73-75$,

$82,85,86,90,91-94,114$

contraception 33

contraceptives 34,36

corpse $2-6,17$

corpus inscriptionum

Kiriwiniensium 44

Counts, D.A. 7, 72

Counts, D.R. 7,72

crying $2-4,6,18,19,52,55$,

$57,63,68,71,78,80,84$, $85-87,89,91,94$

Crystal, D. 101

culture change 105

culture hero 16

cultural identity 28
Curti, P.A. 38

custom 29, 53, 55, 57, 58, 61, 86, 88,102

\section{D}

\section{dadodiga 27}

daily routines 61,89

Daly tribes 40, 41

Damon, F.H. 1, 7, 9, 29, 38

dance XV, XVII, 3, 21, 27-29, $40,41,45-51,68,71,80,81$, $86,90,98,119$

dancers XIV, 27, 28, 39, 48-50

death XV, XVI, 1-13, 15, 17, $23,24,37,40,63,64$, $66,84,86,88,102,103$, $107,111-115$

cause of $17,31,32$

death watch 6,9

deceased 2-6, 8-10, 12, 17, 23, $24,41,84,86,90,92$

father $3,5,64,68,70,83$, $84,91,95$

mother $3,5,53,54-56$, 58-6o, 65, 68, 70, 82-86, 88,90

siblings 3

widow 3,4

widower 3

decorations 1, 3, 21, 23, 28, 89

D'Entrecasteaux Islands 60

De Revei, M.L. 34

desire 21, 79, 88, 100

Dikumaio'i 17

distribution ceremony $3,7,8$, 10, 93

distribution rituals 6

katukaula 27

puya 3

sagali 3,86

sigiliyawali 7, 8, 10

Dobu 39, 94, 104

drums XIII, XIV, 28, 29, 44,52 
Duna 40

Dutton, T.E. 101

dying $1,2,9,26$

E

earthquake $16,18,19,48,70$

Eibl-Eibesfeldt, I. IX, XI, XVII, $7,28,51,76,79,82,117$

emergence of humans 12

emotions $7,8,13,20,30$

erotic marks 22

eschatology xVI, 9, 15, 37, $38,41,47,102,103,106$, 107,111

eschatological concepts XVI, $15,37,41$

F

feelings 4, 7, 20, 24, 65

Feld, S. 8

Fergusson 39, 54, 60

Finisterre Mountains 40

fragrance $73,77,100$

Franklin, K. 43

Frazer, J. XVII, 35, 36, 38, 40, 111

friendship 54, 92, 94, 96

G

Gardner, C.H. 24

Gawa 12, 95, 96

Gilala 17

Gilela va sopi 18, 60, 79

Gillespie, K. IX, 3, 20

Gionavana 1, 3, 4

Glass, P. 16, 21, 31, 43

Goodenough, W. 40

grave $4-6,8,10,115$

grief $2-5,7-9,18$

Guiart, J. 40

$\mathrm{H}$

Habinek, T. 40

Haddon, A.C. 11

Haiku 73

Handy, E.S.C. 40

Harwood, F. 99

Haviland, J. 28

Heraclitus 109

herbs XIII, XIV, 19, 20, 27, 33,

$53,54,57-61,65,67-81$,

$85,86-88,99,100$

hole $11-13,16,18,38$
Howes, D. 16, 19, 21, 99, 100

Huntington, R. 7, 13

I

inculturation 108

immortality 8, 9, 39, 103, 111-115

Imdeduya 16, 66, 67

Ingham, J.M. 16, 20, 21

J

James, K.E. 7

jealous 30,34

jealousy 30

K

Kaduwaga 86, 90, 92-96

Kaile'una xIII, Xvi, 15, 63, 86, 90, 92, 93, 96

kalibom xv, 30

Kalivabu 53, 63, 92, 95, 97, 119, 120,123

Kapatu 53, 63, 92, 95, 97, 119, 120,123

katayausi 21, 76, 86

Katubai 86, 90

Keck, V. IX, 39, 40

Ketobwau 9, 12, 13, 22

Kiaps 6

Kilivila $\mathrm{x}, \mathrm{XV}, \mathrm{XVI}, 5,7,25$, $30,33,34,43,44-46,48$, $51,59,86,99,101,104$, 108, 109

situational-intentional varieties 44,101

kinsmen 3, 4, 18, 27

Kiriwina XVI, 16, 26, 32, 38, 54, $63,67,70,71,75,77,85,86$, $90,95,103,106,107$

Kitava XVI, 26

Koita 40

Koma 1, 93, 95, 96

Kula xvi, 66, 67, 70, 72, 73, $75,88,94$

Kumilabwaga 19

Kurtz, S. 20, 21, 33

Kwato 38

L

Laba'i 11, 12

language change 108

Lauer, P.K. 6

Lawton, R. 104
Layard, J. 40

Leach, E. 66

Leenhardt, M. 40

Lethe 20

life $\mathrm{xV}, \mathrm{XVI}, 7-9,11-13$, $15-17,21-23,28,31,32$, $38,39,41,44,61,64,89$, 90, 99, 103, 104, 106, 107-09, 114, 115

Lithgow, D. 73

Long Island 40

Lorenz, K. 7

Losuia 95, 96, 101

Louisiade Archipelago 103

love XIII, 4, 19-23, 54, 60-64, $68,70,71-75,77,79-81$,

$89,103,108$

lover $54,64,71,77,79,80,82$, 96, 97

love magic XIII, 19, 20, 48, $54,60,67,71-73,75,77$, $79-81,88,100$

M

Madang 40

magic XIII, 5, 11, 17, 19-21, $25,33,47-51,54,61,66$, $70,82,89,102,103$, 105-08, 119

magical formulae $5,25,34,44$, $47,48,50,107,109$

magician 5, 25, 27, 33, 48, 50, 105-07

Malekula 40

Malinowski, B. XIV, XVI, 1, 2, 4, 5-13, 15-27, 29-37, 43, $44,48,66,82,90,99,100$, 102-106, 133

Marett, A. 40, 41

marriage 4, 6, 22, 27, 34, 66

Marshall Bennets 11, 38

Massim XV, XVI, 9-11, 15, $37-39,82,99,103$

mat $1-3,5,17,29,65,67,77$, 79,81

Melanesia 9, 11, 15, 18, 34, 35, $39,111,114,115,133$

mensis 31

metalinguistic awareness 101

Metcalf, P. 7, 9, 13

midwife 85

milamala festival XVI, 15, 29, $43,86,102$ 
harvest festival xIV, xv, $25-27,44,45,47,52,107$

milamala songs $2,6,9,27,28$, $30,45,49,94,103,106,109$ cycles XVII, 25, 46, 47, 51, 52 intoning XIII, 2, 28, 45, 52 kaila 51, 52-58, 62-66, 69-71, 74, 75, 77, 79, 81, 87, $88,91,93,95,96,98$

meaning $\mathrm{xv}, 45,46,93,94$, 101, 107

melodies XIII, XVII, 28, 45, $46,51,52,98,99$

sequence of stanzas 47,74 , $76,79,81$

special features 46

transcribing and glossing $\mathrm{xv}, 46,52$

tunes 46

mission 103, 104, 106 missionaries 44, 96, 103-09

Mobiliuya $47,53,54,63,65,85$, $88,92,95,97,119$, 120, 123-25

Modawosi stone 16

Mokeilobu 47, 65, 85, 88, 124,125

Mokivola 53, 63, 92, 95, 97, 119, 120,123

Moligala 1

Molina 39

Monberg, T. 40

Montague, S. 33, 86

moral 4, 17, 26, 39, 103-06, 108

Morobe 40

Mosko, M. 24, 37

Moss, R. 5, 6, 9-11, 16, 17, 22,38

Motu 40, 101, 121

mourners $2-4,6,8,9,86$

mourning $\mathrm{xv}, 1,3,4,6-10,27$, $44,45,51,64,66,85,86$, 94-96, 98, 99, 102

mortuary ceremonies $1,6-9$

Moyetukwa 16

Murray, H. 109

Murua XVI, 11

Muyuw XVI, 38

Mwasei 1, 47, 53, 63, 66, 85, 88, $92,95,97,119,123-25$

myth XVI, 8, 11, 12, 15-19, 26, $31,32,34,35,37,66,102$, $103,105,112$
$\mathrm{N}$

Nabwakesa 16

Nada XVI, 11

names $23,48,59,82,85$

Namunu 13, 17, 18, 23, 99

Normanby 39

norms 29, 30

$\mathrm{O}$

Obukula 12

olfaction $77,99,100$

orgy 20,21

$\mathbf{P}$

palolo worm 26

Papuan XVI, 11

Parry, J. 40

paternity $32-36$

perfume 77,79

Perry, W 35

Persson, J. 66

Plato 10

play $57,59,60,69,72$, $73,87-89$

Ponape 40

Port Moresby 92, 93

Powell, H.A. 104

privacy 20

propositioning 60

psychoanalysis 35

\section{R}

rank 1, 11, 12, 82, 104, 105

reincarnation $31-33,38,111$

rejuvenation $23,31,32.40$

religion $7-9,39,40$, $103,106-08$

respect 5,33

rite de passage 9

ritual XIV, $6-8,27,28,45,48$, $102,103,105,107,108$

ritual communication 7,28 ritual cleansing 6 ritualized formulae 3 ritual language 108

Rivers, W.H.R. 35, 48

\section{S}

sadness $46,57,60,64,68,70$, $80,89,91-94,98$

Scheff, T. 7

Schlosser, H.D. 109

schools 101
Scoditti, G. 25, 74, 77

seduction 20, 75

Seligman, C.G. 10, 11, 16-18, $23-25,35,36$

Senft, B. 85

Senft, G. xIV, XVI, XVII, 1-7, $10,16,19,25,26,28,30,33$, 34-36, 44-46, 48, 51, 63, $64,66,70,71,73,74,76$, $79,80,82,83,85,92,101$, $103,108,117,119$

sex $16,18,20-22,25,31,33-36$, $54,89,100$

sexuality $20-22,104,108$ sexual license 30

shipwreck 63, 92-94

skirts xIV, 2, 3, 6, 7, 27, 74-77, $85,86,89,93,108$

smell XIII, 39, 54, 57-59, 61, 63, $65,67,69,72,73,75-77$, $79,80,85-88,99,100$

Smith, E. 35

solidarity 9

Spencer, B. 35,36

spirits of the dead $\mathrm{xV}, \mathrm{xVI}$, $9-13,15,18-22,24-30,32$, $37,39-41,43,44,57,102$, 106, 111, 112-14

spirit child 31,32

baloma xV, XVI, 1, 5, 7-10, $15,33,37,38,41,43,48,103$ chasing away 30 communicate 45 , 101, 112 invisible XVI, 5, 6, 9, $15,17,24,26,29,31$

kosi 9, 10, 40 return to villages $\mathrm{XVI}$, $15,24,102$

visits $23-27,29,41,72$, $84,89,92$

Spiro, M.E. 21, 33

Sprenger, G. 22, 34

sorcerer 105, 106 bwagau 10

sorcery $6,17,103,105$

sorrow 2, 8, 19, 54, 59, 64, $87-89,96$

status $8,9,22,28,43,44,48$, $82,101,105,107$

Stevenson, R.L. 104, 105

Stewart, P. 40

Stocking, G.W. 21, 32, 35 
St. Peter 16

Strathern, A. 40

sulumwoya 19, 54

sympathy 54

$\mathrm{T}$

taboo 2, 4, 19, 21, 22, 77

brother-sister taboo 19, 22,77

Tauwema IX, X, XIII, XV, 1 , $10,16,24,25,29,32,33$, 50, 55, 56, 63, 74, 86,

92, 97, 102, 117, 118-20, 122-24

Tenupanupaia 16

Thoma, L. 107

Tiwi 44

Tobewaga 90

Tok Pisin 101

toliuli 4, 6

toliyouwa 4, 6

Tokunu 11

Tokunupei 16, 31, 119

Topileta XVI, 15, 16-18, 60, 70,79

Torres Strait Islanders 40 totem 12, 39

tradition 2, 102, 103, 110

Trompf, G.W. 7, 9, 29, 38, 39

Truk 40

Tubetube XI

\section{Tudava 16}

Tuma Xv, XvI, 1, 5, 9-13, $15,16-26,32,37,38,43$, 46,107

admission 17

euphemism 70, 79

underworld $\mathrm{xV}, \mathrm{xVI}, 1$, 9-12, 16-18, 21-24, 37, 38

villages XVI, 11, 15, 18, 22, $23,61,89$

$\mathrm{U}$

ulatile 22

underground 11, 12, 16

$\mathrm{V}$

Vakuta XVI, 20, 26

valuables XVI, $2,5-7,17,29,80$ vegua $2,5,17$

vana XIII, 19, 53, 57, 58, 60, 65, $68,69,71,72,74,76,77$, $81,85,87$

van Gennep, A. 7, 9, 13

Vansina, J. 99

Vanuatu 40

Vapalaguyau 33

Venbrux, E. IX, 7, 13, 33, 35-37, 40, 41, 44, 108

veyola 4

virgin birth $33-35,37$

vision 100

\section{W}

Wagner, R. 1, 7, 9

Wamira 38

Wangga 40

Wassman, J. IX, 39

Wedau 38

Weiner, A.B. 1, 4, 6, 7, 9, $27,28,33-35,48,86$, 104, 133

Weltanschauung 106

Weyei 31, 33, 49, 50, 90

Wieland, C.M. 10

Woodlark 12, 38, 66, 67

wooing 21, 75

World War II 16, 95

wreaths of flowers XIII,

$54,59-63,72,73$,

$75-77,81,85,86$,

99, 100

Y

yams xIV, Xv, 6, 24, 27, 29, 30, 37,106

yams-house 2

Yolina 16, 66

Young, M. 1, 6, 22, 23, 30, $33,35,36,60,62-64$, $66,67,70,72,73,86,88$, 91, 92-94, 96, 101, 102, 105,107

Yupno 40 
The Trobriand Islanders' eschatological belief system explains what happens when someone dies. Bronislaw Malinowski described essentials of this eschatology in his articles "Baloma: the Spirits of the Dead in the Trobriand Islands" and "Myth in Primitive Psychology". There he also presented the Trobrianders' belief that a "baloma" can be reborn; he claimed that Trobrianders are unaware of the father's role as genitor. This volume presents a critical review of Malinowski's ethnography of Trobriand eschatology finally settling the "virgin birth" controversy. It also documents the ritualized and highly poetic "wosi milamala" - the harvest festival songs. They are sung in an archaic variety of Kilivila called "biga baloma" - the baloma language. Malinowski briefly refers to these songs but does not mention that they codify many aspects of Trobriand eschatology. The songs are still sung at specific occasions; however, they are now moribund. With these songs Trobriand eschatology will vanish.

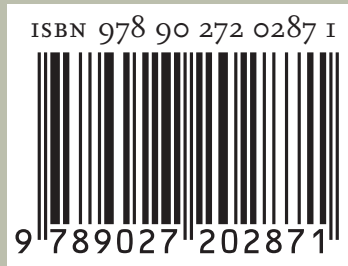

John Benjamins Publishing Company 